\title{
PLASMID TRANSFER IN PLANKTONICALLY-GROWN CULTURES AND BIOFILMS
}

\author{
by \\ Farhana Shamsad \\ Master of Science, Ryerson University 2012 \\ Bachelor of Science, University of Dhaka 2006
}

\author{
A dissertation \\ presented to Ryerson University \\ in partial fulfillment of the \\ requirements for the degree of \\ Doctor of Philosophy \\ in the program \\ of Molecular Science
}

Toronto, Ontario, Canada 2018

(C) Farhana Shamsad 2018 


\section{AUTHOR'S DECLARATION}

I hereby declare that I am the sole author of this dissertation. This is a true copy of the dissertation, including any required final revisions, as accepted by my examiners.

I authorize Ryerson University to lend this dissertation to other institutions or individuals for the purpose of scholarly research.

I further authorize Ryerson University to reproduce this dissertation by photocopying or by other means, in total or in part, at the request of other institutions or individuals for the purpose of scholarly research.

I understand that my dissertation may be made electronically available to the public. 


\title{
PLASMID TRANSFER IN PLANKTONICALLY-GROWN CULTURES AND BIOFILMS
}

\author{
Farhana Shamsad, Doctor of Philosophy, Molecular Science \\ Ryerson University, 2018
}

\begin{abstract}
Conjugation of plasmids is widespread among bacteria and contributes to the spread of antibiotic resistance. In the natural environment, microorganisms predominantly exist in the form of biofilms or other bioaggregates, where they may be exposed to contaminants such as antibiotics, at subinhibitory concentrations. Bacterial cells in older biofilms have lower growth activity due to oxygen and nutrient limitation in the deeper layers of the biofilms. In batch culture, population growth eventually ceases during the stationary phase. Thus, the steady state of biofilms may resemble stationary growth phase cultures. Our objectives were to study (i) the effect of cell growth phases and (ii) subinhibitory and minimum inhibitory concentrations (MIC) of antibiotics on transconjugant formation in both batch cultures and biofilms. Additionally, (iii) the effect of variable nutrient concentrations on MIC was investigated and (iv) an optimization of RT-PCR method for the detection of traA gene (which encodes pilus biosynthesis) expression was carried out.

To study the effect of cell growth phases on transconjugant formation, plate matings were carried out utilizing planktonic cultures grown to exponential or stationary phase of donor and recipient strains. The results showed that transconjugant abundance was the highest $(20 \pm 0.08 \%)$ when both plasmid donor and recipient cells were grown to the stationary phase. However, the growth phase of the donor did not seem to play a role in biofilms. When donor cells were harvested from either the exponential or stationary phase of growth, and inoculated into $24 \mathrm{~h}$ old recipient
\end{abstract}


biofilms, there was no statistically significant difference between transconjugant abundance. A higher percentage of transconjugants was detected in plate matings when the donor was exposed to $0.5 \times$ minimum inhibitory concentration of gentamicin and additionally challenged with gentamicin at MIC. In biofilms, transconjugant formation was not enhanced when the donor cells were grown with $0.5 \times$ MIC gentamicin, and $0.5 \times$ MIC gentamicin was added to the biofilms. A decrease in nutrient concentration was associated with a decrease in the MIC. $\operatorname{traA}$ expression, detected using RT-PCR in plasmid donor cells grown to early exponential and late exponential phases did not coincide with an increase in transconjugants. 


\section{ACKNOWLEDGEMENTS}

I am very grateful to my supervisor Dr. Martina Hausner who was a tremendous mentor. I would like to thank you for your patience, guidance and continuous support. I would also like to thank my committee members Dr. Kimberly Gilbride, Dr. Celine Levesque, and Dr. Gideon Wolfaardt for your critical insights and suggestions. I would like to thank all of my volunteers; Sujeev Sithamparanathan, Zuhra Omary, Manaum Zain, Syed Ibrahim, Hussein Hamam, Tehreem Khan, Hillian James and lab member Spencer Crook. I would like to thank all of the Gilbride and Wolfaardt lab members for their friendship, support, and help. I would also like to thank Dr. Delphine Dufour for her suggestions to troubleshoot RT-PCR.

Lastly, thank you to my family for all your support. 


\section{Table of Contents}

AUTHOR'S DECLARATION ....................................................................................... ii

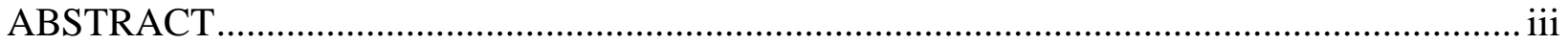

ACKNOWLEDGEMENTS ..........................................................................................

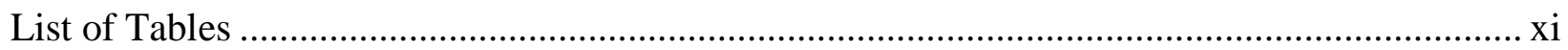

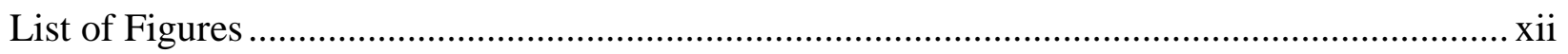

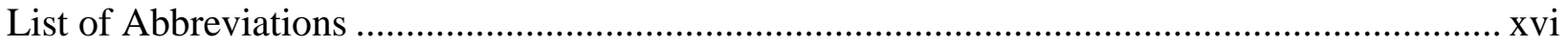

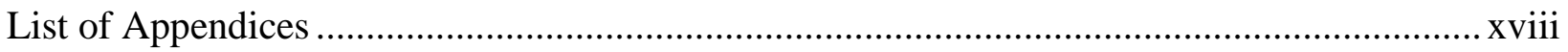

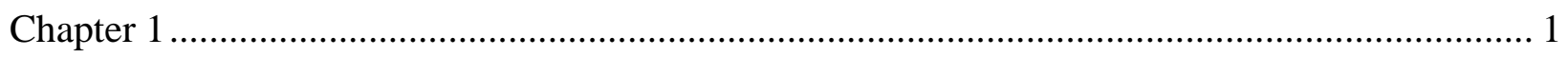

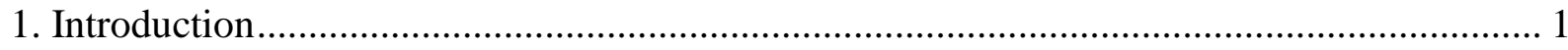

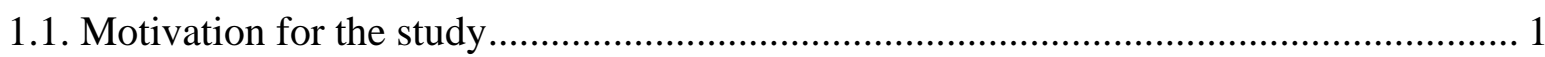

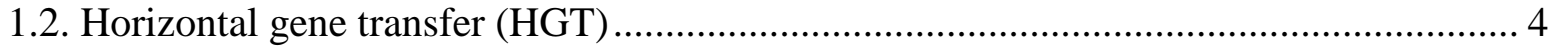

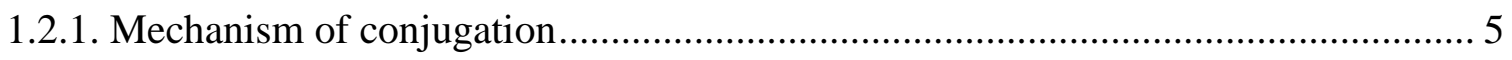

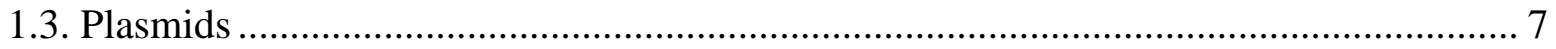

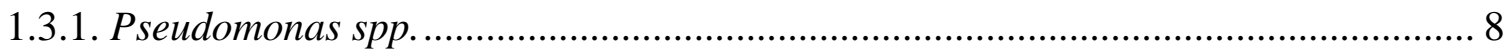

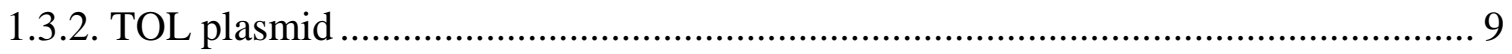

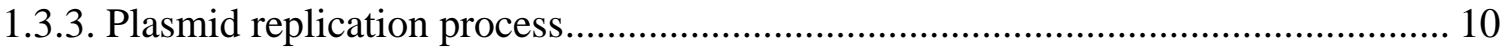

1.3.4. Role of plasmid donor and recipient in conjugation ....................................... 11

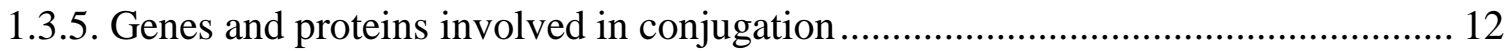

1.3.6. Regulatory processes influencing conjugation and expression of genes in

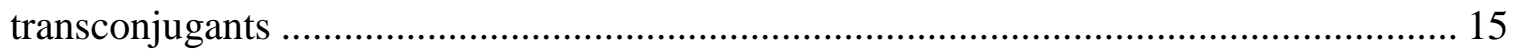

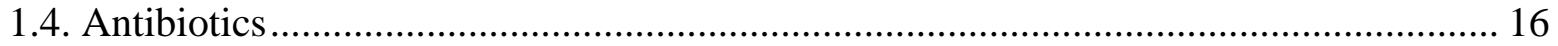


1.4.1. Subinhibitory concentrations of antibiotics act as signalling molecules, mechanisms of signalling molecules

1.4.2. Minimum inhibitory concentration (MIC), Minimum bactericidal concentration

(MBC), Minimum biofilm eradication concentration (MBEC) 18

1.4.3. Aminoglycoside antibiotics: usage, toxicity ............................................... 19

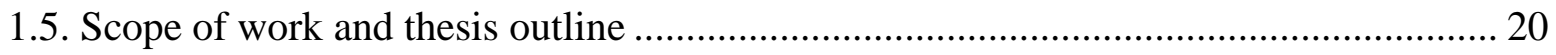

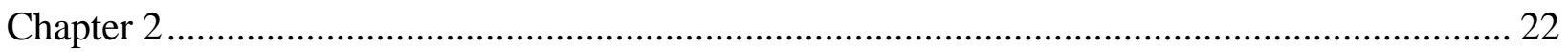

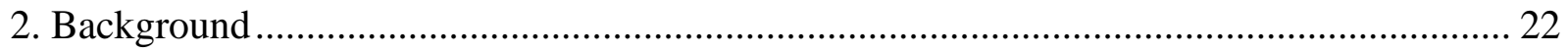

2.1. Project 1: Effect of cell growth phases on transconjugant formation in plate matings and

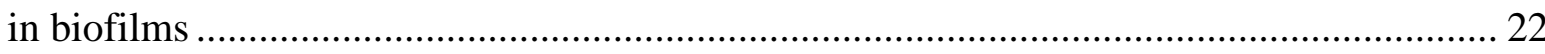

2.2. Project 2: Optimization of RT-PCR to detect expression of $t r a A$ in plasmid donor cells 25

2.3. Project 3: Effect of nutrient concentrations on the determination of minimum inhibitory

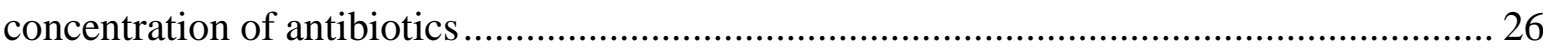

2.4. Project 4: The effects of subinhibitory and minimum inhibitory concentrations of gentamicin on transconjugant formation in plate matings and biofilms ......................... 29

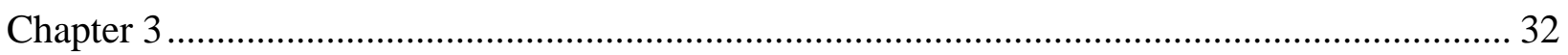

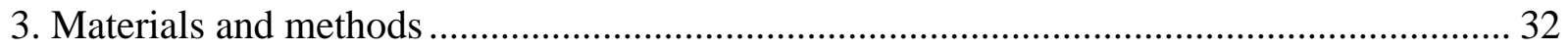

3.1. Effect of cell growth phases on transconjugant formation using planktonic cultures and

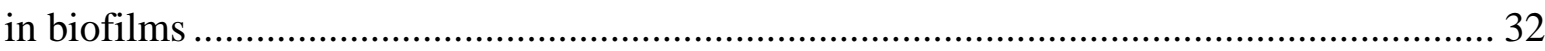

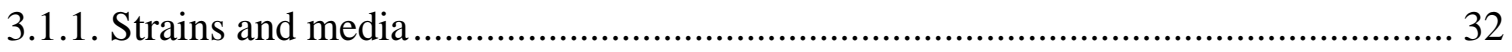

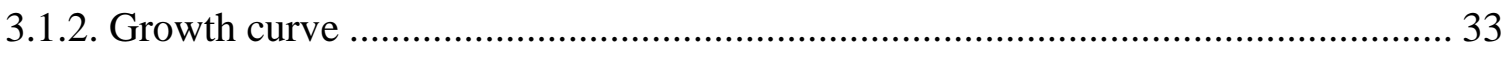

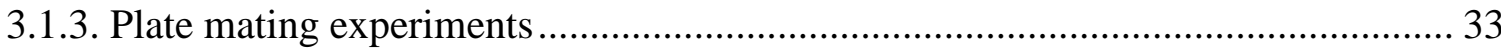




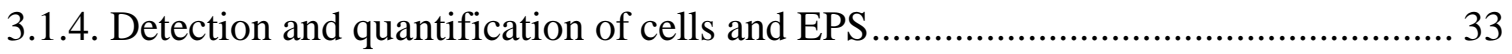

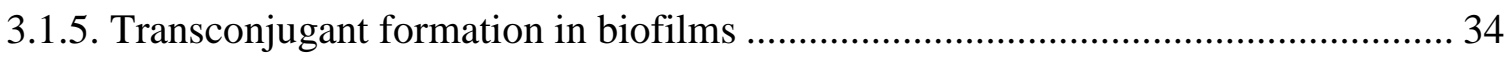

3.1.6. Cell size measurement at different growth phases ......................................... 35

3.1.7. DNA extraction, primers and polymerase chain reactions (PCR) ....................... 35

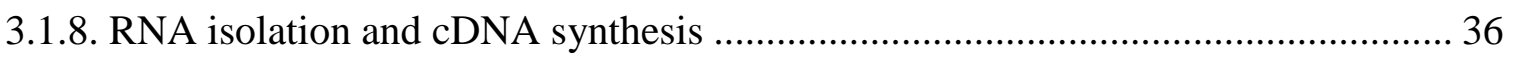

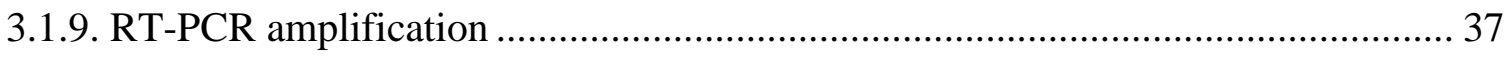

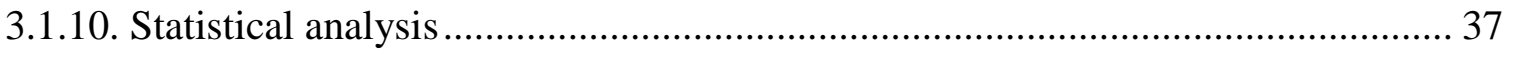

3.2. Optimization of RT-PCR to detect expression of $\operatorname{traA}$ in plasmid donor cells............. 38

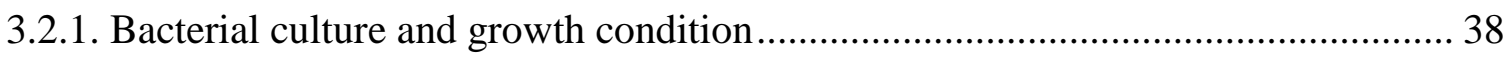

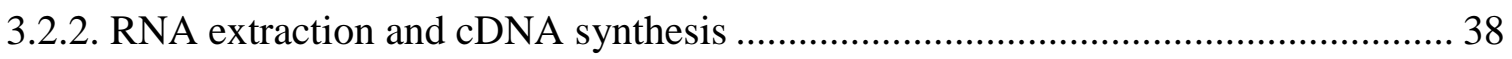

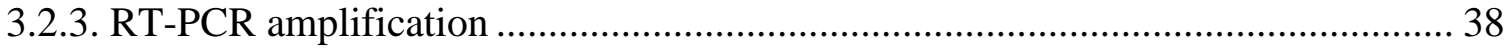

3.3. Effect of nutrient concentrations on the determination of minimum inhibitory

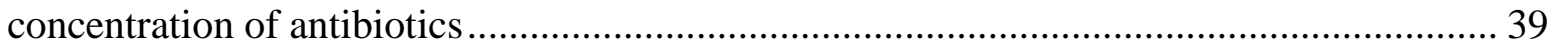

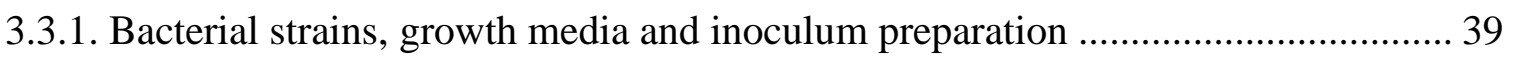

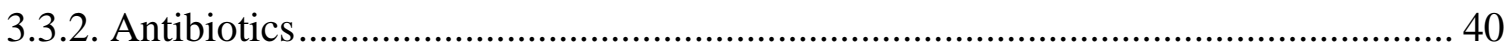

3.3.3. Determination of the minimal inhibitory concentration (MIC) ........................... 40

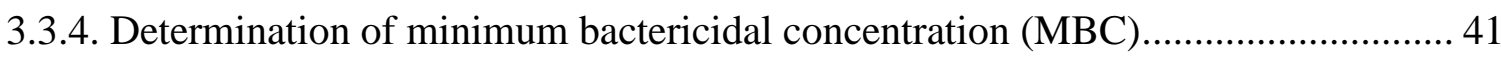

3.3.5. Determination of minimum biofilm eradication concentration (MBEC) .............. 42

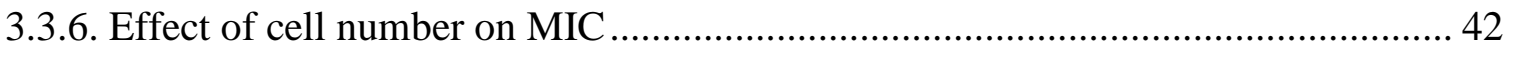

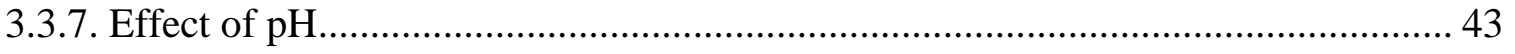

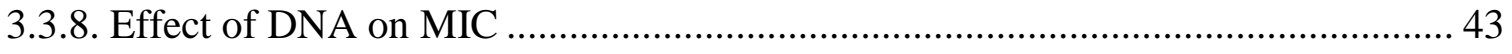

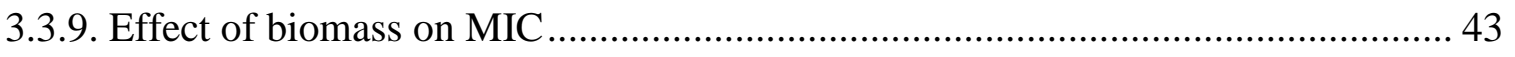


3.4. The effects of subinhibitory and minimum inhibitory concentrations of gentamicin on transconjugant formation in biofilms and plate matings.................................................. 44

3.4.1. Bacteria strains and growth conditions ………………..................................... 44

3.4.2. Plasmid transfer in plate mating experiments in the presence of gentamicin......... 44

3.4.3. Plasmid transfer in biofilms in the presence of gentamicin (in 24 well plates) ...... 45

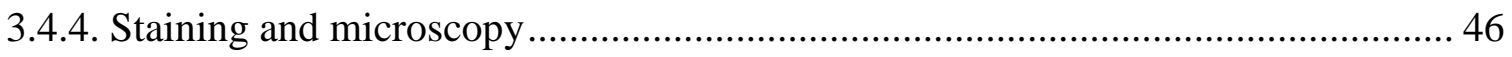

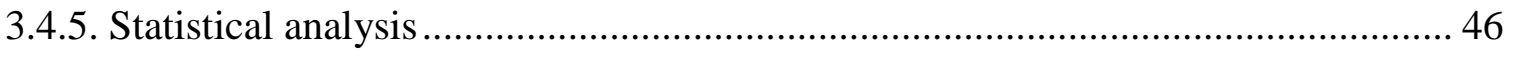

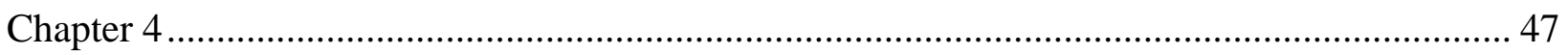

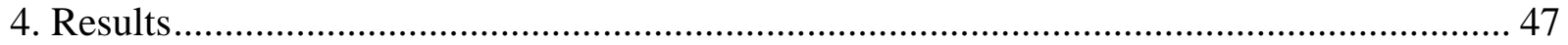

4.1. Effect of cell growth phases on transconjugant formation using planktonic cultures and

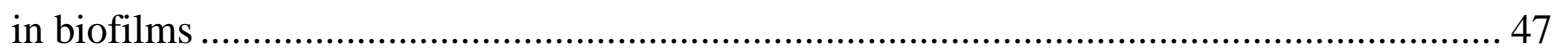

4.1.1. Effect of cell growth phases on plasmid transfer in plate matings using

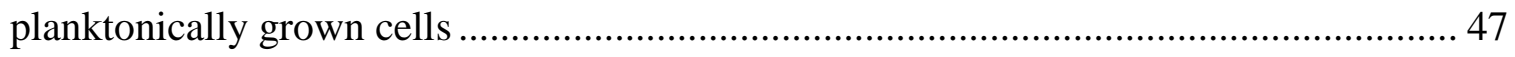

4.1.2. Effect of plasmid donor growth phases on plasmid transfer in biofilms ................ 57

4.2. Optimization of RT-PCR to detect expression of traA in plasmid donor cells...............58

4.3. Effect of nutrient concentrations on the determination of minimum inhibitory

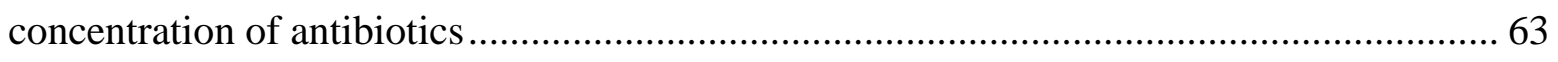

4.4. The effects of subinhibitory and minimum inhibitory concentrations of gentamicin on

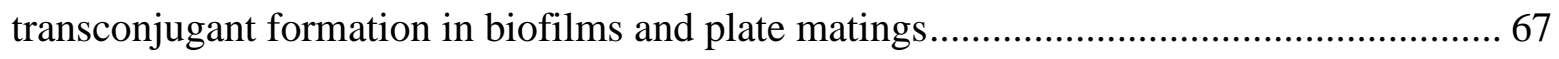

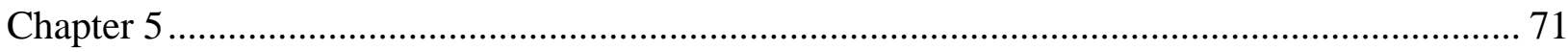

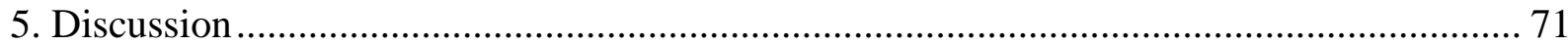

5.1. Effect of cell growth phases on transconjugant formation using planktonic cultures and

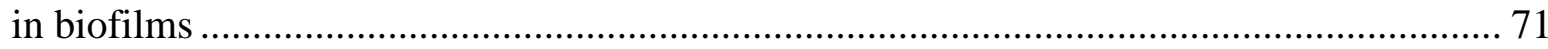


5.1.1. Effect of cell growth phases on plasmid transfer in plate matings using planktonically grown cells

5.1.2. Effect of plasmid donor growth phases on plasmid transfer in biofilms ............... 75

5.2. Optimization of RT-PCR to detect expression of $\operatorname{traA}$ in plasmid donor cells............. 76

5.3. Effect of nutrient concentrations on the determination of minimum inhibitory

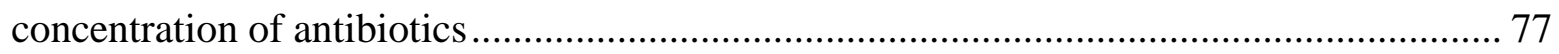

5.4. The effects of subinhibitory and minimum inhibitory concentrations of gentamicin on transconjugant formation in biofilms and plate matings.......................................... 81

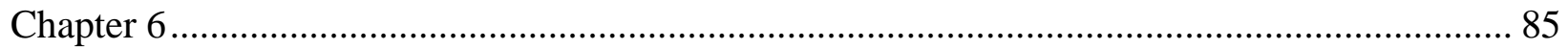

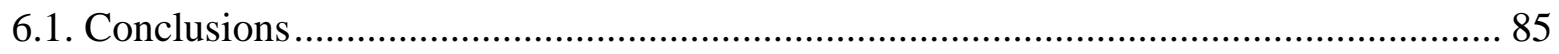

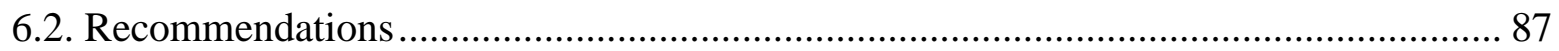

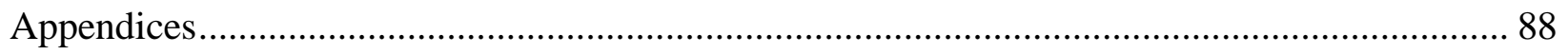

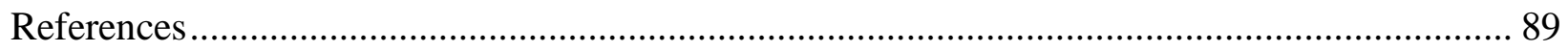




\section{List of Tables}

Table 1.1. Transfer region genes involved in plasmid transfer during conjugation (adapted from

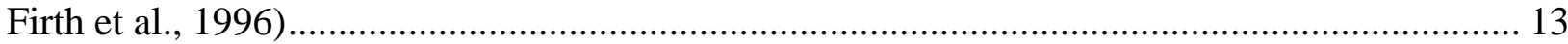

Table 4.1. Transconjugants in mating patches as a percentage of total cells..............................50

Table 4.2. Average cell size at exponential and stationary growth phases of $P$. putida ATCC12633 and $P$. putida BBC443.

Table 4.3. Determination of MIC of kanamycin (kan), gentamicin (gen), tetracycline (tet), and rifampicin (rif) for $P$. putida $\mathrm{BBC} 443$ and $P$. putida ATCC12633 with varying nutrient concentrations.

Table 4.4. Effect of different cell numbers on minimum inhibitory concentration of gentamicin for $P$. putida BBC443 with varying nutrient concentrations.

Table 4.5. $\mathrm{pH}$ at minimum inhibitory concentrations of gentamicin for $P$. putida $\mathrm{BBC} 443$ with different cell numbers.

Table 4.6. $\mathrm{pH}$ at $0.5 \times$ or near $0.5 \times$ minimum inhibitory concentrations of gentamicin for $P$. putida $\mathrm{BBC} 443$ with different cell numbers.

Table 4.7. Effect of extracellular DNA at either the MIC or above MIC of gentamicin for $P$. putida BBC443. $10^{3}$ or $10^{5} \mathrm{CFU} / \mathrm{mL}$ were used as inocula and $10 \% \mathrm{LB}$ was used as growth medium. 66

Table 4.8. Effect of biomass at either the MIC or above MIC of gentamicin for P. putida BBC443. $10^{3}$ or $10^{5} \mathrm{CFU} / \mathrm{mL}$ were used as inocula and $10 \% \mathrm{LB}$ was used as medium.............. 66

Table 4.9. Effect of gentamicin on transconjugant formation in plate mating experiment.......... 67

Table 4.10. Effect of $0.5 \times$ MIC of gentamicin on transconjugant formation in biofilms............ 69

Table 4.11. Effect of MIC of gentamicin on transconjugant formation in biofilms. ................... 70 


\section{List of Figures}

Figure 1.1. Mechanisms of horizontal gene transfer (HGT) (adapted from Stewart, 2013)......... 4

Figure 1.2. Rolling circle replication mechanism (adapted from Willey et al., 2011). 11

Figure 1.3. Genetic map of plasmid pWWO. Light green colour (in red box) represents proteins involved in conjugative transfer (From Greated et al., 2002)............................................. 14

Figure 2.1. Steps involved in detection of gene expression using RT-PCR .......................... 26

Figure 4.1. Growth curve of the plasmid recipient strain Pseudomonas putida ATCC12633. Optical density reading was obtained at $600 \mathrm{~nm}$ wavelength. 48

Figure 4.2. Growth curve of the plasmid donor strain Pseudomonas putida BBC443. Optical density reading was obtained at $600 \mathrm{~nm}$ wavelength 48

Figure 4.3. Microscopic image of plasmid donor Pseudomonas putida BBC443 cells. Donor contains the $\operatorname{lacl}^{q}$ repressor gene on its chromosome, which represses the expression of green fluorescence in donor cells. 49

Figure 4.4. Microscopic images of plate mating patch of planktonically grown cultures (donor and recipient cells were grown to early exponential growth phase). (A) All cells were visualized with Syto 62 (blue), (B) EPS bound Con A-TRITC (red), (C) Transconjugants express GFP (green), (D) Overlay of all images 51

Figure 4.5. Microscopic images of plate mating patch of planktonically grown cultures (donor and recipient cells were grown to late stationary growth phase). (A) All cells were visualized with Syto 62 (blue), (B) EPS bound Con A-TRITC (red), (C) Transconjugants express GFP (green), (D) Overlay of all images....

Figure 4.6. Data represent transconjugants expressed as a percentage of all cells for batch culture experiments. Condition A: plasmid donor and recipient cells were grown to early exponential phase, condition B: plasmid donor and recipient cells were grown to late stationary phase, condition $\mathrm{C}$ : plasmid donor cells were grown to early exponential phase and recipient cells were grown to late stationary phase, condition $\mathrm{D}$ : plasmid donor cells were grown to late stationary phase and recipient cells were grown to early exponential phase. Statistically significant groups are marked as $*$ 52

Figure 4.7. Microscopic image of planktonically grown donor cells to late stationary growth phase. Cells were stained with Syto 62 and Con A-TRITC. (A) All cells were visualized with Syto 62 (blue), (B) EPS bound ConA-TRITC (red), (C) Overlay of all images.

Figure 4.8. Microscopic image of planktonically grown donor cells to early exponential growth phase. Cells were stained with Syto 62 and ConA-TRITC. All cells were visualized with Syto 62 (blue), (B) EPS bound ConA-TRITC (red), (C) Overlay of all images. 53 
Figure 4.9. Microscopic images of plasmid donor and recipient cells grown to different growth phases. Cells were stained with Syto 62 (blue). (A) Donor cells grown to early exponential phase, (B) Donor cells grown to late stationary phase (C), Recipient cells grown to early exponential phase, (D) Recipient cells grown to late stationary phase.................................... 54

Figure 4.10. Agarose gel showing PCR-products of the traA gene (200 bp) Lane 1: marker, lane 2: positive control (PCR product for DNA extracted from donor strain P. putida BBC443 overnight culture), lane 3: PCR product for DNA extracted from donor strain $P$. putida BBC443 grown to early exponential growth phase, lane 4: PCR product for DNA extracted from donor strain $P$. putida BBC443 grown to late stationary growth phase, lane 5: negative control (PCR product for DNA extracted from recipient strain $P$. putida ATCC12633 overnight culture)...... 55

Figure 4.11. Gel electrophoresis for RT-PCR products (with $16 \mathrm{~S}$ rRNA primers). RNA was extracted and cDNA was synthesized for donor cells harvested from different growth phases. Lane M: marker, lane 1: positive control (DNA), lanes 2 and 3: donor early exponential phase $(6.5 \mathrm{~h})$, lanes 4 and 5: donor $48 \mathrm{~h}$, lanes 6 and 7: donor late stationary phase $(144 \mathrm{~h})$, lane 8: negative control (cDNA reagents). Expected product size was 200 bp................................... 56

Figure 4.12. Gel electrophoresis for RT-PCR products (with traA primers). RNA was extracted and cDNA was synthesized for donor cells harvested from different growth phases. Lane M: marker, lane 1: positive control (DNA), lanes 2 and 3: donor early exponential phase (6.5 h), lanes 4 and 5: donor 48 h, lanes 6 and 7: donor late stationary phase (144 h), lane 8: negative control (cDNA reagents). Expected product size was $200 \mathrm{bp}$. 56

Figure 4.13. Gel electrophoresis for no RT control samples (with $16 \mathrm{~S}$ rRNA primers). RNA was extracted and cDNA was synthesized for donor cells harvested from different growth phases without RT enzyme. Lane M: marker, lane 1: negative control (water as template), lanes 2 and 3: donor exponential phase $(6.5 \mathrm{~h})$, lanes 4 and 5: donor $48 \mathrm{~h}$, lanes 6 and 7: donor late stationary phase $(144 \mathrm{~h})$. 57

Figure 4.14. Gel electrophoresis for no RT control samples (traA primers). RNA was extracted and cDNA was synthesized for donor cells harvested from different growth phases without RT enzyme. Lane M: marker, lane 1: negative control (water as template), lanes 2 and 3: donor exponential phase $(6.5 \mathrm{~h})$, lanes 4 and 5: donor $48 \mathrm{~h}$, lanes 6 and 7: donor late stationary phase (144 h) 57

Figure 4.15. Microscopic image of transconjugants in recipient biofilms after plasmid donor cells grown to early exponential growth phase were added to $24 \mathrm{~h}$ old plasmid recipient biofilms. Image was taken after $72 \mathrm{~h}$ of donor cells addition. (A) All cells were visualized with Syto 62 (blue), (B) Transconjugants express GFP (green), (C) Overlay of all images. 58

Figure 4.16. Microscopic image of transconjugants in the recipient biofilms after plasmid donor cells grown to late stationary growth phase were added to $24 \mathrm{~h}$ old plasmid recipient biofilms. Image was taken after $72 \mathrm{~h}$ of donor cells addition. (A) All cells were visualized with Syto 62 (blue), (B) Transconjugants express GFP (green) (C) Overlay of all images. 58

Figure 4.17. Gel electrophoresis for RNA samples. RNA was extracted from different growth phases of $P$. putida BBC443 donor cells. Illustra RNA spin mini kit from GE healthcare life 
sciences was used to extract RNA. Lane M: marker $(1 \mathrm{~kb})$, lanes 1-4: RNA was extracted from donor cells grown to early exponential phase (6.5 h, OD 0.6), lanes 5-7: RNA was extracted from donor cells grown to $24 \mathrm{~h}$, lane 8: negative control (H2O, no RNA). 59

Figure 4.18. Gel electrophoresis for RNA samples. RNA was extracted from different growth phases of $P$. putida BBC443 cells. Illustra RNA spin mini kit from GE healthcare life sciences was used to extract RNA. Lane M: marker $(1 \mathrm{~kb})$, lane 1: RNA was extracted from donor cells grown to $72 \mathrm{~h}$, lanes 2 and 3: RNA was extracted from donor cells grown to stationary phase (day 6). 59

Figure 4.19. Gel electrophoresis for RT-PCR products. RT-PCR with cDNA (16S rRNA primers). RNA was extracted and cDNA was synthesized for donor cells harvested from different growth phases. Lane M: marker (100 bp), lane 1: positive control, lane 2: donor early exponential phase, lane 3: donor $24 \mathrm{~h}$, lane 4: donor $72 \mathrm{~h}$, lane 5: donor late stationary phase (day 6), lane 6: negative control (PCR reagents + cDNA reagents), lane 7: negative control (PCR reagents+ MiliQ water). 60

Figure 4.20. Gel electrophoresis for RT-PCR products. RT-PCR with cDNA (with traA primers) to detect the expression of $\operatorname{traA}$ in donor cells at different growth phases. RNA was extracted and cDNA was synthesized for donor cells harvested from different growth phases. Lane M: marker (100 bp), lane 1: positive control, lane 2: donor early exponential phase, lane 3: donor $24 \mathrm{~h}$, lane 4: donor $72 \mathrm{~h}$, lane 5: donor late stationary phase (day 6), lane 6: negative control (PCR reagents + cDNA reagents), lane 7: negative control (PCR reagents+ MiliQ water).

Figure 4.21. Gel electrophoresis for RNA samples. RNA was extracted from P. putida BBC443 donor cells grown to different growth phases. Lane $\mathrm{M}$ : marker (1 kb), lanes 1-3: donor RNA extracted from early exponential phase $(6.5 \mathrm{~h}$, OD 0.6$)$, lanes 4-6: RNA extracted from donor cells grown to $48 \mathrm{~h}$, lanes 7-9: RNA was extracted from donor cells grown to late stationary phase (day 6). 62

Figure 4.22. Gel electrophoresis for gradient PCR products. Gradient PCR with P. putida BBC443 colony cells. traA primers were used. Lane M: marker (100 bp), lane 1: annealing temperature $53^{\circ} \mathrm{C}$, lane 2: annealing temperature $54.25^{\circ} \mathrm{C}$, lane 3: annealing temperature $55.5^{\circ}$ $\mathrm{C}$, lane 4: annealing temperature $56.75^{\circ} \mathrm{C}$, lane 5 : annealing temperature $58^{\circ} \mathrm{C}$, lane 6 : annealing temperature $59.25^{\circ} \mathrm{C}$, lane 7 : annealing temperature $60.5^{\circ} \mathrm{C}$, lane 8: annealing temperature $63^{\circ}$ $\mathrm{C}$, lanes 9-11: negative control $(\mathrm{H} 2 \mathrm{O})$ at annealing temperatures $53^{\circ} \mathrm{C}, 55.5^{\circ} \mathrm{C}, 58^{\circ} \mathrm{C}$. 62

Figure 4.23. Gel electrophoresis for gradient PCR products. Gradient PCR with P. putida BBC443 DNA. traA primers were used. Left lane: marker (100 bp), lane 1: annealing temperature $53^{\circ} \mathrm{C}$, lane 2: annealing temperature $54.25^{\circ} \mathrm{C}$, lane 3: annealing temperature $55.3^{\circ}$ $\mathrm{C}$, lane 4: annealing temperature $56.75^{\circ} \mathrm{C}$, lane 5 : annealing temperature $58^{\circ} \mathrm{C}$, lane 6 : annealing temperature $59.25^{\circ} \mathrm{C}$, lane 7: plasmid recipient DNA as negative control at annealing temperature $55.5^{\circ} \mathrm{C}$. 63

Figure 4.24. Data represent transconjugants expressed as percentage in total cells for batch culture experiments. Condition A: donor cells were not exposed to gentamicin and gentamicin was not added to the plate on which matings were carried out, condition B: donor cells were 
grown with $0.5 \times$ MIC gentamicin for $48 \mathrm{~h}$ and gentamicin was not added to the plate on which matings were carried out, condition C: donor cells were grown with $0.5 \times \mathrm{MIC}$ gentamicin for 48 $\mathrm{h}$ and $0.5 \times$ MIC gentamicin was added to the plate on which matings were carried out, condition D: donor cells were grown with $0.5 \times$ MIC gentamicin for $48 \mathrm{~h}$, additionally challenged with MIC gentamicin for $1 \mathrm{~h}$ and MIC gentamicin was added to the plate on which matings were carried out, condition E: donor cells were not exposed to gentamicin and $0.5 \times$ MIC gentamicin was added to plate on which matings were carried out, condition F: donor cells were grown with $0.5 \times$ MIC gentamicin for $48 \mathrm{~h}$, additionally challenged with MIC gentamicin for $1 \mathrm{~h}$ and gentamicin was not added to the plate on which matings were carried out. Statistically significant group is marked as *.

Figure 4.25. Data represent transconjugants expressed as percentage in total cells for biofilm experiments. Condition A: donor cells were not exposed to gentamicin and gentamicin was not added in the biofilms, condition B: donor cells were grown with $0.5 \times$ MIC gentamicin for $48 \mathrm{~h}$ and $0.5 \times$ MIC gentamicin was added in the biofilms, condition C: donor cells were grown with $0.5 \times$ MIC gentamicin for $48 \mathrm{~h}$ and no gentamicin was added in the biofilms. Statistically significant group is marked as *.

Figure 4.26. Microscopic images of biofilm cells exposed to MIC of gentamicin (A) and without exposure to gentamicin (B). Green cells represent transconjugant cells, red cells represent total cells. (63× magnification was used). 70 


\section{List of Abbreviations}

\begin{tabular}{|c|c|}
\hline cDNA & Complementary deoxyribonucleic acid \\
\hline $\mathrm{CFU} / \mathrm{mL}$ & Colony forming units per milliliter \\
\hline CLSM & Confocal laser scanning microscope \\
\hline $\mathrm{Da}$ & Dalton \\
\hline DNA & Deoxyribonucleic acid \\
\hline eDNA & Extracellular DNA \\
\hline E. coli & Escherichia coli \\
\hline EPS & Extracellular polymeric substance \\
\hline GFP & Green fluorescent protein \\
\hline HGT & Horizontal gene transfer \\
\hline $\mathrm{h}$ & Hour \\
\hline IncP-9 & Incompatibility group P9 \\
\hline lac repressor & Lactose repressor \\
\hline LB & Lysogeny broth \\
\hline MIC & Minimum inhibitory concentration \\
\hline $\min$ & Minutes \\
\hline $\mathrm{MBC}$ & Minimum bactericidal concentration \\
\hline MBEC & Minimum biofilm eradication concentration \\
\hline OD & Optical density \\
\hline oriT & Origin of transfer \\
\hline PBS & Phosphate buffered saline \\
\hline P. putida & Pseudomonas putida \\
\hline RT-PCR & Reverse transcriptase polymerase chain reaction \\
\hline
\end{tabular}


RNA

S. typhimurium

spp.

T4SS

tra genes
Ribonucleic acid

Salmonella typhimurium

Species

Type IV secretion system

Transfer genes

xvii 


\section{List of Appendices}

\section{Appendix A}

Table A1. Minimum bactericidal concentration (MBC) of gentamicin for P. putida BBC443 with varying nutrient concentrations, $10^{5} \mathrm{CFU} / \mathrm{mL}$ was added as inoculum.

Table A2. Determination of minimum bactericidal concentrations (MBC) for P. putida BBC443 and $P$. putida ATCC12633 with $100 \%$ LB.

Table A3. Determination of minimum biofilm eradication concentration (MBEC) of P. putida ATCC12633 with $100 \%$ LB. 


\section{Chapter 1}

\section{Introduction}

\subsection{Motivation for the study}

Horizontal transfer of mobile genetic elements is an important mechanism of microbial adaptation to a changing environment (Top and Springael, 2003). Previous studies in our lab investigated the transfer of catabolic plasmid pJP4 in bacterial biofilms in lab-scale continuous flow-through chambers. The results revealed that transconjugants were not detected microscopically after the addition of a plasmid donor strain (Pseudomonas putida SM1443) to mature (7 days-old) soil derived biofilms which were more than $60 \mu \mathrm{m}$ thick (Shamsad, 2012). When the same donor strain was added to $24 \mathrm{~h}$ old $P$. putida ATCC12633 biofilms (15 $\mu \mathrm{m}$

thick), transconjugant cells were observed microscopically after $48 \mathrm{~h}$ of donor addition (Uddin, 2014). It is unclear whether more transconjugants were observed due to the potential increased penetration of donor cells into thinner biofilms, or if inhibition of donor penetration in older biofilms due to an increased production of extracellular polymeric substances (EPS) or cell growth stage-related parameters were involved. Limited information is available on how cell growth phases, of either donor or recipient cells, affect plasmid transfer in planktonic cell batch cultures and in biofilms (Muela et al., 1994).

Some studies revealed that antibiotics can act as signalling molecules. These studies showed that the presence of subinhibitory concentration of antibiotics altered the expression profiles for a variety of genes (Bagge et al., 2004, Hoffman et al., 2005). A study performed in our lab showed that a greater number of plasmid pJP4 transconjugant cells were detected when a soil-derived 
mixed culture biofilm was exposed to sublethal concentration of gentamicin $(100 \mu \mathrm{g} / \mathrm{mL})$ in comparison to an experimental control (no exposure to gentamicin) (Postelnik, 2012).

Based on literature search and studies that were performed in our lab, the following questions arose:

1. How do cell growth phases affect plasmid transfer and transconjugant formation?

2. Is expression of $\operatorname{traA}$ (encodes pilus biosynthesis) linked with a specific growth phase and does it correspond to enhanced transconjugant formation?

3. How does an environmental factor such as nutrient availability affect susceptibility of bacterial cells to antibiotics?

4. How does an environmental stressor such as an antibiotic influence plasmid transfer and transconjugant formation?

We formulated the following hypotheses based on the research questions.

1. In the exponential growth phase, cells grow and increase in number. In the stationary phase cell growth eventually ceases due to the nutrient limitation and accumulation of waste products. We hypothesized that the abundance of transconjugants will be higher in the exponential growth phase than in the stationary growth phase of the plasmid donor and recipient cells in plate matings, as cell activity is greater in the exponential phase. We also hypothesized that transconjugant formation will be enhanced when plasmid donor cells grown to exponential phase will be added in the recipient biofilms.

2. The traA gene encodes pilus biosynthesis in plasmid donor cells. We hypothesized that the traA gene expression in donor cells will be linked to a higher percentage of transconjugants. 
3. With decreased nutrient concentrations, bacterial cells will be less metabolically active and a lower minimum inhibitory concentration (MIC) of antibiotics will be needed to inhibit bacterial growth as fewer targets for the antibiotics will be available. We hypothesized that values of MIC of antibiotics will decrease with decreasing nutrient concentrations.

4. The number of transconjugants will be greater following antibiotic exposure due to a potential effect of antibiotics on gene expression.

To test the hypotheses we proposed the following objectives:

1a. To study the effect of cell growth phases (exponential and stationary) of plasmid donor and recipient cells on transconjugant formation using planktonic cell batch cultures.

1b. To study the effect of growth phases of plasmid donor cells on transconjugant formation in biofilms.

2. To develop and optimize an RT-PCR assay for the detection of traA expression.

3. To study the effect of varying nutrient concentrations on minimum inhibitory concentration of antibiotics.

4. To study the effect of exposure to subinhibitory and minimum inhibitory concentrations (MIC) of gentamicin on transconjugant formation using planktonically grown cells in plate matings and biofilms. 


\subsection{Horizontal gene transfer (HGT)}

Horizontal gene transfer (HGT) is the acquisition of foreign genes by microorganisms and this is not dependent on cell division. There are three mechanisms of HGT: transformation, transduction and conjugation. Figure 1.1 summarizes the three different mechanisms of HGT. Among these three, transformation was the first mechanism discovered in prokaryotes (Frost et al., 2005). Transformation includes uptake, integration and expression of extracellular DNA by bacterial cells. In transformation, bacterial cells develop the ability to take up DNA which is referred to as competence (Thomas and Neilsen, 2005). Transduction is mediated by bacteriophages. Bacteriophages infect bacterial cells, inject DNA into the host cell and the DNA becomes incorporated into the host cellular chromosome (Frost et al., 2005). In conjugation, conjugative plasmids and transposons are transferred from donor to recipient cell via cell-cell contact (Frost et al., 2005).

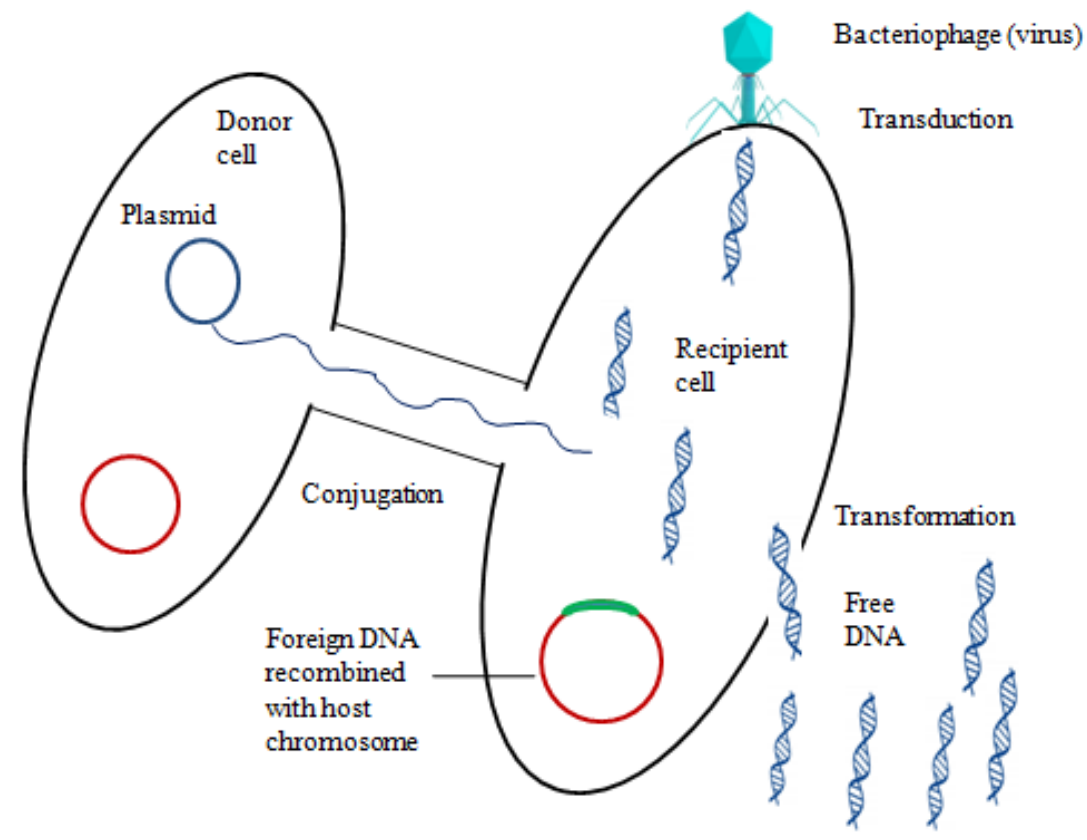

Figure 1.1. Mechanisms of horizontal gene transfer (HGT) (adapted from Stewart, 2013). 
For our research project conjugation was the mechanism of interest to study plasmid transfer manifested by transconjugant formation in plate matings and biofilms.

\subsubsection{Mechanism of conjugation}

Conjugation is found in Bacteria, Archaea, and Eukarya. In gram negative bacteria, conjugation can be divided into two stages. The first stage involves formation of a bridge between plasmid donor and recipient cells through extracellular conjugative pili. The second stage involves the transfer and processing of DNA (Yin and Stotzky, 1997). In gram negative bacteria, a conjugative pilus (mating pair formation apparatus) is formed in plasmid donor cell, which identifies plasmid recipient cell. Conjugative pilus retracts and brings the cells into close contact (Arutyunov and Frost, 2013). The type IV secretion system (T4SS) is needed for mating pair formation and gene transfer process. Type IV secretion systems are involved in protein secretions (Llosa et al., 2002). They contain channels through which protein- DNA complexes can be transferred between cells (Wallden et al., 2010). T4SS forms the transferosome which transports the DNA between cells. The relaxosome, a nucleoprotein complex at origin of transfer (oriT), contains the enzyme relaxase. In the F plasmid system, the relaxase is known as TraI. TraI makes a cut of DNA at the oriT by catalyzing the cleavage of specific phosphodiester and begins to separate a single DNA strand. The relaxosome is linked with the transferosome by the coupling protein (Frost and Koraimann, 2010). Coupling proteins are required in all conjugative systems. Some examples of coupling proteins are TrwB of IncW plasmid R388, TraD of IncF plasmids and TraG of IncP plasmids (Llosa et al., 2002). The DNA/relaxase complex is then recognized by the coupling protein and transferred to the secretion system (transferosome). The secretion system pumps the DNA/relaxase complex into the recipient cell. After entering the 
recipient cell, single stranded DNA is replicated to become double stranded (Wong et al., 2012, Willey et al., 2011).

F-like plasmids carry two genes that encode proteins that reduce mating between similar donor cells. These two proteins are an inner membrane entry exclusion (Eex) protein, TraS, and an outer membrane surface exclusion (Sfx) protein, TraT. (Achtman et al., 1977, Arutyunov and Frost, 2013). Transfer of the F plasmid takes $\sim 2$ min at a rate of $45 \mathrm{~kb} / \mathrm{min}$ (Arutyunov and Frost, 2013).

The majority of gram positive bacteria utilize T4SSs for conjugative passage of single stranded DNA (Goessweiner-Mohr et al., 2014). In gram positive enterococci, transfer apparatuses encoded by plasmids become activated in response to an appropriate recipient through production of pheromones. Recipient strains of gram positive Enterococcus faecalis produce and excrete diffusible, hydrophobic peptide molecules known as pheromones which act as chemical signals (Thomas and Neilsen, 2005, Writh, 1994). The donor strains of E. faecalis can sense the presence of the pheromones and produce aggregation substance which causes tight physical contact between donor and recipient cells until the transfer of the conjugative plasmids (Wirth, 1994). In gram positive bacteria, cell attachment occurs through the generation of surface factors or adhesins. PrgB is a protein encoded by plasmid pCF10, found in pheromone inducible conjugation in enterococci (Hirt et al., 2005). In gram positive Streptomycetes, the conjugative DNA transfer system depends on double stranded DNA translocation performed by a single protein TraB (Sepulveda et al., 2011). In Streptomyces, plasmid transfer occurs by the formation of "pock structures". Pocks are generated when donor spores germinate on a lawn of a plasmid free recipient. The pocks represent growth inhibition zones surrounding the plasmid donor where 
sporulation of recipient is retarded. Pocks indicate the area where the recipient mycelium has acquired a plasmid by conjugation (Thoma and Muth, 2016).

There are at least 3 families of conjugative plasmids (pSK41, pWBG749 and pWBG4) found in staphylococci. Of these only 5-6\% of plasmids carry conjugation gene clusters required for independent conjugative transfer. The conjugative plasmid encodes all genes required for formation of the mating pore, the coupling protein, DNA relaxase and oriT. DNA is brought to the mating pore by the relaxase protein, which cleaves and attaches to the oriT sequence, forms a nucleoprotein complex, relaxosome. The relaxasome is brought to the mating-pore through coupling protein and transferred to the recipient cell through type IV secretion system (Ramsay et al., 2016).

\subsection{Plasmids}

Plasmids are mostly circular, double stranded, self replicating DNA molecules. Plasmid genes do not encode essential cellular functions. Plasmids have a major role within the pool of horizontally exchangeable genes as plasmids encode genes for stress response, their autonomous replication, also encode genes for their own transfer (Smets et al., 1993). Plasmids cannot coexist in a cell together if they contain the same origin of replication. This is known as plasmid incompatibility (Velappan et al., 2007). Plasmids containing the same replication control are placed in the same incompatibility group. Plasmids are classified into different incompatibility groups e.g. IncC, IncN, IncP, IncQ, and IncW (Thomas and Smith, 1987).

Plasmids contain "backbone" genes that encode proteins involved in replication. Plasmids also contain accessory genes that encode different functions those are not encoded on the bacterial chromosome (Frost et al., 2005). The accessory region of plasmids contains the genes that 
encode biofilm formation factors e.g. fimbriae that mediate cell-cell contact needed for cluster formation, cell surface adherence and promote biofilm formation (Madsen et al., 2012). Many bacterial species carry plasmids.

\subsubsection{Pseudomonas spp.}

Species within the genus Pseudomonas are gram negative, flagellated, rod shaped, aerobic bacteria (Anzai et al., 2000), belonging to the Gamma-proteobacterial class and are common inhabitants of soil and water (https://www.ncbi.nlm.nih.gov/genome, retrieved on Sep 27, 2017). Pseudomonas spp. contains chromosomally encoded efflux mechanisms, which help to increase the antibiotic resistance in Pseudomonas spp. (Devarajan et al., 2017). Pseudomonas spp. contains $\mathrm{R}$ factor plasmids which encode genes for resistance to various antibiotics, such as gentamicin, tobramycin, carbenicillin. Sex-factor plasmids are found in both $P$. aeruginosa and P. putida. Heavy metal (e.g. mercury) resistance plasmids are also found in Pseudomonas spp. (Chakrabarty, 1976). P. aeruginosa has been used as a model organism for biofilm formation (Sauer et al. 2002). P. aeruginosa is an opportunistic pathogen and isolated from plant, animals and humans. It can be isolated from respiratory therapy equipment, medicines, physiotherapy and hydrotherapy pools (Lister et al. 2009). P. aeruginosa is the cause of nosocomial pneumonia, health care associated pneumonia, urinary tract infection, surgical site infection (Lister et al., 2009, Kollef et al., 2009).

In contrast to $P$. aeruginosa, $P$. putida is not frequently associated with clinical infection studies but $P$. putida has been used in different plasmid transfer studies. P. putida is found in soil and aquatic environments, and it has been occasionally found to colonize human tissue (Molina et al., 2014). In another study Molina et al. (2016), performed genomic comparisons between the 
environmental isolates and clinical isolates of $P$. putida. Genes detected in $P$. putida clinical isolates are related with survival under oxidative stress conditions, resistance against biocides, amino acid metabolism and toxin/antitoxin systems. These genes are absent in environmental $P$. putida isolates. These functions have influenced survival within human tissues since they help bacteria cells to avoid host immune response and developed enhanced stress resistance.

In this research project, we used $P$. putida strains to study pWWO transfer in biofilms and batch cultures. We investigated the effect of an environmental factor, i. e. nutrient availability, on susceptibility of bacterial cells to antibiotics and the effect of an environmental stressor, i. e. an antibiotic, on transconjugant formation in the biofilms. We used $P$. putida as it has been frequently used in different environmental studies, applications and also it is known for its capacity to form biofilms.

\subsubsection{TOL plasmid}

The TOL plasmid is a self-transmissible plasmid initially characterized in $P$. putida (arvilla) mt2 strain (Chakrabarty, 1976).

For our research project, a TOL plasmid pWWO was used to study plasmid transfer in biofilms and batch culture systems. TOL plasmid pWWO isolated from Pseudomonas putida belongs to incompability group IncP-9 (Ikuma and Gunsch, 2012). Plasmid pWWO encodes genes for catabolism of aromatic compounds xylene, toluene, m-ethyltoluene and 1, 3, 4-trimethylbenzene (Abril et al., 1989). Transfer of plasmid pWWO by conjugation has been documented in Pseudomonas spp. and Escherichia coli. Christensen et al. (1998) studied conjugative transfer of TOL plasmid pWWO in biofilms composed of three different species P. putida, Acinetobacter and an unknown strain. Among these three only P. putida received the plasmid. In another study, 
Jussila et al. (2006) showed that pWWO was transferred from Pseudomonas to Rhizobium. Boon et al. (2005) studied transfer of pWWO from P. putida to E. coli DH5a. Their study revealed high nutrient condition (contained maximum amount of carbon and nitrogen source) and optimal temperature were necessary to obtain higher plasmid transfer frequency.

\subsubsection{Plasmid replication process}

Circular plasmids are replicated by three mechanisms: theta type, strand displacement and rolling circle mechanism.

The theta type replication has been well studied for plasmids of gram negative bacteria and also for some plasmids of gram positive bacteria (Solar et al., 1998, Lilly and Camps, 2015). DNA replication by the theta type mechanism includes melting of the parental strands, synthesis of a primer RNA (pRNA), and initiation of DNA synthesis by extension of the pRNA.

The theta type replication can be unidirectional or bidirectional and DNA synthesis can start from single or different origins. DNA synthesis is continuous in one strand (leading strand, polymerase clamped to DNA continuously) and discontinuous in other strand (lagging strand, synthesized as fragments) (Solar et al., 1998, Kelman and O'Donnell, 1995).

The plasmid rolling circle mechanism depends on the cleavage at the nick site of the doublestrand origin of one of the parental DNA strands by an initiator Rep protein. This cleavage generates a 3-hydroxyl end that allows DNA polymerases to initiate the leading strand replication. Elongation of the leading strand takes place as the parental double helix is unwound by host DNA helicase. The $3^{\prime}$ end is lengthened and the growing point forms a circular template. The $5^{\prime}$ end of the strand is displaced to form an ever lengthening tail (Figure 1.2). A trans-esterification occurs that joins the $5^{\prime}$ end to the $3^{\prime}$ end, generated in the termination 
cleavage, and releases the displaced parental strand as a single-stranded DNA (ssDNA). This ssDNA serves as the template for the lagging strand. The ssDNA can be converted in double stranded DNA form by synthesis of a complementary strand (Ruiz-Maso et al., 2005, Willey et al., 2011).

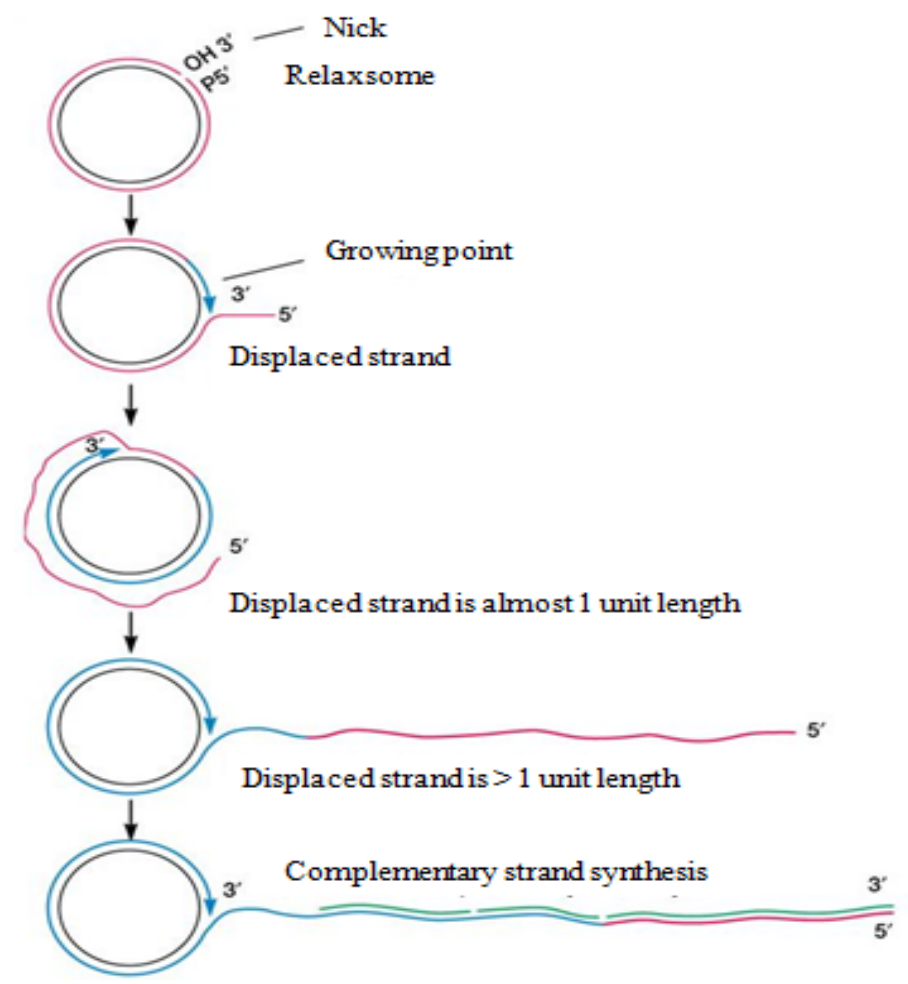

Figure 1.2. Rolling circle replication mechanism (adapted from Willey et al., 2011).

\subsubsection{Role of plasmid donor and recipient in conjugation}

In conjugation, the formation of contacts between two gram negative bacteria (plasmid donor and recipient) is mediated by conjugative pili. Conjugative pili are cylindrical filaments with an outside diameter of $8 \mathrm{~nm}$ and a $2 \mathrm{~nm}$ central, hydrophilic lumen, extending from the surface of 
donor cells (Silverman, 1997). According to Novotny and Fives-Taylor (1973), pili disappear as a result of retraction and some environmental factors, e.g. temperature, have an effect on pili retraction. Their study suggests that in Escherichia coli cells, retraction of pili occurs at a slower rate at $25^{\circ} \mathrm{C}$, but retraction is very slow or completely inhibited at temperatures below $24^{\circ} \mathrm{C}$. According to Seoane et al. (2011), recipient cells receive plasmids more frequently at the advanced stage of the growth cycle when cells are elongated. Further details are discussed in chapter 2 .

\subsubsection{Genes and proteins involved in conjugation}

The products of three $\mathrm{F}$ genes, $\operatorname{traA}$, traQ, and $\operatorname{traX}$ within the tra region are involved in synthesis of F-pilin subunits (Firth et al., 1996). In addition to the product of these three genes, TraB, TraC, TraE, TraF, TraG, TraH, TraK, TraL, TraU, TraV, TraW and TrbC are involed in pilus assembly (Frost et al., 1994). According to Anthony et al. (1999) TraL, TraE, TraK, TraC, TraG were involved in pilus tip formation. TraB, TraF, TraH, TraW, TraV were involved in pilus outgrowth and TrbI was involved in pilus retraction. F-like pilins have four domains, two hydrophobic domains inserted in the inner membrane, the $\mathrm{N}$ - and C-termini exposed in the periplasm, and a loop containing basic amino acids oriented towards the cytoplasm (Silverman 1997).

TraN, which is involved in mating pair stabilization, interacts with outer membrane protein and lipopolysacharide. TraG was the second stabilization protein and involved in entry exclusion. The functions encoded by the transfer region genes are summarized in Table 1.1. 
Table 1.1. Transfer region genes involved in plasmid transfer during conjugation (adapted from Firth et al., 1996)

\begin{tabular}{|c|c|c|c|}
\hline Gene & Functional group & Product location & References \\
\hline $\operatorname{traA}$ & $\begin{array}{l}\text { Pilus biogenesis (encodes } 121 \text { aa } \\
\text { precursor of the pilus subunit, propilin) }\end{array}$ & $\begin{array}{l}\text { Inner membrane } \\
\text { and } \\
\text { extracellularly }\end{array}$ & Frost et al., 1984 \\
\hline $\operatorname{traB}$ & Pilus biogenesis & Inner membrane & Moore et al., 1987 \\
\hline $\operatorname{traC}$ & Pilus biogenesis & $\begin{array}{l}\text { Cytoplasm/ Inner } \\
\text { membrane }\end{array}$ & Schandel et al., 1990 \\
\hline $\operatorname{traD}$ & $\begin{array}{l}\text { DNA metabolism (Purified TraD is an } \\
\text { integral inner membrane protein that it } \\
\text { is capable of binding to DNA. It has } \\
\text { been suggested that it forms or is part of } \\
\text { a non-specific pore for DNA export, or } \\
\text { that it directly energizes DNA transport. } \\
\text { TraD redirects energy utilization } \\
\text { towards DNA transport. It could be also } \\
\text { involved in signalling that the } \\
\text { relaxosome should move to a competent } \\
\text { conjugation pore.) }\end{array}$ & Inner membrane & $\begin{array}{l}\text { Panicker and Minkley 1992, } \\
\text { Jalajakumari and Manning } \\
\text { 1989, Arutyunov and Frost } \\
\text { 2013 }\end{array}$ \\
\hline traI & DNA metabolism & Cytoplasm & Abdel-Monem et al., 1983 \\
\hline traM & DNA metabolism & Cytoplasm & Di Laurenzio et al.,1992 \\
\hline $\operatorname{traN}$ & Aggregate stabilization & Outer membrane & Maneewannakul et al., 1993 \\
\hline $\operatorname{tra} Q$ & Pilus biogenesis (propilin maturation) & Inner membrane & Maneewannakul et al., 1993 \\
\hline $\operatorname{traX}$ & Pilus biogenesis (propilin maturation) & Inner membrane & Cram et al.,1991 \\
\hline $\operatorname{traY}$ & DNA metabolism & Cytoplasm & Fowler et al., 1983 \\
\hline
\end{tabular}

Figure 1.3. shows the genetic map of plasmid pWWO. Nineteen genes on the plasmid backbone are involved in transfer of pWWO. For plasmid pWWO, origin of transfer includes TraA, TraB, TraC and TraD and two hypothetical proteins (Orf176 and Orf177) (Greated et al., 2002). TraD is the DNA binding protein that facilitates relaxosome formation. Plasmid pWWO oriT sequences contain low $\mathrm{G}+\mathrm{C}$ content and nic sequence. mpfA-J genes encode the products involved in synthesis of conjugative pilus during mating pair formation.

Plasmid pWWO carries the $x y l$ genes for toluenes and xylenes degradation. This plasmid also carries mer operon which contains mercury resistance genes (Greated et al., 2002). 


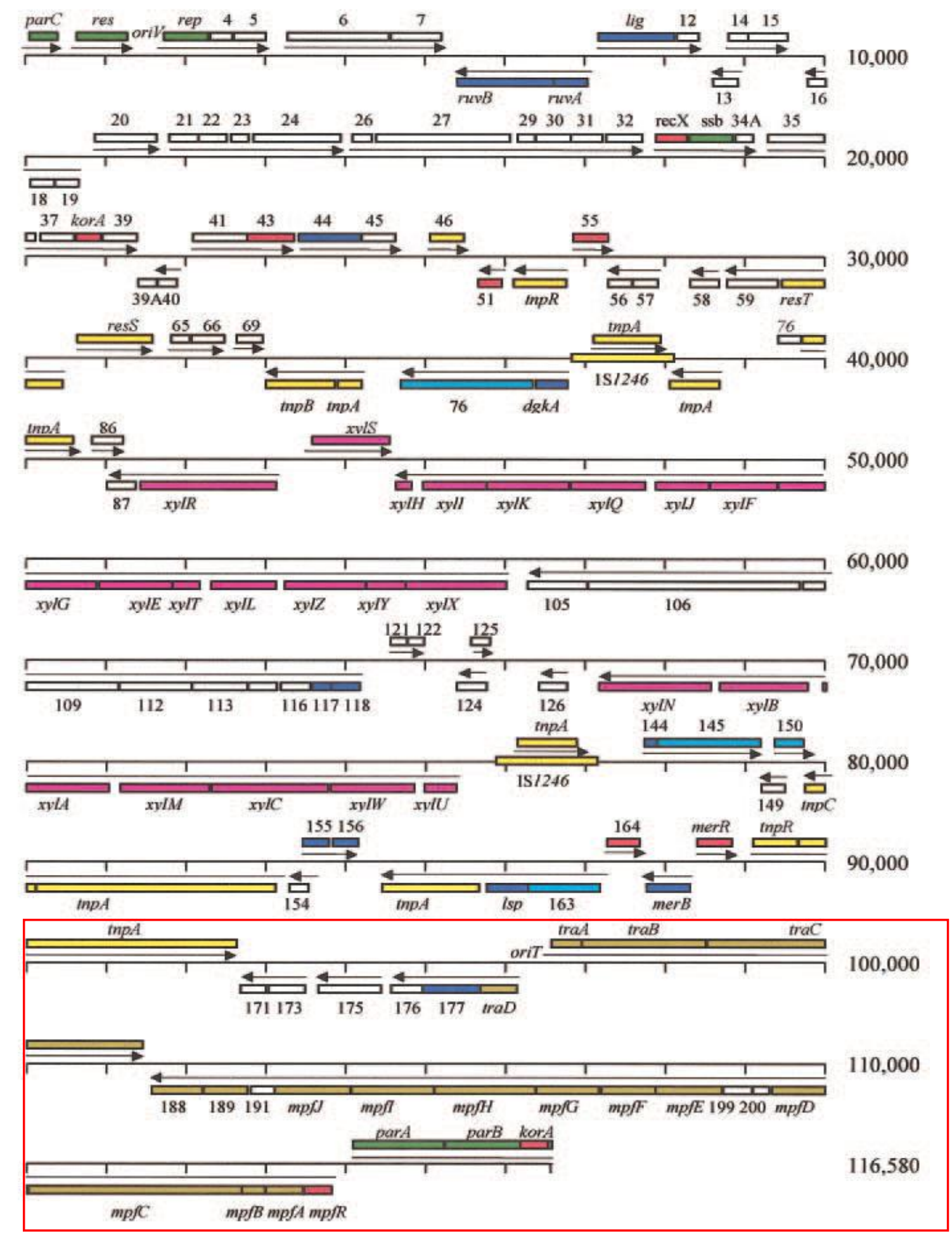

Figure 1.3. Genetic map of plasmid pWWO. Light green colour (in red box) represents proteins involved in conjugative transfer (From Greated et al., 2002). 


\subsubsection{Regulatory processes influencing conjugation and expression of genes in transconjugants}

Sorek et al. (2007) reported that the ability of bacteria to take up DNA by HGT depends on the Guanine-Cytosine (G-C) content of the genome. Their analysis suggests that G-C rich genomes contain fewer untransferable genes. Popa et al. (2011) found that with a high percentage of the horizontal gene transfer occurred between donor-recipient pairs having $\leq 5 \%$ difference in G-C content. Their results suggest that the barrier for gene acquisition from donors of dissimilar genomic G-C content creates a biological barrier and HGT occurs more frequently among closely related species, having similar genomes.

Ikuma and Gunsch (2012) investigated the effect of additional carbon sources, different $\mathrm{pH}$ values, different nutrient sources on toluene degradation ability of TOL pWWO plasmid containing transconjugants. Their results showed that glucose addition increased the toluene degradation ability in transconjugants. Different $\mathrm{pH}$ and nitrogen sources did not have a significant effect on the toluene degradation rate by the transconjugants.

A higher conjugation rate is linked to either the formation of bacterial aggregates under certain inoculum conditions or the recipient cell's genetic makeup (Pei and Gunsch, 2009). The highest amount of conjugation was seen for the treatment condition with the highest recipient cell ratio of 20:1 (activated sludge to $P$. putida BBC443). This result suggests that conjugation rate is associated with the availability of the recipient cells. Dahlberg et al. (1998) reported a similar trend in sea water where the highest plasmid transfer frequencies occurred with the lowest number of donor cells.

In conclusion, conjugation rate has been shown to depend on the G-C content of the genome, genome similarity and the ratio of donor to recipient cells. 


\subsection{Antibiotics}

Antibiotics are low molecular weight $(<3,000 \mathrm{Da})$ molecules produced by some fungi and bacteria (Laureti et al., 2013). Among bacteria, the genera Streptomyces, Bacillus, Pseudomonas are well known for their antibiotic-producing properties. Antibiotics might target cellular structures or enzymes. Common mode of action of antibiotics are the inhibition of the bacterial cell wall biosynthesis (e.g. $\beta$-lactam), the inhibition of protein (e.g. macrolides), RNA (e.g. ansamycins) or DNA synthesis (e.g. quinolones), the damage of cell membranes (e.g. polymyxins) and inhibition of essential metabolites (e.g. folate) synthesis (e.g. trimethoprim, class sulfonamides) (Laureti et al., 2013, Rasamiravaka and Jaziri, 2016). Antibiotics either kill bacteria directly (bactericidal mode) or inhibit bacterial growth (bacteriostatic mode) (Rasamiravaka and Jaziri, 2016).

The concentrations of these molecules required to achieve an antimicrobial effect is likely extremely high compared to the concentrations in which these molecules can be found in natural environments (Romero et al., 2011). The soluble concentrations of some antibiotics (e.g. tetracycline, ciprofloxacin, erythromycin) were found to be $\leq 1.3 \mu \mathrm{g} / \mathrm{L}$ in the wastewater facilities (Karthikeyan and Meyer, 2005). Antibiotics are used to treat human infections, they are also used in veterinary medicine and agriculture (Hirsch et al., 1999). Antibiotics are neither well metabolized by humans and animals nor are they fully biodegradable. These active forms of antibiotics pollute the soil and aquatic environments (Laureti et al., 2013). Subinhibitory concentrations (lower than the minimum inhibitory concentration) of antibiotics are found in the environment. 


\subsubsection{Subinhibitory concentrations of antibiotics act as signalling molecules, mechanisms of signalling molecules}

Some studies have revealed that exposure to subinhibitory concentrations of antibiotics induces changes in the expression profile of a wide range of genes in different bacterial species (Davies et al., 2006, Bagge et al., 2004, Hoffman et al., 2005).

Bagge et al. (2004) studied the influence of subinhibitory concentration of imipenem ( $\beta$-lactam antibiotic) on the structure of $P$. aeruginosa PAO1 biofilm. The authors compared nontreated (not exposed to imipenem) biofilms to biofilms exposed to imipenem for 18 or $37 \mathrm{~h}$. Biofilms exposed to imipenem developed more biomass per substratum area and an increased average thickness. Control (not exposed to imipenem) biofilms formed numerous towers and pillars of microcolonies separated by areas devoid of cells. Their study demonstrated that among the genes that responded to imipenem exposure were the alginate biosynthesis genes $(\operatorname{alg} D$ to $\operatorname{alg} A)$. The exposure to subinhibitory concentrations of imipenem (a $\beta$-lactam antibiotic) caused an increased biofilm volume due to the production of alginate (exopolysaccharide) in the $P$. aeruginosa strain PAO1 biofilm. The authors concluded that increased production of alginate decreases the susceptibilities of bacteria growing in biofilms to antibiotics. The penetration of antibiotics through the biofilm may be reduced due to binding to alginate.

According to Goh et al. (2002) in the presence of low concentrations of erythromycin and rifampicin, global bacterial transcription patterns were altered by the stimulation or inhibition of a variety of promoter-lux reporter constructs in a library of Salmonella typhimurium. At subinhibitory concentrations these two antibiotics stimulated or inhibited many different promoters in S. typhimurium. Genes encoded different functions e.g. transport, virulence and DNA repair were activated by subinhibitory concentrations of antibiotics. The authors concluded 
that in the presence of subinhibitory concentrations of antibiotics "the transcription machinery must have the means to sense these subtle conformational or stoichiometric changes and respond by specific up or down regulation." They also concluded that transcriptional modulation by antibiotics could lead to negative effects during the treatment of bacterial infections in human hosts.

\subsubsection{Minimum inhibitory concentration (MIC), Minimum bactericidal concentration (MBC), Minimum biofilm eradication concentration (MBEC)}

Antimicrobial susceptibility testing is important to detect susceptibility or resistance in bacteria to different antimicrobials (Jorgensen and Ferraro, 2009). Minimum inhibitory concentrations (MIC) are the lowest concentrations of antimicrobials that inhibit visible growth of bacteria after overnight incubation. MIC is the standard technique for determination of susceptibility of microorganisms to antimicrobials. Minimum bactericidal concentrations (MBC) are the lowest concentrations of an antimicrobial agent that prevent the growth of bacteria after sub culturing onto antibiotic free media. The minimal biofilm eradication concentration (MBEC) is the minimal concentration of antimicrobial agents that can kill bacteria existing in a biofilm (Takei et al., 2013).

Biofilm cells are more resistant to antibiotics than the planktonic cells. Some factors provide antibiotic tolerance for biofilms e.g. (1) slow growth (2) presence of exopolysaccharides that prevent antibiotic diffusion and bind with the antibiotics (3) presence of persister cells (4) expression of resistance genes (Spoering and Lewis, 2001, Lewis, 2001). According to Giwercman et al. (1991) in the presence of $\beta$-lactam antibiotics, imipenem and piperacillin, $\beta$ lactamase production in $P$. aeruginosa biofilms was induced. The authors concluded that the 
production of $\beta$-lactamase was the reason for persistence of $P$. aeruginosa in chronic infections. The $\beta$-lactamase enzymes provide resistance to $\beta$-lactam antibiotics by disrupting the beta lactam ring (http://medical-dictionary.thefreedictionary.com/Beta+lactamase, retrieved Jan 08, 2017).

For our research project MIC, MBC, and MBEC were measured for gentamicin (an aminoglycoside), kanamycin (an aminoglycoside), tetracycline (tetracyclines) and rifampicin (rifamycin) for $P$. putida strains at different nutrient concentrations.

\subsubsection{Aminoglycoside antibiotics: usage, toxicity}

Aminoglycosides produced by Streptomyces and Micromonospora species (Farouk et al., 2015), are broad spectrum antibiotics that are used to treat infections caused by gram positive and gram negative bacteria, such as Staphylococci, Enterobacteriaceae, Pseudomonas, and Acinetobacter spp (Hanberger et al., 2013). Examples of aminoglycoside antibiotics are kanamycin, gentamicin, neomycin, tobramycin (Farouk et al., 2015). Aminoglycoside antibiotics are administered as ointments, ear drops, nasal drops or by injections. These antibiotics are also used to promote growth and prevent infections in animals (Farouk et al., 2015). Aminoglycosides kill bacteria by binding to the bacterial ribosome and inhibiting protein synthesis. These antibiotics bind to the highly conserved A-site (transfer RNA acceptor site) of bacterial 16S ribosomal RNA of the 30S ribosomal subunit (Magnet and Blanchard, 2005). The toxicity of aminoglycoside antibiotics includes ototoxicity (e.g. streptomycin, gentamicin) and nephrotoxicity (e.g. neomycin). Aminoglycosides generate free radicals within the inner ear which may cause permanent damage to sensory cells and neurons, resulting in permanent hearing loss (Hanberger et al., 2013, Selimoglu, 2007). In this research project the effect of subinhibitory concentration 
and minimum inhibitory concentration of an aminoglycoside antibiotic, gentamicin was studied on transconjugant formation in batch cultures and biofilms.

\subsection{Scope of work and thesis outline}

Existing literature only sparsely addresses questions such as how cell growth phases affect plasmid transfer and transconjugant formation in batch cultures and biofilms, and how subinhibitory and minimum inhibitory concentrations of a selected antibiotic (gentamicin) affect plasmid transfer and transconjugant formation in batch cultures and biofilms. The research carried out within the frame of this thesis consisted of four projects to satisfy the four objectives listed in section 1.1.

The projects are listed below:

1. Effect of cell growth phases on transconjugant formation in plate matings and biofilms.

2. Optimization of RT-PCR to detect expression of the traA gene in plasmid donor cells.

3. Effect of nutrient concentrations on the determination of minimum inhibitory concentration of antibiotics.

4. Effect of subinhibitory and minimum inhibitory concentration of gentamicin on transconjugant formation in plate matings and biofilms.

The background information of the projects is described in chapter 2 . The materials and methods of the experiments are described in chapter 3. The results obtained from the experiments are described in chapter 4. The discussion of experimental data is found in chapter 5.

Chapter 6 outlines the conclusions and suggests recommendations as a follow up for this project. The appendices contain the supporting data for "Effect of nutrient concentrations on the 
determination of minimum inhibitory concentration of antibiotics". References are listed at the end of the thesis. 


\section{Chapter 2}

\section{Background}

\subsection{Project 1: Effect of cell growth phases on transconjugant formation in plate matings and in biofilms}

Horizontal transfer of mobile genetic elements is an important mechanism of microbial adaptation to a changing environment and bacterial cells evolve rapidly by transfer of DNA (Top and Springael, 2003, Thomas and Neilsen, 2005). Conjugation of plasmids, the spread of extrachromosomal DNA between cells mediated by cell to cell contact, is an important mechanism of HGT. Plasmid transfer has been studied in both batch cultures and in biofilms (e.g. Bathe et al., 2004, 2005, 2009).

In the natural environment, microorganisms predominantly exist enclosed in a self-secreted matrix of extracellular polymeric substances (EPS) in the form of biofilms or other bioaggregates, rather than as individual cells, and usually exist in the stationary growth phase (Gefen et al., 2014). The steps involved in biofilm formation are (i) reversible attachment: initial attachment of the bacteria cells to the substratum, (ii) irreversible attachment: cells are cemented to the substratum and form cell clusters, (iii) cell clusters are matured and cells are embedded in the EPS, (iv) dispersion: cells are detached from the cell cluster (Sauer et al., 2002). Bester et al. (2005) showed that bacterial cells are not detached only from the established biofilms but also from the younger biofilms. The bacterial cells in the deeper layer of the biofilms have decreased growth rate due to spatial and substrate limitation.

Biofilms provide favourable conditions for HGT due to the close contact between microbial cells (Madsen et al., 2012). A study done by Cook et al. (2011) showed that the copy number of plasmid pCF10 was increased 1.5 - 2 times in gram positive Enterococcus faecalis biofilms than 
that of the planktonic cells. The increased number of pCF10 altered the responses to $\mathrm{cCF} 10$ which is a sex pheromone excreted by the recipient cell. Donor cells with more copy numbers of pCF10 responded to cCF10 more efficiently than the cells with low copy number of plasmid.

Further, plasmid carriage promotes biofilm formation through the expression of conjugative $\mathrm{F}$ pili which stimulate cell to cell contact between plasmid donor and recipient cells (Ghigo, 2001, Reisner et al., 2006, D’Alvise et al., 2010).

During conjugation, the filamentous tube like F-pilus (or conjugative pilus) is needed to form a mating pair between the plasmid donor and recipient cell to facilitate the transfer of DNA from donor to recipient cell. The DNA is transferred from the donor to the recipient cell as single stranded and becomes double stranded in the recipient cell by the formation of a complementary strand. F-pilus which is 1-2 $\mu \mathrm{m}$ in length, $8.5-9 \mathrm{~nm}$ in diameter attached to the surface of plasmid donor cells (Firth et al., 1996). traA, is the first gene in the tra operon. (Babic et al., 2008, Kalkum et al., 2002, Greated et al., 2002). traA encodes 121 amino acid precursors of the pilus subunit (Frost et al.,1984).

Bacterial cells in the deeper layers of established biofilms exhibit lower growth activity due to oxygen and nutrient limitation, similar to a stationary phase in a batch culture system where population growth eventually ceases due to nutrient limitation and waste product accumulation. Thus, the steady state of biofilm development may resemble stationary growth phase cultures (Collet et al., 2008). Cell size changes during the different phases of growth have been documented, showing that cell size decreases as cells near the end of the exponential growth phase and enter the stationary phase (Akerlund et al., 1995). Variations in cell size may influence conjugation rates. Seoane et al. (2011) have shown that cell elongation likely facilitates conjugation. In addition to cell size, plasmid conjugation rates can be affected by many biotic 
and abiotic factors such as bacterial cell density (Normander et al., 1998), nutrient availability (Smets et al., 1993, Fox et al., 2008), or spatial architecture of the bacterial community (Molin and Tolker-Nielsen, 2003, Licht et al., 1999). In the exponential growth phase, microorganisms grow and divide at the maximum rate. Contrary, in the stationary growth phase, population growth slows down due to nutrient and oxygen limitation (Willey et al., 2011). In the long term stationary phase, expression of stress response genes (e.g. $r p o S)$ is needed for the survival of bacterial cells (Finkel, 2006).

Limited information is available on how cell growth phases (and associated changes in cell size) affect plasmid transfer in planktonic cell batch cultures and in biofilms. Our objectives for this project were to investigate the effect of cell growth phases (exponential and stationary) of plasmid donor and recipient cells on transconjugant formation using planktonic cells in plate mating experiments and to study the effect of different growth phases of the plasmid donor on transconjugant formation in biofilms. To determine if conjugative pilus biosynthesis is linked to a specific growth phase of donor cells and enhanced transconjugant formation, we developed an RT-PCR assay to determine the expression of $\operatorname{traA}$ gene. For our study, we used the TOL plasmid pWWO which is a $117 \mathrm{~kb}$ plasmid and belongs to the IncP-9 group (Greated et al., 2002). Previously, pWWO was used to study plasmid transfer in batch cultures and biofilms (Pei and Gunch, 2009, Seoane et al., 2011, Boon et al., 2002, Christensen et al., 1993). In the exponential growth phase, cells grow and increase in number.

In the exponential growth phase, cells grow and increase in number. In the stationary phase cell growth eventually ceases due to the nutrient limitation and accumulation of waste products. We hypothesized that the abundance of transconjugants will be higher in the exponential growth phase than in the stationary growth phase of the plasmid donor and recipient cells in plate 
matings, as cell activity is greater in the exponential phase. We also hypothesized that transconjugant formation will be enhanced when plasmid donor cells grown to exponential phase will be added in the recipient biofilms. The traA gene encodes pilus biosynthesis in plasmid donor cells. We hypothesized that the traA gene expression in donor cells will be linked to a higher percentage of transconjugants.

\subsection{Project 2: Optimization of RT-PCR to detect expression of $\operatorname{traA}$ in plasmid donor cells}

The polymerase chain reaction (PCR) is an accurate and rapid method for the detection of target DNA. As DNA is stable outside of cells, PCR provides positive results for both live and dead bacterial cells (Molaee et al., 2015). Quantitative PCR (qPCR) is the quantitative measurement of amplified DNA. Reverse transcriptase polymerase chain reaction (RT-PCR) is a suitable method for detecting the presence of living cells as well as gene expression, as this method targets RNA and in contrast to DNA, RNA is not stable once released from cells. RT-PCR is used to detect and quantify gene expression through the creation and amplification of complementary DNA (cDNA) reverse-transcribed from mRNA. Reverse transcription quantitative PCR (RT-qPCR) has been established as a method of choice for the quantification of mRNA transcripts of a gene of interest in biological samples (Volland et al., 2017). To determine relative changes in gene expression, a relative quantification can be used based on the relative expression of a target gene versus a reference gene (Pfaffl, 2001). An absolute quantification can be done using a calibration curve.

Bustin et al. (2009) summarized the essential information that should be included in publications in "The MIQE guidelines: Minimum Information for Publication of Quantitative Real-Time PCR 
Experiments". According to their guidelines, the authors recommended to include information about experimental set up, sample preparation and storage, nucleic acid extraction, reverse transcription, qPCR target information, $\mathrm{qPCR}$ protocol, $\mathrm{qPCR}$ oligonucleotides, $\mathrm{qPCR}$ validation, data analysis in the manuscripts. In this research project RT-PCR was used to detect the expression of the traA gene which encodes pilus synthesis in Pseudomonas putida BBC443 plasmid donor cells. This section outlines steps undertaken to optimize the RT-PCR technique (Figure 2.1) for the detection of traA gene expression. It highlights the importance of the use of appropriate controls to eliminate false-positive results.

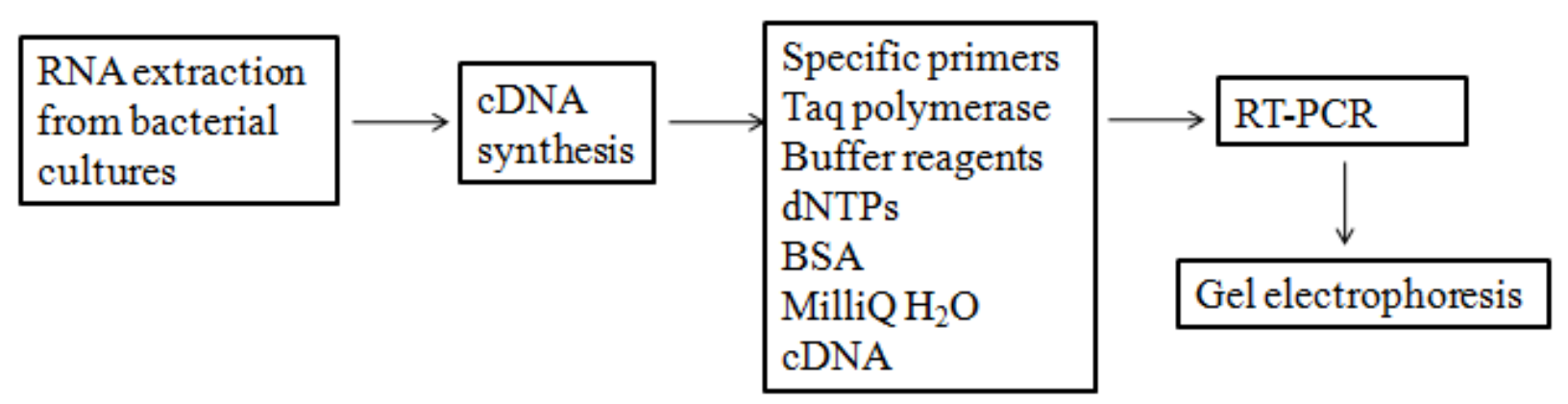

Figure 2.1. Steps involved in detection of gene expression using RT-PCR

\subsection{Project 3: Effect of nutrient concentrations on the determination of minimum inhibitory concentration of antibiotics}

In the environment, antibiotics are present at subinhibitory concentrations due to their extensive use in the treatment of human infections, veterinary medicine and agriculture (Laureti et al., 2013, Romero et al., 2011). 
Spread of antibiotic resistance has become a problem for medical practice as resistant bacteria are causing increased number of infections which cannot be treated with existing antibiotics (Laureti et al., 2013, Bruchmann et al., 2013). Nutrient availability influences the physiological status of bacterial cells and this, in turn, may affect bacterial response to antibiotics (Smith and Prairie, 2004). In this study, we investigated the effect of nutrient concentration on MIC of antibiotic determination. MIC is the lowest concentrations of an antimicrobial that inhibits visible growth of bacteria after overnight incubation (Andrews, 2001). Nutrient concentration varies in both environmental and clinical conditions and microorganisms may experience nutrient limiting conditions in such environments. In our study, we used the strains Pseudomonas putida BBC443 and $P$. putida ATCC12633. These two strains were used in our previous studies (Shamsad and Hausner, submitted) and also in project 4 (refer to page 29). P. putida BBC443 carries plasmid pWWO which contains a kanamycin resistance gene (Pei and Gunsh, 2009, Christensen et al., 1993). Kanamycin is an aminoglycoside antibiotic (Mingeot-Leclercq et al., 1999). For our study, we investigated the effect of another aminoglycoside antibiotic gentamicin for which resistance was not encoded on the plasmid or the chromosome of either one of the two Pseudomonas strains. Neither strain is known to possess resistance against gentamicin.

A large group of aminoglycoside antibiotics are bactericidal although they have different ribosomal binding sites (Mingeot-Leclercq et al., 1999). Aminoglycoside antibiotics are bactericidal (Willey et al., 2011). Gentamicin binds with the 30S ribosomal subunit and inhibits protein synthesis (Kadurugamuwa et al., 1993). Gentamicin is an aminoglycoside antibiotic and inhibitor of protein synthesis by disturbing the elongation of peptide chain (Hahn and Sarre, 1969, Kadurugamuwa et al., 1993, Molina et al., 2014). Aminoglycoside modifying enzymes e.g. aminoglycoside 6'-N acetyltransferase, aminoglycoside 2"-adenylyltransferase, and 
aminoglycoside acetyltransferases provide resistance to gentamicin (Zembower et al., 1998). A functional group of these enzymes binds with the antibiotic and inhibits the activity of the antibiotic (Azucena and Mobashery, 2001). Transport of aminoglycosides depends on electron transport and can be inhibited by low $\mathrm{pH}$, hyperosmolarity and anaerobic conditions (MingeotLeclercq et al., 1999). A decreased uptake of the antibiotics due to membrane impermeability can also cause resistance for all aminoglycosides (Mingeot-Leclercq et al., 1999).

When cells lyse, DNA is released, and cells may also actively secrete DNA. Binding of DNA with aminoglycosides can contribute to inhibition of uptake and increases resistance (Chiang et al., 2013). Negatively charged cell components may also bind aminoglycosides and affect MIC. Bacterial metabolism may lead to changes in $\mathrm{pH}$ and influence aminoglycoside uptake. Limited information is available on the effect of nutrient concentration, inactivated biomass, extracellular DNA and $\mathrm{pH}$ on MIC of antibiotics. The objective of this project was to determine the MIC of selected antibiotics under varying nutrient concentrations and to investigate potential effects of biomass and extracellular DNA availability on the MIC of gentamicin. We tested the effect of cell numbers (as inoculum), extracellular DNA and biomass on MIC of gentamicin to determine if theses provide protective effect from gentamicin. We measured $\mathrm{pH}$ when different cell numbers were added as inoculum to detect if $\mathrm{pH}$ changes after incubation.

With decreased nutrient concentrations, bacterial cells will be less metabolically active and a lower MIC of antibiotics will be needed to inhibit bacterial growth as fewer targets for the antibiotics will be available. We hypothesized that values of MIC of antibiotics will decrease with decreasing nutrient concentrations.

We chose gentamicin as a representative of the aminoglycoside antibiotics and also because gentamicin was used in project 4 where we investigated the effect of MIC and subinhibitory 
concentration of gentamicin on plasmid transfer in batch cultures and biofilms (Shamsad and Hausner, in preparation).

\subsection{Project 4: The effects of subinhibitory and minimum inhibitory concentrations of gentamicin on transconjugant formation in plate matings and biofilms}

Antibiotics are chemotherapeutic agents, which are a powerful tool to treat bacterial diseases (Sengupta et al., 2013). These molecules are produced by fungi and bacteria. Antibiotics are used in medicine and agriculture. Antibiotics are not fully metabolized by humans and are not biodegradable. Depending on the class of antibiotics, a large amount (20-80\%) of the administered antibiotics are excreted by humans and animals as unchanged chemicals and released in the environment (Anderson and Hughes, 2014). As a result, an active form of antibiotics remains in the environment at subinhibitory concentrations (Laureti et al., 2013). Antibiotics also have been shown to act as signalling molecules that induce changes in gene expression in microbial populations and influence physiological functions such as motility and

production of metabolites (Romero et al., 2011, Laureti et al., 2013, Baharoglu and Mazel, 2011).

Some studies have demonstrated that subinhibitory concentrations of antibiotics can upregulate expression of genes (e.g. in Pseudomonas aeruginosa, an aminoglycoside response regulator, arr gene) and enhance biofilm formation (Hoffman et al., 2005, Bagge et al., 2004). Ma and Bryers (2012) demonstrated that plasmid transfer was enhanced in biofilms exposed to subinhibitory concentration of antibiotics for which resistance was encoded on the plasmid.

Biofilms present considerable challenges to the successful eradication of bacterial infection since they act to protect bacteria from the effects of both the host immune system and antibacterial 
drugs (Davies, 2003). Biofilm bacteria are less responsive to antibiotic stressors than planktonic organisms of the same species as extracellular polymeric substances (EPS) of biofilms provide protection (Stewart, 2002). EPS contain exopolysaccharides, proteins and extracellular DNA. Binding of antibiotics with these components reduces the penetration of antibiotics through the biofilms (Ciofu and Tolker-Nielsen, 2011, Hoiby et al., 2010). Other reasons of antibiotic resistance of biofilms include slow growth of biofilm cells, presence of persister cells (spore like state) and adaptive stress response of biofilm cells (Stewart, 2002). Walters III et al. (2003) analysed the roles of antimicrobial penetration, oxygen limitation, and low metabolic activity in the tolerance of $P$. aeruginosa biofilms to ciprofloxacin and tobramycin. Biofilms were treated with ciprofloxacin $(1.0 \mu \mathrm{g} / \mathrm{mL})$ for $12 \mathrm{~h}$ and tobramycin $(10 \mu \mathrm{g} / \mathrm{mL})$ for $36 \mathrm{~h}$. The minimum inhibitory concentrations (MICs) for ciprofloxacin and tobramycin were $0.1 \mu \mathrm{g} / \mathrm{mL}$ and 0.01 $\mu \mathrm{g} / \mathrm{mL}$ respectively. The authors found that both antibiotics were able to kill only metabolically active bacteria located in zones with high oxygen concentration, suggesting that low metabolic activity is more relevant to biofilm antibiotic tolerance.

Subinhibitory concentrations of aminoglycoside antibiotics (which are widely used to treat chronic bacterial infections of heart, lung and urinary tract e.g. kanamycin, gentamicin) induced biofilm formation in P. aeruginosa and E. coli (Hoffman et al., 2005). Ma and Bryers (2012) investigated the effect of subinhibitory concentration of kanamycin and imipenem on the transfer of the TOL plasmid pWWO in Pseudomonas putida donor and Pseudomonas putida recipient cultures. Their results demonstrated enhanced transfer of pWWO (which carried a kanamycin resistance gene) in biofilms exposed to subinhibitory concentration of kanamycin $(2.5 \mu \mathrm{g} / \mathrm{mL})$, up to tenfold. Also, the biofilms exposed to subinhibitory concentrations of kanamycin had higher thickness and cell density than biofilms which were not exposed to antibiotics. However, 
after imipenem (for which resistance was not encoded on the plasmid) exposure, biofilm cell population and overall biofilm amount were also enhanced compared to the controls (no antibiotic), but transconjugant populations were not increased. The authors concluded that "biofilm bacteria might sense antibiotics to which they are resistant and subsequently enhance the spread of that resistance". According to Salcedo et al. (2015), the highest biomass and number of transconjugants were obtained for E. coli (plasmid donor) and P. aeruginosa (plasmid recipient) mixed culture biofilms at the 100-1000 ppb levels (approximately corresponding to values near or below MIC for e.g. gentamicin) of antibiotics. In summary, subinhibitory concentrations of antibiotics may enhance both horizontal gene transfer and biofilm development.

In this study, we investigated the effect of subinhibitory concentration and minimum inhibitory concentration of gentamicin on transconjugant formation in planktonic cell batch cultures. We also investigated the effect of subinhibitory concentration of gentamicin in biofilms, grown in 24 well plates. Gentamicin is an aminoglycoside antibiotic and effective in the treatment of gramnegative infections (Hathorn et al., 2014). We hypothesized that the number of transconjugant will be greater with the exposure to gentamicin from that of the control (without gentamicin) due to the action of antibiotics as signalling molecules which may change gene expression due to the alteration of transcription patterns. For this study, we used plasmid pWWO donor strain Pseudomonas putida BBC443. A gene for kanamycin resistance is encoded on the plasmid. Like kanamycin, gentamicin is also an aminoglycoside antibiotic, but the test strain does not carry genetically-encoded resistance against gentamicin. The objective of this study was to test the effect of gentamicin on transconjugant formation in plate matings and biofilms. 


\section{Chapter 3}

\section{Materials and methods}

\subsection{Effect of cell growth phases on transconjugant formation using planktonic cultures and in biofilms}

\subsubsection{Strains and media}

Modified Pseudomonas putida BBC443 strain (Christensen et al., 1998, Pei and Gunsch, 2009) carrying a green fluorescent protein tagged derivative of TOL plasmid pWWO, which also carries a kanamycin resistance gene was used as a plasmid donor strain (kindly provided by Dr. C. Gunsch, Duke University, with permission of Dr. S. Molin, Technical University of Denmark). Pseudomonas putida ATCC12633 was used as a plasmid recipient strain. P. putida BBC443 was derived by inserting a mini-Tn5-LacIq-cassette into the $P$. putida KT2442 chromosome and by modifying the TOL plasmid inserting a mini-Tn5-PA $1-/ 04 / 03:$ :gfpmut3b cassette (Christensen et al., 1998).

P. putida $\mathrm{BBC} 443$ has chromosomally encoded rifampicin resistance and contains the lacI $^{q}$ repressor gene on its chromosome. The product of this gene represses the expression of the green fluorescent protein which is under the control of an Escherichia coli lac-derived promoter. The recipient strain $P$. putida ATCC12633 did not carry lacl $^{q}$ repressor gene, therefore, green fluorescence was expressed in transconjugant cells after the transfer of plasmid from donor to recipient cell. Lysogeny broth (LB) (Bioshop Inc., ON, Canada) was used to grow the plasmid donor and recipient strains. For donor strain cultivation, kanamycin (Bioshop Inc., ON, Canada) was added for a final concentration of $50 \mu \mathrm{g} / \mathrm{mL}$. Cultures were incubated at room temperature on a table shaker (390 rpm). 


\subsubsection{Growth curve}

To study the effect of growth phases on plasmid transfer in planktonic cell batch cultures, growth curves of $P$. putida BBC443 and P. putida ATCC12633 were generated. Separate flasks with LB broth medium were inoculated with overnight cultures of each strain and incubated at room temperature with shaking at $390 \mathrm{rpm}$. Optical density readings were measured by spectrophotometer (Biophotometer, Eppendorf) and plate counts on LB plates were done to calculate $\mathrm{CFU} / \mathrm{mL}$ and generate the growth curves for each strain.

\subsubsection{Plate mating experiments}

Recipient and donor strains were grown for 6.5 to $7.0 \mathrm{~h}$ to reach early exponential growth phase or to $144 \mathrm{~h}$ to reach late stationary growth phase prior to the setup of mating experiments. A concentration of $10^{8} \mathrm{CFU} / \mathrm{mL}$ of donor and recipient strains was used for all mating experiments. Cells were washed twice with $0.9 \%$ saline. Cell pellets were resuspended with $1 \mathrm{~mL} 0.9 \%$ saline. Donor and recipient cell solutions $(200 \mu \mathrm{L}$ of each) were transferred into a $1.5 \mathrm{~mL}$ vial and mixed well by vortexing. Cell suspensions $(20 \mu \mathrm{L})$ of the mixture of the donor and recipient cells were spot-plated onto 3 different LB plates. Plates were incubated at room temperature for $72 \mathrm{~h}$. On day 3 the entire mating patch was harvested and resuspended in $0.9 \%$ saline solution, mixed well and centrifuged at $7000 \times \mathrm{g}$ for 8 minutes, stained and analyzed as described below.

\subsubsection{Detection and quantification of cells and EPS}

To estimate transconjugants expressed as a percentage of all cells and the amount of EPS produced in plate mating experiments, cell pellets from mating patches were stained with the nucleic acid binding stain Syto 62 (1:1000 dilution) (Invitrogen, MA, USA) and a fluorescently 
labelled lectin (Con A - TRITC; Invitrogen, MA, USA) $(0.1 \mathrm{mg} / \mathrm{mL})$ (Johnsen et al., 2000) to visualize all cells and polysaccharides within EPS, respectively. Staining solutions (250 $\mu \mathrm{L})$ were added to cell pellets in $1.5 \mathrm{~mL}$ vials and the vials were incubated for 20 minutes in the dark. Next, each pellet was washed with $1 \mathrm{~mL}$ of $0.9 \%$ saline. Five $\mu \mathrm{L}$ of the mating patch solutions were examined microscopically. Transconjugants were detected on the basis of their GFP mediated fluorescence. Twenty to twenty five images were collected using a confocal laser scanning microscope (CLSM) (LSM510, Carl Zeiss, Jena, Germany) using the $488 \mathrm{~nm}$ and 633 $\mathrm{nm}$ laser lines to detect transconjugants and to estimate total cells, respectively. The $543 \mathrm{~nm}$ laser line was used to visualize ConA binding to EPS. Images obtained with the CLSM were analyzed using NIH ImageJ (http.//rsb.info.nih.gov/ij/). Images were manually thresholded and the proportion of transconjugants as a percentage of all cells was determined using the "area fraction" command within the "analyze" menu of ImageJ.

\subsubsection{Transconjugant formation in biofilms}

To grow the recipient biofilm, sterile microscopic slides were submerged in a sterile $50 \mathrm{~mL}$ tube with $24.5 \mathrm{~mL}$ of LB medium and $0.5 \mathrm{~mL}$ of overnight culture of recipient $P$. putida ATCC12633, and incubated for $24 \mathrm{~h}$ at room temperature on a shaker at $100 \mathrm{rpm}$, similar to a procedure described by Krol et al. (2011). Microscopic slides with $24 \mathrm{~h}$ old biofilms were washed by dipping in $50 \mathrm{~mL} 0.9 \%$ saline to remove non-attached cells and then the slides were transferred to $25 \mathrm{~mL}$ of donor cultures grown to early exponential phase or late stationary phase and incubated for $12-14 \mathrm{~h}$ at room temperature on a shaker at $100 \mathrm{rpm}$. After $12-14 \mathrm{~h}$ unattached cells were removed by dipping the slides in $50 \mathrm{~mL} 0.9 \%$ saline and then transferred to fresh $\mathrm{LB}$ medium. The slides were transferred daily to tubes with $25 \mathrm{~mL}$ fresh LB medium. After $72 \mathrm{~h}$, the 
biofilms on slides were washed with $0.9 \%$ saline and stained with Syto 62 for 20 min in the dark. After staining the slides were washed by dipping in $50 \mathrm{~mL} 0.9 \%$ saline. To quantify transconjugant formation in biofilms, biofilms were stained with Syto 62 (1:1000 dilution) directly on slides and images were collected by CLSM as described above. Eight images per treatment were analyzed using NIH ImageJ. Cells in microscopic images were analyzed by measuring the percent area covered by transconjugant cells and all cells to yield percentages of green fluorescing cells (transconjugants) within the total cells.

\subsubsection{Cell size measurement at different growth phases}

P. putida BBC443 and P. putida ATCC12633 were grown to early exponential (6.5 to $7.5 \mathrm{~h})$ and late stationary $(144 \mathrm{~h})$ growth phases. Cells were spun down at $7000 \mathrm{~g}$ for $5 \mathrm{~min}$, the supernatants were discarded, and the cell pellets were stained with Syto 62 for $20 \mathrm{~min}$ in dark. Cells were washed twice with $0.9 \%$ saline. Ten to fifteen images were collected using CLSM. Fifty cells of each the donor and recipient strain were measured by NIH ImageJ to obtain the cell size at early exponential and late stationary growth phases. Using these values, the average cell size at different growth phases of donor and recipient strains was calculated.

\subsubsection{DNA extraction, primers and polymerase chain reactions (PCR)}

DNA extraction from cell cultures of plasmid donor strain grown to early exponential $(6.5 \mathrm{~h})$ and late stationary growth phases (144 h) was performed using a GeneElute Bacterial Genomic DNA kit (Sigma-Aldrich) following the manufacturer's instructions. PCR was used to amplify portions (200 bp) of the 16S rRNA and traA genes. 
The primer sequences used to amplify $16 \mathrm{~S}$ rRNA and traA genes (Greated et al., 2002) were FAGGGTGGTGGAATTCCTGT, R-AGCTGCGCCACTAAAATCTC and FACAGTACCCATCCGGTTCAA, R-GCTTGTTCCTGGGTGATGTT (designed in this work), respectively. The $50 \mu \mathrm{L}$ PCR reaction mixture contained $6 \mu \mathrm{L}$ of template DNA, MilliQ $\mathrm{H}_{2} \mathrm{O}, 1$ $\mu \mathrm{L}$ of both the forward and reverse primer (primers working concentration to amplify was 25 $\mu \mathrm{M}), 0.6875 \mu \mathrm{L}$ BSA (20x) (New England BioLabs, MA, USA), $200 \mu \mathrm{M}$ of each dNTP (Bio Basics, ON, Canada), 2.5 units of Taq polymerase (New England BioLabs, MA, USA) in 10× Taq buffer (100 mM Tris hCl pH 9.0, 500 mM KCl, 15 mM MgCl2) (New England BioLabs, MA, USA).

PCR was performed according to the following program: denaturing at $96^{\circ} \mathrm{C}$ for $5 \mathrm{~min}$, thermocycling at $94^{\circ} \mathrm{C}$ for $1 \mathrm{~min}$, annealing temperature was $55^{\circ} \mathrm{C}$ for $1 \mathrm{~min}$ and decreased by $1^{\circ} \mathrm{C}$ in every cycle for 10 cycles, followed by 3 min elongation time at $72^{\circ} \mathrm{C}$. Additional 19 cycles were performed without decreasing the annealing temperature.

PCR products were loaded into a 1\% agarose gel with Red safe DNA gel stain (FroggaBio, ON, Canada) with a 100-bp ladder (Froggabio, ON, Canada), ran for 25 minutes at $100 \mathrm{~V}$, followed by visualization using Molecular Imager ChemiDoc ${ }^{\mathrm{TM}}$ XRS (Bio-Rad) to determine the presence of the PCR products.

\subsubsection{RNA isolation and cDNA synthesis}

Total RNA was extracted from the plasmid donor strain grown to early exponential phase (6.5 h), $48 \mathrm{~h}$ and late stationary phase (144 h) using the Fast prep system (MP Biomedicals, CA, USA) following the manufacturer's instructions. Twenty $\mu \mathrm{g}$ RNA was treated with DNase 1 
(Promega, Madison, USA). iScript cDNA synthesis kit (Bio-Rad,CA,USA) was used to synthesize cDNA from $1 \mu \mathrm{g}$ RNA.

\subsubsection{RT-PCR amplification}

RT-PCR was used to amplify segments (200 bp) of the $16 \mathrm{~S}$ rRNA gene and to detect the expression of traA genes. The $50 \mu \mathrm{L}$ PCR reaction mixture contained $0.2 \mu \mathrm{g}$ of template cDNA. Primer sequences, reagents and the program used to amplify 16S rRNA gene are mentioned above.

PCR reactions for $\operatorname{tra} A$ was performed according to the following program:

$96^{\circ} \mathrm{C}$ for $5 \mathrm{~min}$ (one cycle) followed by $94^{\circ} \mathrm{C}$ for $1 \mathrm{~min}, 55.3^{\circ} \mathrm{C}$ for $1 \mathrm{~min}, 72^{\circ} \mathrm{C}$ for $3 \mathrm{~min} .30$

cycles were performed. The PCR products were sent to Applied Genomics at SickKids in Toronto to perform gel electrophoresis. To confirm cDNA was synthesized and RNA samples were free from genomic DNA, no RT control (reverse transcriptase enzyme was not added during the cDNA synthesis), was used for all samples.

\subsubsection{Statistical analysis}

For batch culture experiments, one-way ANOVA with post hoc Tukey HSD test was used to determine the differences between different conditions. For biofilm experiments, t-test was used to determine the difference in transconjugant percentages in all cells. Data sets were considered to be significantly different at $\mathrm{p}<0.05$. 


\subsection{Optimization of RT-PCR to detect expression of traA in plasmid donor cells}

\subsubsection{Bacterial culture and growth condition}

Pseudomonas putida BBC443 carrying TOL plasmid pWWO (Christensen et al., 1998, Pei and Gunsch, 2009) was used as plasmid donor strain in this research project. 100\% LB medium amended with $50 \mu \mathrm{g} / \mathrm{mL}$ kanamycin was used to grow the donor cells at room temperature on a shaker at $390 \mathrm{rpm}$.

\subsubsection{RNA extraction and cDNA synthesis}

Total RNA was extracted from Pseudomonas putida BBC443 donor cells grown to different growth phases: early exponential $(6.5 \mathrm{~h})$, mid exponential $(24 \mathrm{~h})$, late exponential $(48 \mathrm{~h})$, mid stationary $(72 \mathrm{~h}$ ) and late stationary phase (144 h or day 6$)$ using the illustra RNA spin mini kit from GE healthcare life sciences ( ON, Canada) or FastPrep system (MP Biomedicals, CA, USA) following the manufacturer's instructions by using TRIzol (Thermo Scientific, ON, Canada). For the Fast prep system, twenty $\mu \mathrm{g}$ RNA was treated with DNase 1 (Promega, Madison, USA).

iScript cDNA synthesis kit (Bio-Rad, CA, USA ) was used to synthesize cDNA from $1 \mu \mathrm{g}$ RNA. cDNA was quantified by NanoDrop (Implen, Munchen, Germany).

\subsubsection{RT-PCR amplification}

RT-PCR was used to amplify segments (200 bp) of the $16 \mathrm{~S}$ rRNA and to detect the expression of $\operatorname{tra} \mathrm{A}$ genes. Primer sequences are mentioned in section 3.1.7. To optimize the reaction, $50 \mu \mathrm{L}$ PCR reaction mixture containing $0.1,0.2,0.4,0.8$, or $1.5 \mu \mathrm{g}$ of template cDNA was used. Other reagents are mentioned in section 3.1.7. 
PCR for $16 \mathrm{~S}$ rRNA was performed according to the following program: denaturing at $96^{\circ} \mathrm{C}$ for 5 min, thermocycling at $94^{\circ} \mathrm{C}$ for $1 \mathrm{~min}$, annealing temperature was $55^{\circ} \mathrm{C}$ for $1 \mathrm{~min}$ and decreased by $1^{\circ} \mathrm{C}$ in every cycle for 10 cycles, followed by 3 min elongation time at $72^{\circ} \mathrm{C}$. Additional 19 cycles were performed without decreasing the annealing temperature.

PCR reactions for $\operatorname{traA}$ gene was performed according to the above program that used to amplify 16S rRNA gene. A PCR program used to amplify traA is described in section 3.1.9.

RT-PCR $(10 \mu \mathrm{L})$ products were loaded into a $1 \%$ agarose gel with ethidium bromide stain (FroggaBio, ON, Canada) with a 100 bp ladder (Froggabio, ON, Canada), ran for 25 minutes at $100 \mathrm{~V}$, followed by visualization using Molecular Imager ChemiDoc ${ }^{\mathrm{TM}}$ XRS (Bio-Rad, CA, USA) to determine the presence of the RT-PCR products.

\subsection{Effect of nutrient concentrations on the determination of minimum inhibitory concentration of antibiotics}

\subsubsection{Bacterial strains, growth media and inoculum preparation}

Pseudomonas putida ATCC12633 and P. putida BBC443 (carrying TOL plasmid pWWO which contains a kanamycin resistance gene) (Christensen et al., 1998, Pei and Gunsch, 2009) were used for this study. (Details mentioned in section 3.1.1). To prepare 100\%, 50\% and 10\% Lysogeny Broth (LB), 20 g, 10 g, and 2 g LB broth powder (Bio Basics, ON, Canada) was added to $1 \mathrm{~L}$ deionized water, respectively.

To obtain inocula of $P$. putida BBC443, a volume $(40 \mathrm{~mL})$ of $100 \%$ or $50 \%$ LB broth was amended with $50 \mu \mathrm{g} / \mathrm{mL}$ kanamycin and added to $50 \mathrm{~mL}$ Falcon tubes. LB broth (10\%) was not amended with kanamycin as the growth of $P$. putida BBC443 was not detected after overnight incubation when amended with kanamycin. The three different concentrations of LB broth were 
inoculated with $P$. putida BBC443. Tubes were incubated on a shaker for $16-20 \mathrm{~h}$ at $320 \mathrm{rpm}$ at room temperature until the optical density $\left(\mathrm{OD}_{600}\right)$ reached 0.4 . These cultures were used to obtain $10^{5} \mathrm{CFU} / \mathrm{mL}$ as inoculum for MIC experiments. Kanamycin was used to grow P. putida BBC443 because resistance is encoded on the plasmid pWWO. $P$. putidaATCC12633 cultures were prepared as described for P. putida BBC443, without the addition of kanamycin.

\subsubsection{Antibiotics}

MICs of kanamycin, gentamicin, rifampicin and tetracycline were measured for the two Pseudomonas strains at different nutrient concentrations. Kanamycin is an aminoglycoside antibiotic for which resistance was encoded on plasmid pWWO, carried by $P$. putida BBC443. Gentamicin is an antibiotic in the same class as kanamycin, but the donor strain does not carry gentamicin resistance determinants. Rifampicin resistance is encoded on the P. putida BBC443 chromosome. Tetracycline resistance was neither plasmid- nor chromosomally encoded, but this antibiotic is widely used in human and veterinary medicines and distributed in the environment (Auerbach et al., 2006). Antibiotic stock solutions were made according to Andrews (2001) using powder of the antibiotics purchased from Bio Basics, ON, Canada. To prepare a stock solution, a weighed amount of the antibiotic powder was mixed with a volume of autoclaved milliQ $\mathrm{H}_{2} \mathrm{O}$. The prepared antibiotics were transferred into sterile $1.5 \mathrm{~mL}$ microcentrifuge tubes and stored at $-20^{\circ} \mathrm{C}$ (Andrews, 2001) until further use.

\subsubsection{Determination of the minimal inhibitory concentration (MIC)}

Overnight culture $\left(10^{5} \mathrm{CFU} / \mathrm{mL}\right)$, a specific volume of $100 \% \mathrm{LB}$ broth, a specific volume of antibiotic stock solution, and a specific volume of autoclaved deionized water (for 10\% and 50\% 
LB) were added in a $13 \mathrm{~mL}$ test tube to obtain total volume of $5 \mathrm{~mL}$. Each treatment was carried out in triplicate. The test tubes were incubated on a shaker for $18-24 \mathrm{~h}$ at $320 \mathrm{rpm}$ at room temperature. At the end of the incubation period, the OD (at $600 \mathrm{~nm}$ ) of the trials was measured. The lowest concentration of antibiotic at which bacterial growth was inhibited was determined as the minimal inhibitory concentration of that antibiotic. The experiment was carried out in $10 \%$, $50 \%$, and $100 \%$ LB broth concentrations to determine the MIC for each of the antibiotics.

The positive (no antibiotic) control for the experimental trials consisted of the appropriate amounts of $100 \%$ LB broth, deionized water (only for $10 \%$ and $50 \%$ LB conc.), and an overnight culture to obtain $5 \mathrm{~mL}$ total volume. The negative control (no overnight culture) contained appropriate amounts of $100 \%$ LB broth, deionized water (only for $10 \%$ and $50 \%$ LB concentrations) and an antibiotic to obtain $5 \mathrm{~mL}$ total volume.

\subsubsection{Determination of minimum bactericidal concentration (MBC)}

To determine minimum inhibitory concentration (MBC) of the antibiotics $100 \%$ LB was used. The experimental test tubes that were used for MIC experiments were also used to determine the MBC. After incubating for $24 \mathrm{~h}$ at room temperature, the OD was measured for all tubes and the test tubes that had an OD value of zero were plated on $100 \%$ LB agar plates using the spot plate technique. After 3-4 days, the plates were observed for colony appearance. The lowest concentration of antibiotic at which no colony was observed was determined as the minimum bactericidal concentration of that antibiotic (Andrews, 2001). 


\subsubsection{Determination of minimum biofilm eradication concentration (MBEC)}

To determine the minimum biofilm eradication concentration for $P$. putida ATCC12633, the biofilms were grown for $48 \mathrm{~h}$ in 24 well plates at room temperature. To grow the biofilms 490 $\mu \mathrm{L} 100 \% \mathrm{LB}$ broth and $10 \mu \mathrm{L}$ overnight culture (OD was $~ 0.4$ ) were added into the wells. Every $24 \mathrm{~h}, 250 \mu \mathrm{L}$ medium was removed and fresh LB was added. After $48 \mathrm{~h}, 250 \mu \mathrm{L}$ of the LB medium was removed and fresh LB was added to the wells to adjust the volume. Each concentration of antibiotics was added to four different wells. Positive (LB broth, overnight culture) and negative controls (LB broth, lowest concentration of antibiotic) were also set up for each antibiotic. After addition of the antibiotic, biofilms were grown for an additional 18-20 h. After 18-20 h, almost all the liquid was removed from the wells. The wells were washed twice with $100 \mu \mathrm{L}$ of $0.9 \%$ saline to remove planktonic cells. Another $50 \mu \mathrm{L}$ of $0.9 \%$ saline was added in the wells, mixed thoroughly by pipetting and $5 \mu \mathrm{L}$ of the solution from each well was spot plated three times on LB agar plates. After incubation for 3-4 days at room temperature, LB plates were visually observed for bacterial growth. The lowest concentration of antibiotic at which no colony was observed on the plates was determined as the minimum biofilm eradication concentration of that antibiotic.

\subsubsection{Effect of cell number on MIC}

To detect the effect of cell number on MIC with varying nutrient concentrations, $10^{3}, 10^{5}$ or $10^{7}$ $\mathrm{CFU} / \mathrm{mL}$ of overnight culture, a specific volume of $100 \% \mathrm{LB}$ broth, a specific volume of antibiotic stock solution, and a specific volume of autoclaved deionized water (for $10 \%$ and $50 \%$ LB) were added in a $13 \mathrm{~mL}$ test tube to obtain total volume of $5 \mathrm{~mL}$. 


\subsubsection{Effect of $\mathbf{p H}$}

P. putida BBC443 cells were grown overnight with $100 \%, 50 \%$ and $10 \%$ LB. To determine the effect of $\mathrm{pH}$ on $\mathrm{MIC}$ of gentamicin, $10^{3} / 10^{5} / 10^{7} \mathrm{CFU} / \mathrm{mL}$ overnight culture, antibiotic (gentamicin), a specific volume of autoclaved deionized water (for 50\% and 10\% LB) and LB broth were added to get final volume $5 \mathrm{~mL}$. Cultures were incubated for $18 \mathrm{~h}$ on $320 \mathrm{rpm}$ shaker at room temperature. $\mathrm{pH}$ (Mettler Toledo, ON, Canada) was measured before and after $18 \mathrm{~h}$ incubation.

\subsubsection{Effect of DNA on MIC}

DNA was extracted (Sigma Aldrich, MO, USA) from $10^{7} \mathrm{CFU} / \mathrm{mL} P$. putida $\mathrm{BBC} 443$ grown with $100 \%$ LB. To determine the effect of DNA on MIC of gentamicin, $10^{3}$ and $10^{5} \mathrm{CFU} / \mathrm{mL}$ with $10 \%$ LB were tested.

$10^{3}$ or $10^{5} \mathrm{CFU} / \mathrm{mL}$, antibiotic concentrations $\left(0.2,0.4,0.8,1.5 \mu \mathrm{g} / \mathrm{mL}\right.$ ), $\mathrm{dH}_{2} \mathrm{O}$ (to dilute $\mathrm{LB}$ to $10 \%$ ), LB and extracted DNA (5 or $10 \mu \mathrm{g} / \mathrm{mL}$ ) were combined to a final volume of $5 \mathrm{~mL}$ in 13 $\mathrm{ml}$ tubes. The tubes were incubated for $18 \mathrm{~h}$ on $320 \mathrm{rpm}$ shaker at room temperature. Turbidity was measured after $18 \mathrm{~h}$.

\subsubsection{Effect of biomass on MIC}

To detect the effect of cell biomass, a culture grown to $10^{7} \mathrm{CFU} / \mathrm{mL}$ was boiled to inactivate cells for $25 \mathrm{~min} .10^{3}$ or $10^{5} \mathrm{CFU} / \mathrm{mL}$, antibiotic concentrations $(0.2,0.4,0.8,1.5 \mu \mathrm{g} / \mathrm{mL}), \mathrm{dH}_{2} \mathrm{O}$ (to dilute $\mathrm{LB}$ to $10 \%$ ), $\mathrm{LB}$ and biomass were combined to a final volume of $5 \mathrm{~mL}$ in $13 \mathrm{~mL}$ tubes. The tubes were incubated for $18 \mathrm{~h}$ on $320 \mathrm{rpm}$ shaker at room temperature. Turbidity was measured after $18 \mathrm{~h}$ incubation. 


\subsection{The effects of subinhibitory and minimum inhibitory concentrations of gentamicin on transconjugant formation in biofilms and plate matings}

\subsubsection{Bacteria strains and growth conditions}

A modified Pseudomonas putida BBC443 strain (Christensen et al., 1998, Pei and Gunsch, 2009) carrying a green fluorescent protein tagged derivative of TOL plasmid pWWO, which also carries a kanamycin resistance gene was used as a plasmid donor strain.

P. putida ATCC12633 was used as plasmid recipient strain. Details of these strains are mentioned in section 3.1.1.

Lysogeny broth (LB) (Bioshop Inc., ON, Canada) was used to grow the plasmid donor and recipient strains. For donor strain cultivation, kanamycin (Bioshop Inc., ON, Canada) was added to a final concentration of $50 \mu \mathrm{g} / \mathrm{mL}$. Cultures were grown at room temperature (RT) with shaking at $390 \mathrm{rpm}$ for $48 \mathrm{~h}$.

\subsubsection{Plasmid transfer in plate mating experiments in the presence of gentamicin} Plasmid donor $P$. putida BBC443 and recipient $P$. putida ATCC12633 were grown for $48 \mathrm{~h}$ prior to the set up of plate mating experiments with LB broth at room temperature with shaking (390 rpm). Donor cells were grown with $50 \mu \mathrm{g} / \mathrm{mL}$ kanamycin and also with combined $50 \mu \mathrm{g} / \mathrm{mL}$ kanamycin and $0.5 \times$ MIC concentration of antibiotic gentamicin for $48 \mathrm{~h}$. Also, donor cells grown with kanamycin and $0.5 \times$ MIC gentamicin, were additionally challenged with MIC gentamicin. Donor and recipient cell solutions were collected into a $1.5 \mathrm{~mL}$ vials and washed twice with $0.9 \%$ saline. Mixtures of the donor and recipient cells were spot-plated on LB plates (triplicate), LB + 0.5× MIC gentamicin (Bioshop, ON, Canada) and LB + MIC gentamicin plates 
(triplicate). The plates were incubated at room temperature. MICs of gentamicin for the plasmid donor and recipient were $1.5 \mu \mathrm{g} / \mathrm{mL}$ and $3.6 \mu \mathrm{g} / \mathrm{mL}$, respectively.

After $72 \mathrm{~h}$, entire mating patches were collected by scraping, resuspended in $0.9 \%$ saline, washed two times with $0.9 \%$ saline, and stained with Syto 62 (Invitrogen, MA, USA) for 20 min in the dark. Mating patch solutions were examined by CLSM. Images were analyzed using Image J. The abundance of transconjugants was expressed as a percentage of total cells.

\subsubsection{Plasmid transfer in biofilms in the presence of gentamicin (in 24 well plates)}

Plasmid recipient Pseudomonas putida ATCC12633 cells were grown overnight in LB medium to optical density (OD) of 0.4 . To grow the biofilms, $10^{5} \mathrm{CFU} / \mathrm{mL}$ of this culture was added together with $490 \mu \mathrm{L}$ LB to 24 well plates. Recipient biofilms were grown at RT for $48 \mathrm{~h}$ in 24 well plates in a stationary mode. Donor P. putida BBC443 cells were grown for $48 \mathrm{~h}$ with 50 $\mu \mathrm{g} / \mathrm{mL}$ kanamycin and also with combined $50 \mu \mathrm{g} / \mathrm{mL}$ kanamycin and $0.5 \times$ MIC concentration of antibiotic gentamicin.

Donor cells grown with only kanamycin $\left(10^{9} \mathrm{CFU} / \mathrm{mL}\right)$ (after washing with $0.9 \%$ saline) or kanamycin and $0.5 \times$ MIC concentration of gentamicin were added to the $48 \mathrm{~h}$ old recipient biofilms (in 3 different wells of 24 well plate). After addition of donor cells, $0.5 \times$ MIC gentamicin was added in the biofilms. Gentamicin was not added in the control biofilms. To check that donor cells alone do not fluoresce green, donor cells were added to 3 wells with LB and also with and without gentamicin (control).

After donor addition, $500 \mu \mathrm{L}$ of liquid from the wells was removed and fresh LB medium was added to the wells every $24 \mathrm{~h}$. Three days (72 h) after donor cell addition, $850 \mu \mathrm{L}$ liquid was removed from the wells in order to remove planktonic cells. Next, the biofilms were washed 
once with $100 \mu \mathrm{L} 0.9 \%$ saline. Then the biofilms were scraped and transferred to $1.5 \mathrm{~mL}$ vials containing $0.9 \%$ saline. The biofilms were stained, and microscopic images were obtained. Details of staining and microscopy are mentioned below.

\subsubsection{Staining and microscopy}

To quantify transconjugant formation in biofilms, biofilms were stained with Syto 62 (1:1000 dilution) for $20 \mathrm{~min}$ in the dark. Images were collected by CLSM using $488 \mathrm{~nm}$ and $633 \mathrm{~nm}$ laser lines to detect GFP and Syto 62, respectively, and analyzed using NIH ImageJ. The percent area covered by transconjugant cells and the total cells were determined to yield green fluorescing cells (transconjugants) as a percentage of total cells.

\subsubsection{Statistical analysis}

For batch culture and biofilm experiments, one way ANOVA with post hoc Tukey HSD test was used to determine the differences between different conditions. Data sets were considered to be significantly different at $\mathrm{p}<0.05$. 


\section{Chapter 4}

\section{Results}

\subsection{Effect of cell growth phases on transconjugant formation using planktonic cultures and in biofilms}

\subsubsection{Effect of cell growth phases on plasmid transfer in plate matings using planktonically grown cells}

Growth curves constructed for donor and recipient strains showed that the plasmid donor and recipient cells reached the early exponential growth phase after $6.5-7.5 \mathrm{~h}$ and the late stationary growth phase at $144 \mathrm{~h}$ (Figure 4.1 and Figure 4.2). The donor and recipient growth curves did not follow a typical growth curve pattern. After an initial rapid increase in cell number, the $\mathrm{CFU} / \mathrm{mL}$ decreased and then plateaued. The CFU/mL of plasmid donor cells at $119.5 \mathrm{~h}$ and $169 \mathrm{~h}$ was $2.6 \times 10^{8}$ and $1.5 \times 10^{8}$, respectively. The $\mathrm{CFU} / \mathrm{mL}$ of plasmid recipient cells at $147.5 \mathrm{~h}$ and 171.25

h CFU/mL was $2.6 \times 10^{8}$ and $2.2 \times 10^{8}$, respectively. Since the growth curves of our strains do not follow a typical pattern, we chose to assign the term "late stationary phase" to the phase of growth at $144 \mathrm{~h}$ or later. Finkel (2006) discussed the phenomenon of long term stationary phase cultures. After the death phase, survivor cells can be maintained for months in long term stationary phase conditions. 


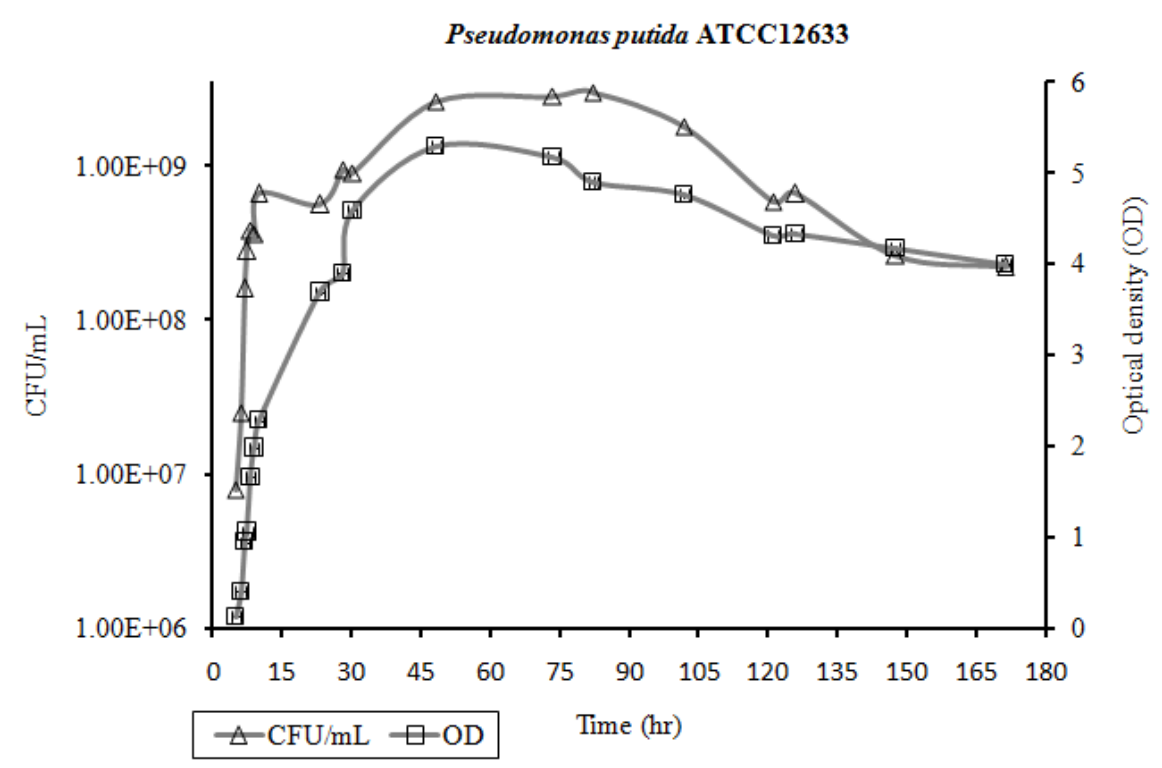

Figure 4.1. Growth curve of the plasmid recipient strain Pseudomonas putida ATCC12633. Optical density reading was obtained at $600 \mathrm{~nm}$ wavelength.

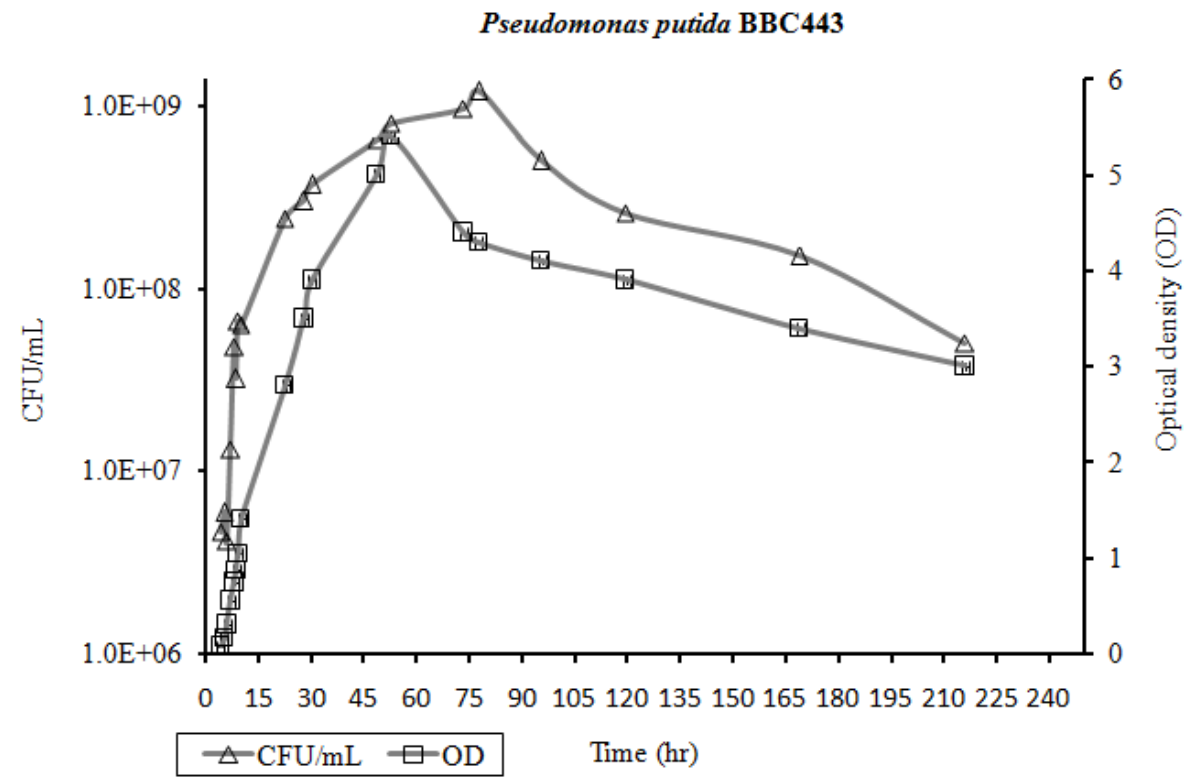

Figure 4.2. Growth curve of the plasmid donor strain Pseudomonas putida BBC443. Optical density reading was obtained at $600 \mathrm{~nm}$ wavelength. 
The expression of GFP was repressed in the plasmid donor cells due to the action of lacIq gene. Figure 4.3, shows no detection of GFP in P. putida BBC443 by confocal laser scanning microscopy.

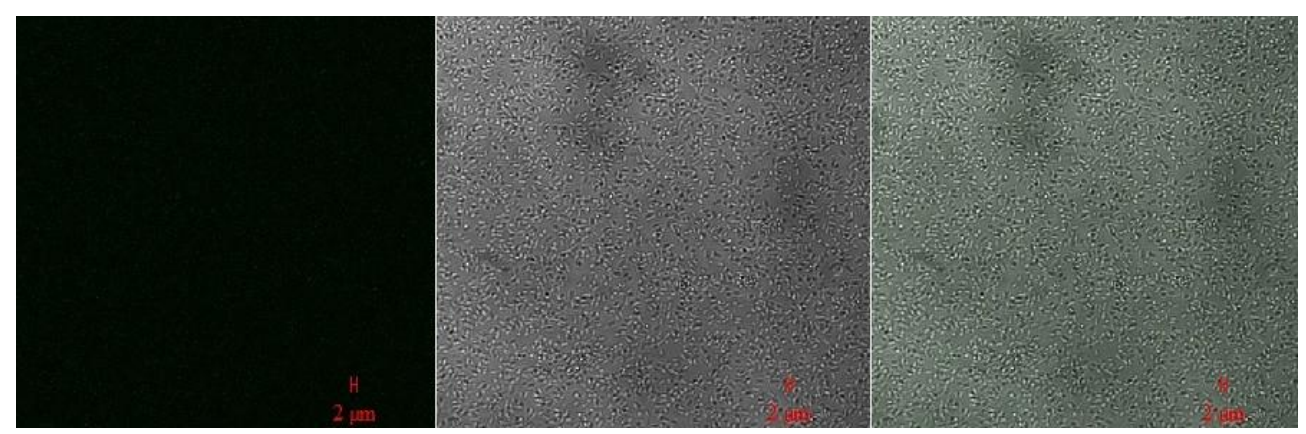

Figure 4.3. Microscopic image of plasmid donor Pseudomonas putida BBC443 cells. Donor contains the $\operatorname{lacl}^{q}$ repressor gene on its chromosome, which represses the expression of green fluorescence in donor cells.

Quantitative analysis (Table 4.1) of transconjugant cells and total cells derived from microscopic images (Figure 4.4 and Figure 4.5) followed by statistical analysis revealed that the transconjugants expressed as a percentage of all cells were the highest when both plasmid donor and recipient cells were harvested from the late stationary phase (Figure 4.5), whereas the lowest percentage of transconjugants was detected when the plasmid donor cells were grown to early exponential phase and the recipient cells were harvested from the late stationary phase (Table 4.1). 
Table 4.1. Transconjugants in mating patches as a percentage of total cells.

\begin{tabular}{|l|l|l|}
\hline Condition & $\begin{array}{l}\text { Different growth phases of plasmid donor and } \\
\text { recipient strains }\end{array}$ & Percentage of pWWO \\
transconjugants in total cells \\
\hline A & $\begin{array}{l}\text { Plasmid donor and recipient cells were grown } \\
\text { to early exponential phase }\end{array}$ & $8.0 \pm 3.0 \%$ \\
\hline B & $\begin{array}{l}\text { Plasmid donor and recipient cells were grown } \\
\text { to late stationary phase }\end{array}$ & $20.0 \pm 7.6 \%$ \\
\hline C & $\begin{array}{l}\text { Plasmid donor cells were grown to early } \\
\text { exponential phase and recipient cells were } \\
\text { grown to late stationary phase }\end{array}$ & $2.1 \pm 1.0 \%$ \\
\hline D & $\begin{array}{l}\text { Plasmid donor cells were grown to late } \\
\text { stationary phase and recipient cells were } \\
\text { grown to early exponential phase }\end{array}$ & $7.3 \pm 2.5 \%$ \\
\hline
\end{tabular}

When both the donor and recipient cells were harvested from the early exponential phase, the percentage of transconjugants $(8.0 \pm 3.0 \%)$ was significantly lower (Figure 4.6) than when both the plasmid donor and recipient cells were harvested from the late stationary phase $(20.0 \pm 7.6 \%$; Figure 4.5, Table 4.1). However, this result $(8.0 \pm 3.0 \%)$ was not significantly different from that obtained when the plasmid donor was grown to late stationary phase and the plasmid recipient

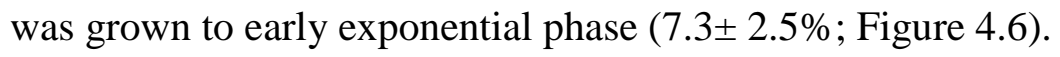



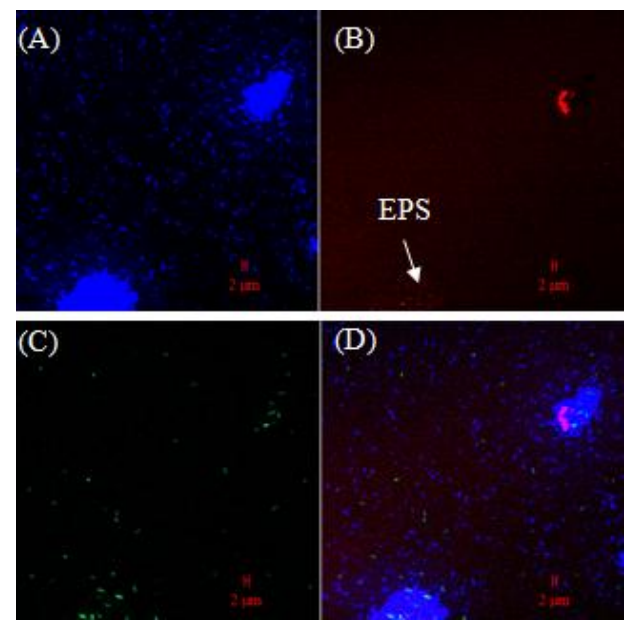

Figure 4.4. Microscopic images of plate mating patch of planktonically grown cultures (donor and recipient cells were grown to early exponential growth phase). (A) All cells were visualized with Syto 62 (blue), (B) EPS bound Con A-TRITC (red), (C) Transconjugants express GFP (green), (D) Overlay of all images.

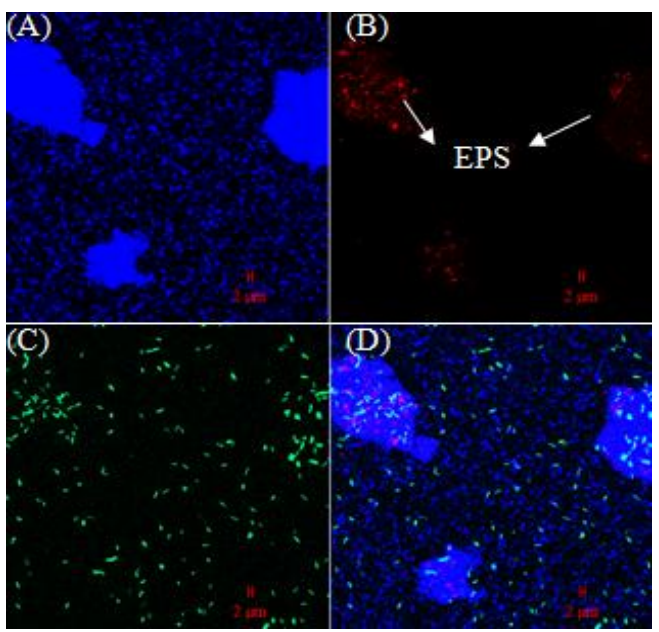

Figure 4.5. Microscopic images of plate mating patch of planktonically grown cultures (donor and recipient cells were grown to late stationary growth phase). (A) All cells were visualized with Syto 62 (blue), (B) EPS bound Con A-TRITC (red), (C) Transconjugants express GFP (green), (D) Overlay of all images.

Qualitative observations revealed that more EPS was present in the late stationary phase mating patch samples (Figure 4.5) than in those from the early exponential mating patch (Figure 4.4) and was mostly associated with cell clusters. 


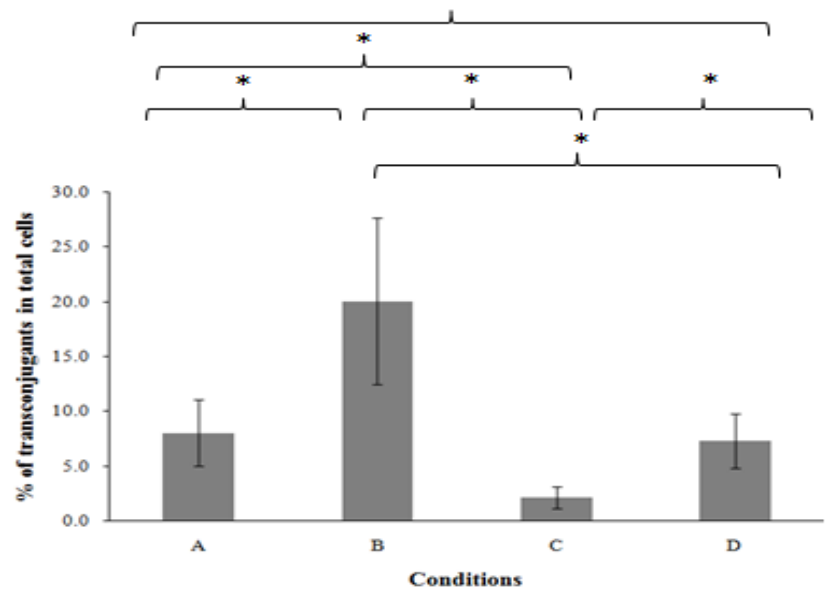

Figure 4.6. Data represent transconjugants expressed as a percentage of all cells for batch culture experiments. Condition A: plasmid donor and recipient cells were grown to early exponential phase, condition B: plasmid donor and recipient cells were grown to late stationary phase, condition $\mathrm{C}$ : plasmid donor cells were grown to early exponential phase and recipient cells were grown to late stationary phase, condition D: plasmid donor cells were grown to late stationary phase and recipient cells were grown to early exponential phase. Statistically significant groups are marked as *.

Qualitative observations also revealed that the plasmid donor strain culture at the late stationary phase exhibited increased cell aggregation and associated EPS than at the early exponential growth phase (Figure 4.7 and Figure 4.8, respectively).
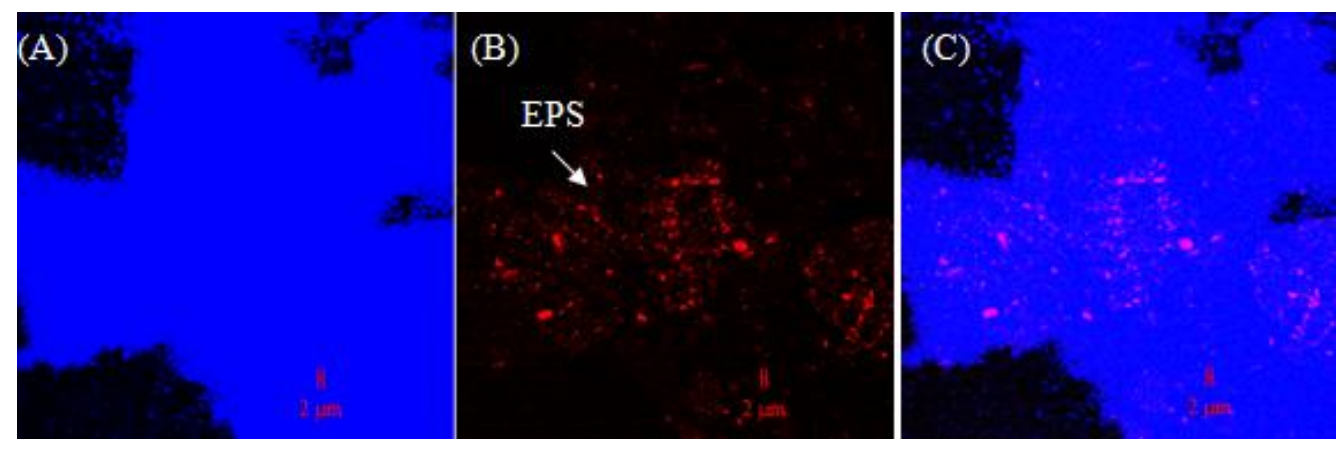

Figure 4.7. Microscopic image of planktonically grown donor cells to late stationary growth phase. Cells were stained with Syto 62 and Con A-TRITC. (A) All cells were visualized with Syto 62 (blue), (B) EPS bound ConA-TRITC (red), (C) Overlay of all images. 


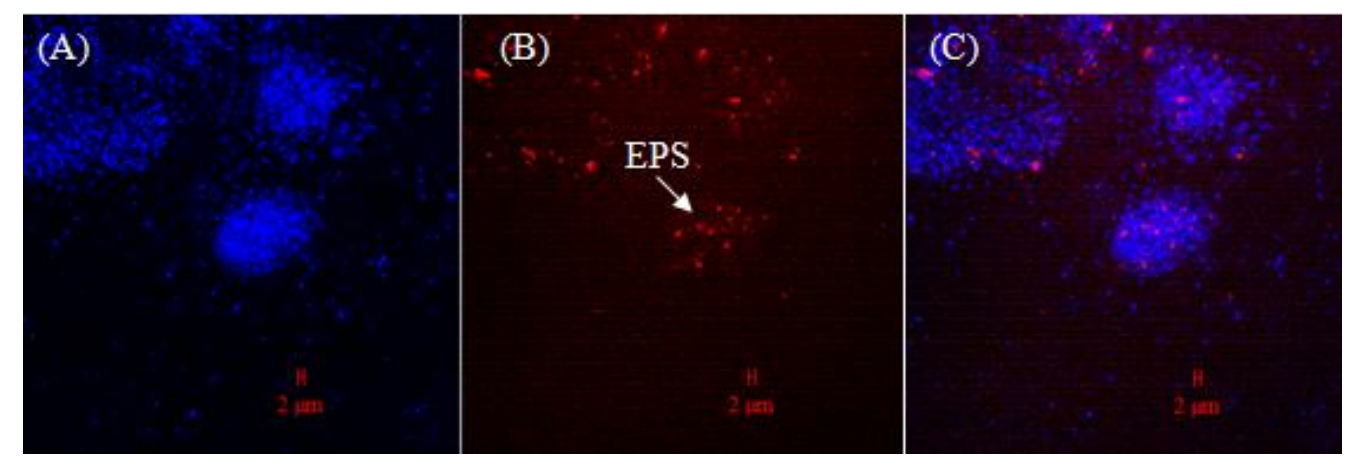

Figure 4.8. Microscopic image of planktonically grown donor cells to early exponential growth phase. Cells were stained with Syto 62 and ConA-TRITC. All cells were visualized with Syto 62 (blue), (B) EPS bound ConA-TRITC (red), (C) Overlay of all images.

While it was expected that the presence of EPS may obstruct conjugation by preventing direct cell to cell contact or may hinder the spread of donor cells in the inner layers of recipient biofilms (Merkey et al., 2011), our qualitative observations of EPS presence suggest that EPS does not impede gene transfer in plate matings. It was desired to find out if the higher percentage of transconjugants obtained from mating patches of both donor and recipient cells harvested from the stationary phase correlate with cell size. Results demonstrated that the cell length of both donor and recipient cells obtained from the early exponential phase was 2.4-2.6 fold greater than that of cells harvested from the late stationary phase (Table 4.2, Figure 4.9). 


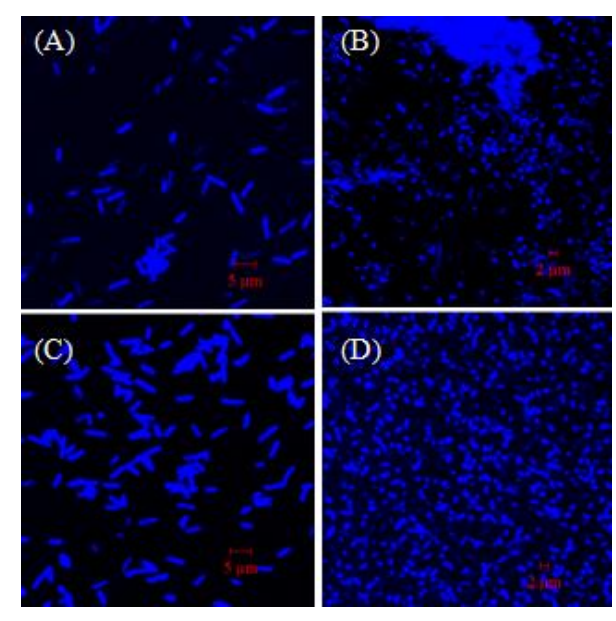

Figure 4.9. Microscopic images of plasmid donor and recipient cells grown to different growth phases. Cells were stained with Syto 62 (blue). (A) Donor cells grown to early exponential phase, (B) Donor cells grown to late stationary phase (C), Recipient cells grown to early exponential phase, (D) Recipient cells grown to late stationary phase.

Interestingly, the highest percentage of transconjugants was detected when both donor and recipient cells were harvested from the late stationary phase (Table 4.1), i.e. when cells were the smallest (Table 4.2).

Table 4.2. Average cell size at exponential and stationary growth phases of $P$. putida ATCC12633 and P. putida BBC443.

\begin{tabular}{|l|l|}
\hline Strains and growth phases & Average cell size $(\mu \mathrm{m})$ \\
\hline $\begin{array}{l}\text { Donor strain } P . \text { putida BBC443 at } \\
\text { exponential phase }\end{array}$ & $4.8 \pm 0.56$ \\
\hline $\begin{array}{l}\text { Donor strain } P . \text { putida BBC443 at stationary } \\
\text { phase }\end{array}$ & $2.0 \pm 0.36$ \\
\hline $\begin{array}{l}\text { Recipient strain P. putida ATCC12633 at } \\
\text { exponential phase }\end{array}$ & $4.9 \pm 0.81$ \\
\hline $\begin{array}{l}\text { Recipient strain P. putida ATCC12633 at } \\
\text { stationary phase }\end{array}$ & $1.9 \pm 0.35$ \\
\hline
\end{tabular}

In our study, the presence of the traA gene (encoding pilin synthesis, Greated et al., 2002) in both early exponential (6.5 h) and late stationary phase cells (144 h) (Figure 4.10) by PCR. 


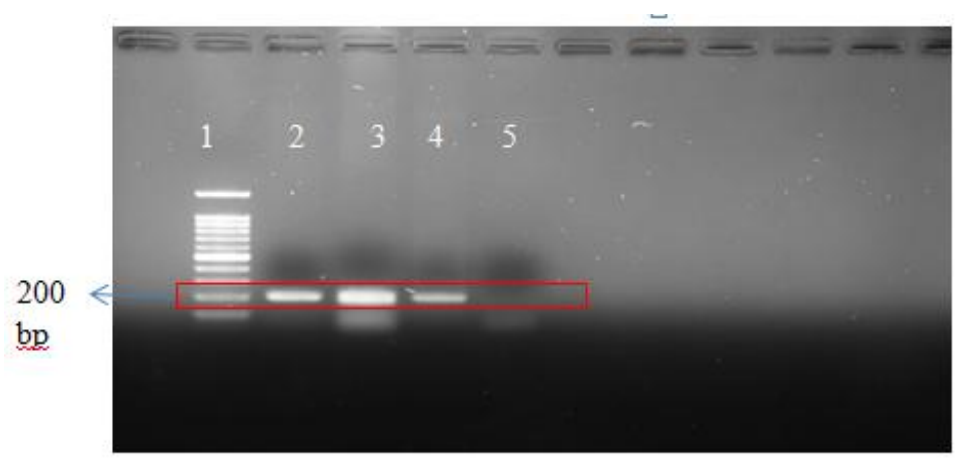

Figure 4.10. Agarose gel showing PCR-products of the traA gene (200 bp) Lane 1: marker, lane 2: positive control (PCR product for DNA extracted from donor strain P. putida BBC443 overnight culture), lane 3: PCR product for DNA extracted from donor strain P. putida BBC443 grown to early exponential growth phase, lane 4: PCR product for DNA extracted from donor strain $P$. putida BBC443 grown to late stationary growth phase, lane 5: negative control (PCR product for DNA extracted from recipient strain $P$. putida ATCC12633 overnight culture).

Using RT-PCR we detected expression of 16S rRNA gene (Figure 4.11) in donor cells grown to early exponential phase $(6.5 \mathrm{~h})$, late exponential phase $(48 \mathrm{~h})$ and late stationary phase (144 h). Expression of $\operatorname{traA}$ (which encodes pilus biosynthesis) was detected in donor cells grown to early exponential phase $(6.5 \mathrm{~h})$ and late exponential phase $(48 \mathrm{~h})$, but not for donor cells grown to late stationary phase (144 h) (Figure 4.12). 

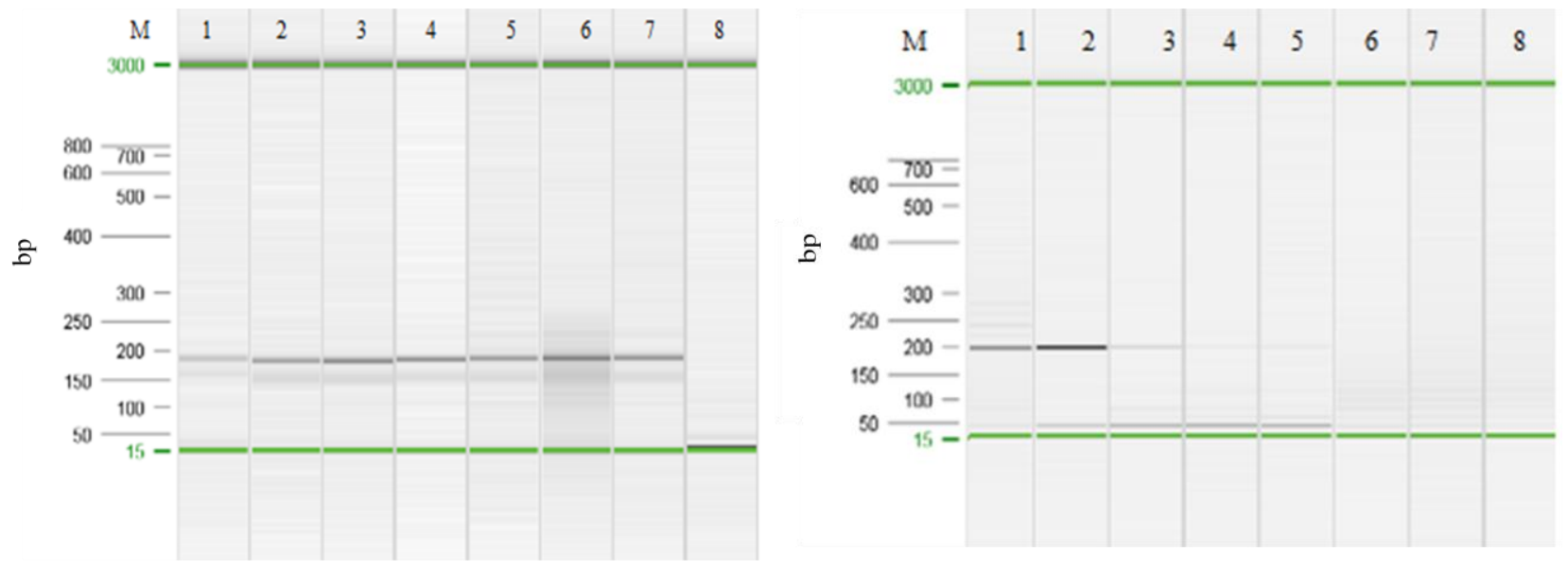

Figure 4.11. Gel electrophoresis for RT-PCR products (with 16S rRNA primers). RNA was extracted and cDNA was synthesized for donor cells harvested from different growth phases. Lane M: marker, lane 1: positive control (DNA), lanes 2 and 3: donor early exponential phase $(6.5 \mathrm{~h})$, lanes 4 and 5 : donor $48 \mathrm{~h}$, lanes 6 and 7: donor late stationary phase $(144 \mathrm{~h})$, lane 8 : negative control (cDNA reagents). Expected product size was $200 \mathrm{bp}$.

Figure 4.12. Gel electrophoresis for RT-PCR products (with traA primers). RNA was extracted and cDNA was synthesized for donor cells harvested from different growth phases. Lane M: marker, lane 1: positive control (DNA), lanes 2 and 3: donor early exponential phase $(6.5 \mathrm{~h})$, lanes 4 and 5: donor $48 \mathrm{~h}$, lanes 6 and 7: donor late stationary phase $(144 \mathrm{~h})$, lane 8: negative control (cDNA reagents). Expected product size was $200 \mathrm{bp}$.

The amplified products (200 bp) were not detected in negative controls that omitted reverse transcriptase (Figure 4.13 and Figure 4.14). 


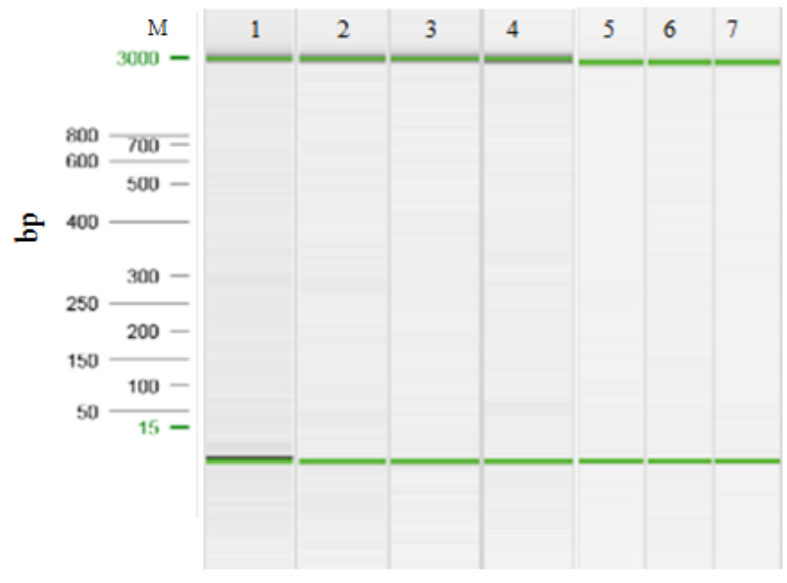

Figure 4.13. Gel electrophoresis for no RT control samples (with 16S rRNA primers). RNA was extracted and cDNA was synthesized for donor cells harvested from different growth phases without RT enzyme. Lane M: marker, lane 1: negative control (water as template), lanes 2 and 3: donor exponential phase $(6.5 \mathrm{~h})$, lanes 4 and 5: donor $48 \mathrm{~h}$, lanes 6 and 7: donor late stationary phase (144 h).

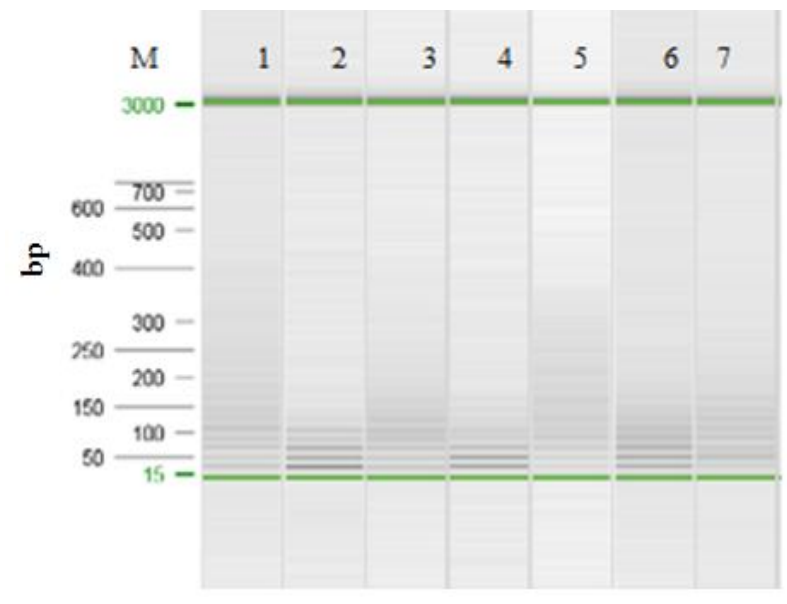

Figure 4.14. Gel electrophoresis for no RT control samples (traA primers). RNA was extracted and cDNA was synthesized for donor cells harvested from different growth phases without RT enzyme. Lane M: marker, lane 1: negative control (water as template), lanes 2 and 3: donor exponential phase $(6.5 \mathrm{~h})$, lanes 4 and 5: donor $48 \mathrm{~h}$, lanes 6 and 7: donor late stationary phase (144 h).

\subsubsection{Effect of plasmid donor growth phases on plasmid transfer in biofilms}

Quantitative analysis of transconjugant cells and total cells derived from microscopic images revealed that transconjugants expressed as the percentage of all cells were $0.11 \pm 0.1 \%$ and $0.20 \pm$ $0.2 \%$ when donor cells grown to early exponential growth phase and late stationary growth phase were added to $24 \mathrm{~h}$ old recipient biofilm, respectively (Figure 4.15 and Figure 4.16, respectively). 


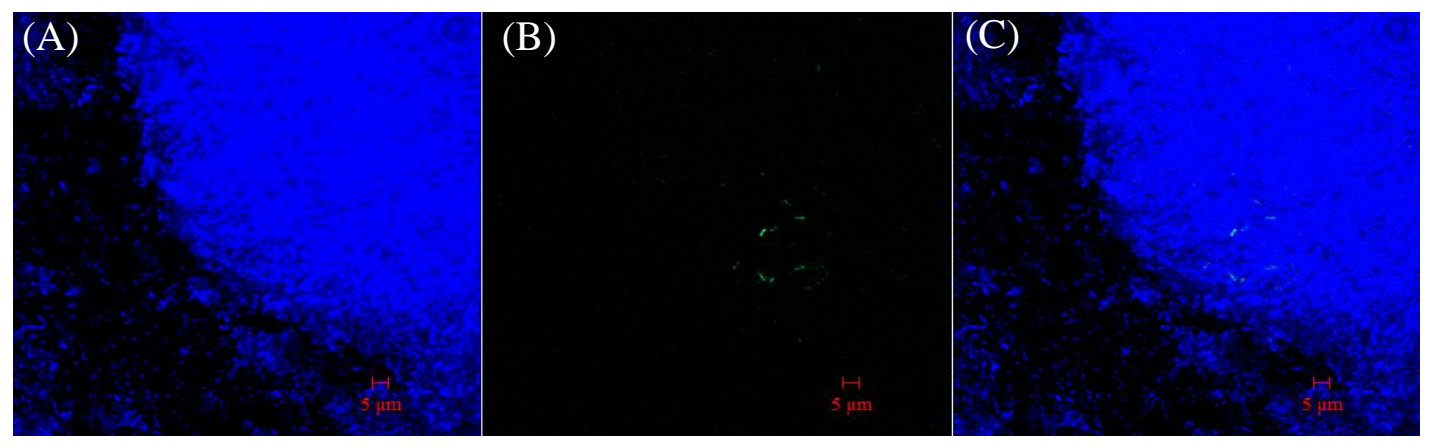

Figure 4.15. Microscopic image of transconjugants in recipient biofilms after plasmid donor cells grown to early exponential growth phase were added to $24 \mathrm{~h}$ old plasmid recipient biofilms. Image was taken after $72 \mathrm{~h}$ of donor cells addition. (A) All cells were visualized with Syto 62 (blue), (B) Transconjugants express GFP (green), (C) Overlay of all images.

However, these results were not significantly different following t-test analysis $(\mathrm{p}=0.27)$.

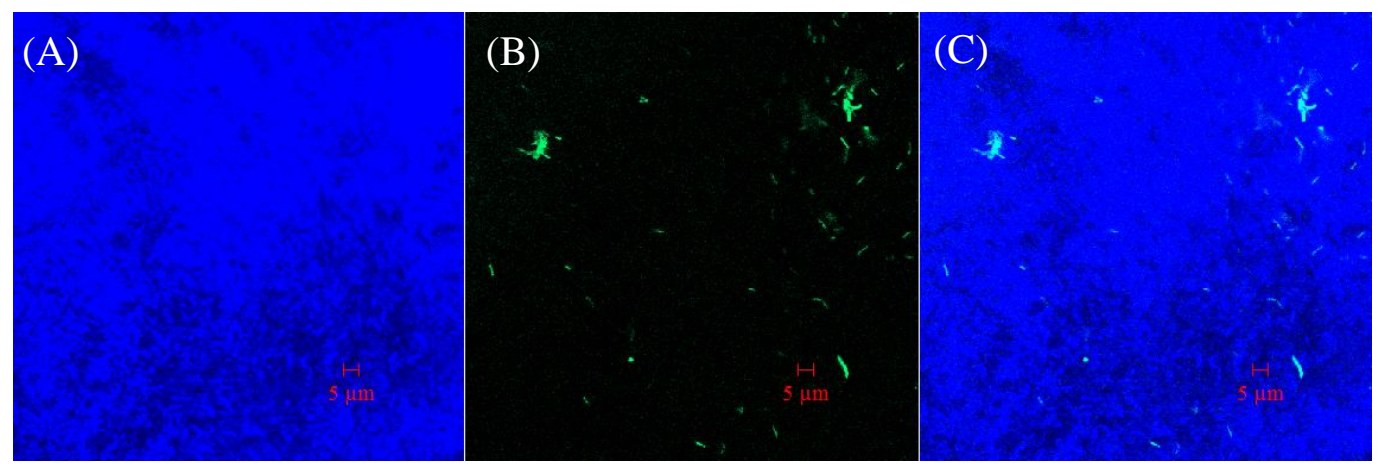

Figure 4.16. Microscopic image of transconjugants in the recipient biofilms after plasmid donor cells grown to late stationary growth phase were added to $24 \mathrm{~h}$ old plasmid recipient biofilms. Image was taken after $72 \mathrm{~h}$ of donor cells addition. (A) All cells were visualized with Syto 62 (blue), (B) Transconjugants express GFP (green) (C) Overlay of all images.

\subsection{Optimization of RT-PCR to detect expression of $\operatorname{traA}$ in plasmid donor cells}

RNA was extracted from $P$. putida BBC443 cells grown to different growth phases using the mini kit from GE health sciences (Figure 4.17 and Figure 4.18). cDNA was synthesized and RTPCR reactions were performed to detect the presence of 16S rRNA and traA genes (Figure 4.19 and Figure 4.20, respectively). 


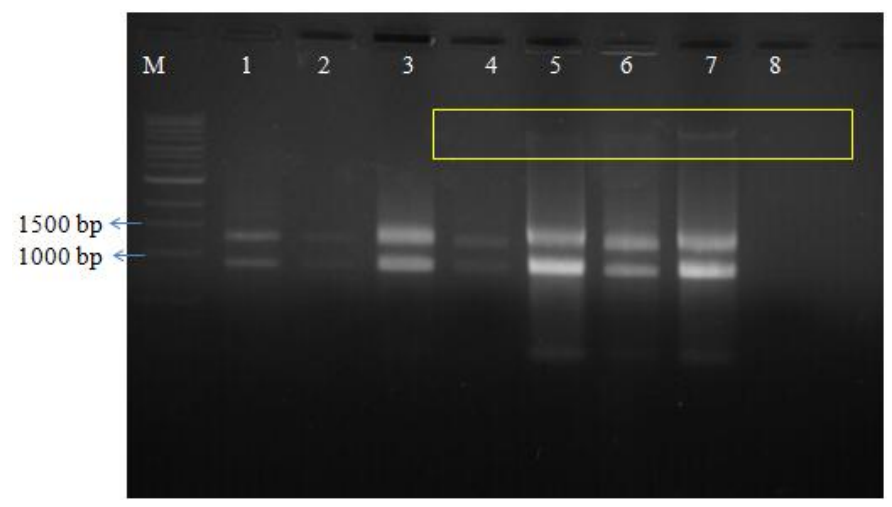

Figure 4.17. Gel electrophoresis for RNA samples. RNA was extracted from different growth phases of $P$. putida BBC443 donor cells. Illustra RNA spin mini kit from GE healthcare life sciences was used to extract RNA. Lane M: marker $(1 \mathrm{~kb})$, lanes 1-4: RNA was extracted from donor cells grown to early exponential phase (6.5 h, OD 0.6), lanes 5-7: RNA was extracted from donor cells grown to $24 \mathrm{~h}$, lane 8: negative control (H2O, no RNA).

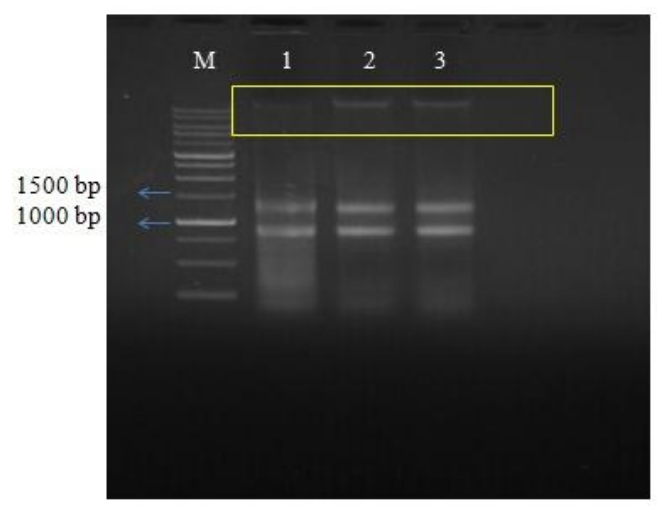

Figure 4.18. Gel electrophoresis for RNA samples. RNA was extracted from different growth phases of $P$. putida BBC443 cells. Illustra RNA spin mini kit from GE healthcare life sciences was used to extract RNA. Lane M: marker $(1 \mathrm{~kb})$, lane 1: RNA was extracted from donor cells grown to $72 \mathrm{~h}$, lanes 2 and 3: RNA was extracted from donor cells grown to stationary phase (day 6).

Initial experiments omitted a set up where no reverse transcriptase was used. This step is important to confirm cDNA was synthesized and RNA is free of genomic DNA (Park et al., 
2003). As shown in Figure 4.20 (lanes 4 and 5), traA was detected from donor cells grown to 72 h and day 6. For the mini kit, DNase 1 treatment was performed for $30 \mathrm{~min}$ and bands were visualized above the RNA (indicated by the yellow box in Figure 4.17 and Figure 4.18), suggesting the possibility of genomic DNA contamination. Therefore, RNA samples were treated with additional DNase 1 and RT-PCR reactions were performed.

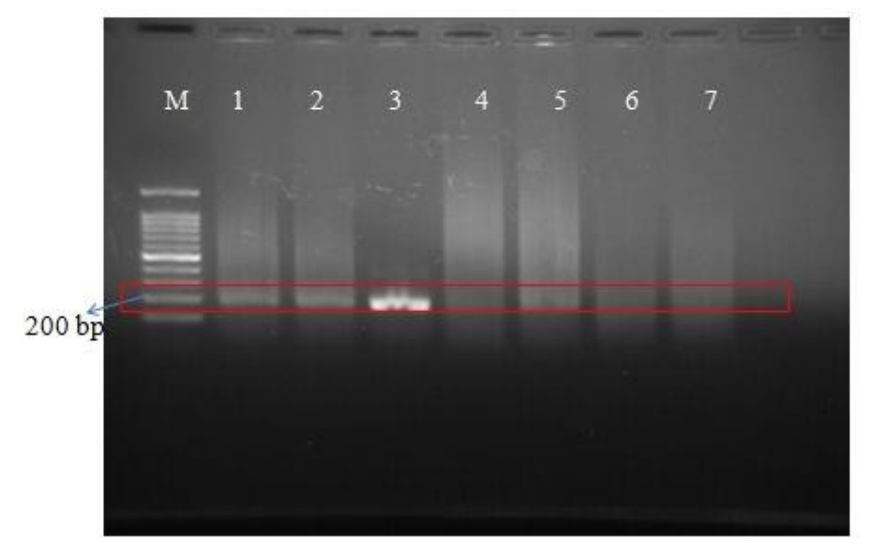

Figure 4.19. Gel electrophoresis for RT-PCR products. RT-PCR with cDNA (16S rRNA primers). RNA was extracted and cDNA was synthesized for donor cells harvested from different growth phases. Lane M: marker (100 bp), lane 1: positive control, lane 2: donor early exponential phase, lane 3: donor $24 \mathrm{~h}$, lane 4 : donor $72 \mathrm{~h}$, lane 5: donor late stationary phase (day 6), lane 6: negative control (PCR reagents + cDNA reagents), lane 7: negative control (PCR reagents+ MiliQ water).

After additional treatment with DNase 1, 16S rRNA was detected for donor cells grown to different growth phases, but $\operatorname{traA}$ was not detected by RT-PCR (Figures not shown). The presence of traA that was detected by RT-PCR from donor cells grown to $72 \mathrm{~h}$ and day 6 (Figure 4.20) might indicate contamination of genomic DNA in the RNA samples. 


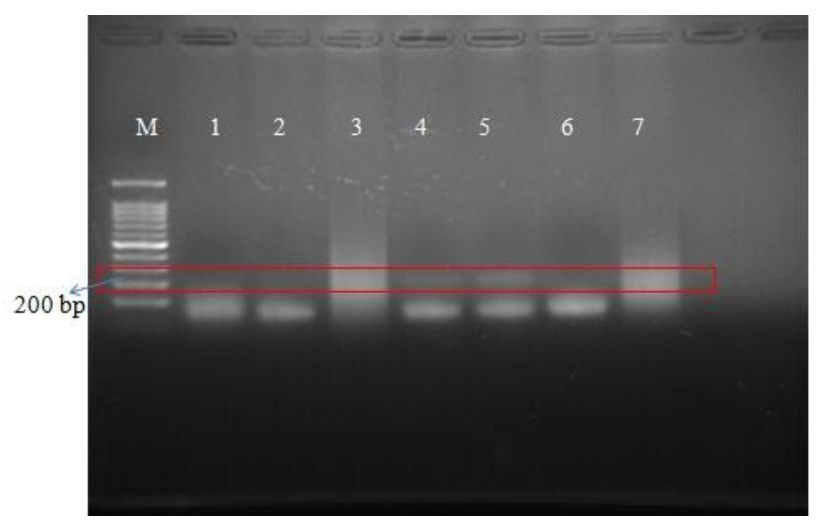

Figure 4.20. Gel electrophoresis for RT-PCR products. RT-PCR with cDNA (with traA primers) to detect the expression of $\operatorname{traA}$ in donor cells at different growth phases. RNA was extracted and cDNA was synthesized for donor cells harvested from different growth phases. Lane M: marker (100 bp), lane 1: positive control, lane 2: donor early exponential phase, lane 3: donor $24 \mathrm{~h}$, lane 4: donor $72 \mathrm{~h}$, lane 5: donor late stationary phase (day 6), lane 6: negative control (PCR reagents + cDNA reagents), lane 7: negative control (PCR reagents+ MiliQ water).

To optimize the RT-PCR method, RNA was extracted from different growth phases of donor cells by using FastPrep system (Figure 4.21) and cDNA was synthesized. The PCR program that was used to detect the presence of $16 \mathrm{~S}$ rRNA gene was also used to detect traA by using cDNA as template. Different cycle numbers (30, 40, and 42) and different amounts of cDNA (0.1, 0.2, $0.4,0.8$, or $1.5 \mu \mathrm{g}$ ) were used to amplify traA by RT-PCR (cDNA as template). Different cycle numbers and amount of cDNA were tested to optimize the RT-PCR protocol to detect the expression of traA in donor cells grown to different growth phases. But when cDNA was used as template, traA was not detected by this PCR program.

To optimize the annealing temperature for the traA primers gradient PCR was performed by using the donor colony cells directly (colony PCR) and DNA extracted from donor cells (Figure 4.22 and Figure 4.23). 


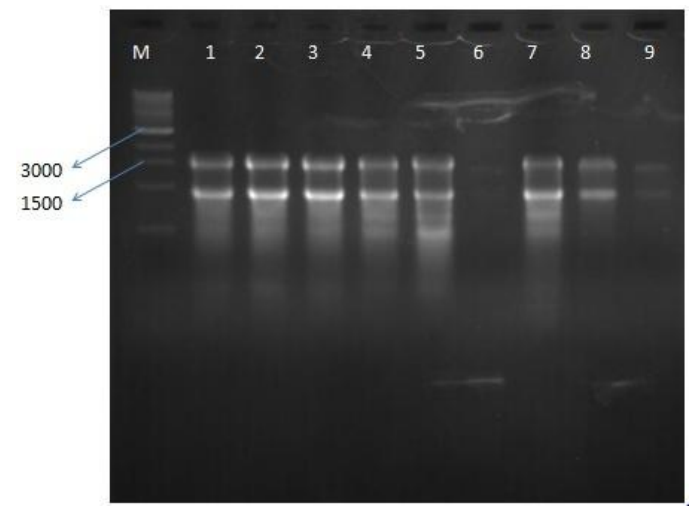

Figure 4.21. Gel electrophoresis for RNA samples. RNA was extracted from P. putida BBC443 donor cells grown to different growth phases. Lane M: marker (1 kb), lanes 1-3: donor RNA extracted from early exponential phase $(6.5 \mathrm{~h}$, OD 0.6), lanes 4-6: RNA extracted from donor cells grown to $48 \mathrm{~h}$, lanes 7-9: RNA was extracted from donor cells grown to late stationary phase (day 6).

For gradient PCR, the best results were obtained from $55.5^{\circ} \mathrm{C}, 56.75^{\circ} \mathrm{C}, 58^{\circ} \mathrm{C}$ and $59.25^{\circ} \mathrm{C}$ annealing temperatures (Figure 4.22 and 4.23).

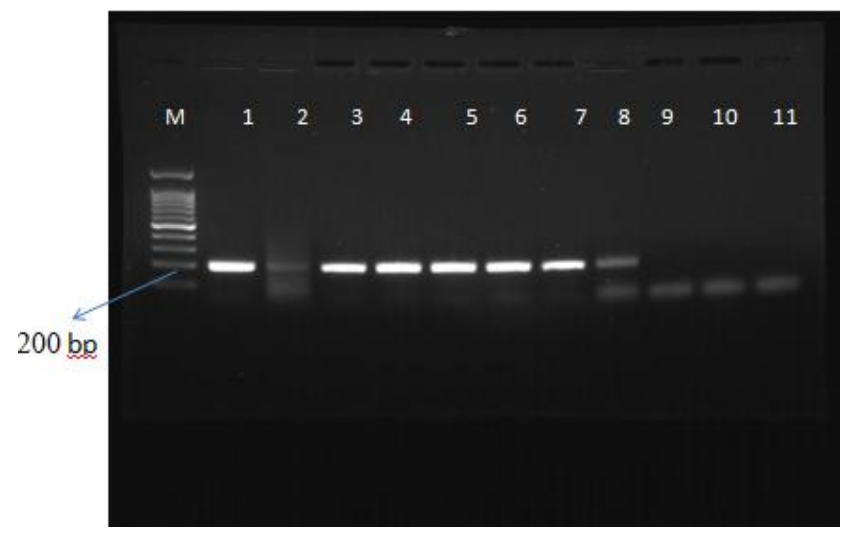

Figure 4.22. Gel electrophoresis for gradient PCR products. Gradient PCR with P. putida BBC443 colony cells. traA primers were used. Lane M: marker (100 bp), lane 1: annealing temperature $53^{\circ} \mathrm{C}$, lane 2: annealing temperature $54.25^{\circ} \mathrm{C}$, lane 3: annealing temperature $55.5^{\circ}$ $\mathrm{C}$, lane 4: annealing temperature $56.75^{\circ} \mathrm{C}$, lane 5 : annealing temperature $58^{\circ} \mathrm{C}$, lane 6 : annealing temperature $59.25^{\circ} \mathrm{C}$, lane 7 : annealing temperature $60.5^{\circ} \mathrm{C}$, lane 8: annealing temperature $63^{\circ}$ $\mathrm{C}$, lanes 9-11: negative control $(\mathrm{H} 2 \mathrm{O})$ at annealing temperatures $53^{\circ} \mathrm{C}, 55.5^{\circ} \mathrm{C}, 58^{\circ} \mathrm{C}$. 
Figure 4.22. shows the gel electrophoresis for gradient PCR products with P. putida BBC443 colony cells as template and Figure 4.23 shows the gel electrophoresis for gradient PCR products with DNA as template.

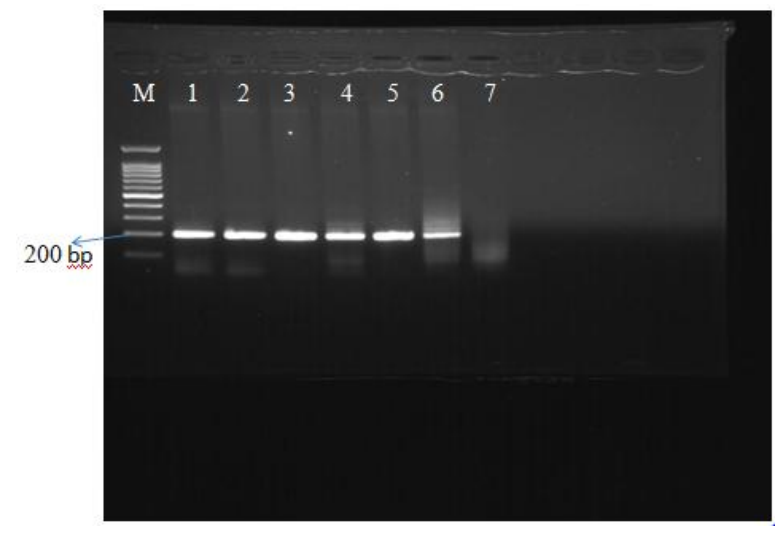

Figure 4.23. Gel electrophoresis for gradient PCR products. Gradient PCR with P. putida BBC443 DNA. traA primers were used. Left lane: marker (100 bp), lane 1: annealing temperature $53^{\circ} \mathrm{C}$, lane 2: annealing temperature $54.25^{\circ} \mathrm{C}$, lane 3 : annealing temperature $55.3^{\circ}$ $\mathrm{C}$, lane 4: annealing temperature $56.75^{\circ} \mathrm{C}$, lane 5 : annealing temperature $58^{\circ} \mathrm{C}$, lane 6 : annealing temperature $59.25^{\circ} \mathrm{C}$, lane 7: plasmid recipient DNA as negative control at annealing temperature $55.5^{\circ} \mathrm{C}$.

\subsection{Effect of nutrient concentrations on the determination of minimum inhibitory concentration of antibiotics}

In general, for both Pseudomonas strains, as the nutrient concentration decreased, the minimum inhibitory concentration for each antibiotic tested also decreased for both $P$. putida BBC443 and P. putida ATCC12633 (Table 4.3). 
Table 4.3. Determination of MIC of kanamycin (kan), gentamicin (gen), tetracycline (tet), and rifampicin (rif) for $P$. putida BBC443 and $P$. putida ATCC12633 with varying nutrient concentrations.

\begin{tabular}{|c|c|c|c|c|c|c|c|c|}
\hline \multirow{3}{*}{$\begin{array}{l}\text { Nutrient } \\
\text { concentrations } \\
(\% \text { LB })\end{array}$} & \multicolumn{8}{|c|}{ MIC at different nutrient concentrations $(\mu \mathrm{g} / \mathrm{mL})$} \\
\hline & \multicolumn{4}{|c|}{ P. putida BBC443 } & \multicolumn{4}{|c|}{ P. putida ATCC12633 } \\
\hline & kan & gen & rif & tet & kan & gen & rif & tet \\
\hline 100 & 101.1 & 1.5 & $>270$ & 2.0 & 2.3 & 3.6 & 11 & $2.0-2.2$ \\
\hline 50 & $\begin{array}{l}\text { Between } \\
20.1-21.0\end{array}$ & $<1.0$ & $>130$ & 1.6 & $\begin{array}{l}\text { Between } \\
0.8-1.5\end{array}$ & $<2.0$ & 4.8 & $1.8-2.0$ \\
\hline 10 & $<4.0$ & $\begin{array}{l}\text { Between } \\
0.2-0.4\end{array}$ & $>50$ & 1.2 & $<0.3$ & $\begin{array}{l}\text { Between } \\
0.5-0.8\end{array}$ & 3.8 & 1.2 \\
\hline
\end{tabular}

In order to test if increased cell number provides protective action against gentamicin, variable cell numbers were added as inocula. As shown in Table 4.4, while MIC increased with increasing cell numbers, for all cell numbers tested, MIC again decreased with decreasing nutrient concentration.

Table 4.4. Effect of different cell numbers on minimum inhibitory concentration of gentamicin for $P$. putida $\mathrm{BBC} 443$ with varying nutrient concentrations.

\begin{tabular}{|l|l|l|l|}
\hline \multirow{2}{*}{$\begin{array}{l}\text { Nutrient concentration } \\
(\% \mathrm{LB})\end{array}$} & \multicolumn{3}{|l|}{$\begin{array}{l}\text { MIC }(\mu \mathrm{g} / \mathrm{mL}) \text { at different nutrient concentrations with variable cell } \\
\text { numbers }\end{array}$} \\
\cline { 2 - 4 } & $10^{3} \mathrm{CFU} / \mathrm{mL}$ & $10^{5} \mathrm{CFU} / \mathrm{mL}$ & $10^{7} \mathrm{CFU} / \mathrm{mL}$ \\
\hline 100 & $<1.5$ & 1.5 & Between $4.5-5.0$ \\
\hline 50 & Between $0.4-0.8$ & $<1.0$ & $<3.0$ \\
\hline 10 & 0.2 & Between $0.2-0.4$ & Between $0.4-0.8$ \\
\hline
\end{tabular}

In order to detect if $\mathrm{pH}$ changes after incubation, and thus may influence MIC values, we measured $\mathrm{pH}$ when different cell numbers were added as inoculum (Table 4.5 and Table 4.6). For this study, $10^{3} \mathrm{CFU} / \mathrm{mL}$ or $10^{5} \mathrm{CFU} / \mathrm{mL}$ or $10^{7} \mathrm{CFU} / \mathrm{mL}$ was used as inoculum. The $\mathrm{pH}$ of the solutions prior to incubation was 6.9. $\mathrm{pH}$ was measured at the end of the experiments. At the MIC and above MICs of gentamicin no visible growth was observed and the $\mathrm{pH}$ was $6.8-7.0$ (Table 4.5). When gentamicin was added at below MIC level $(0.5 \times$ or near $0.5 \times$ minimum 
inhibitory concentration) turbidity or visible growth was observed and the $\mathrm{pH}$ was $7.1-7.7$ (Table 4.6).

Table 4.5. $\mathrm{pH}$ at minimum inhibitory concentrations of gentamicin for P. putida BBC443 with different cell numbers.

\begin{tabular}{|c|c|c|c|c|c|c|}
\hline \multirow{3}{*}{$\begin{array}{l}\text { Nutrient } \\
\text { concentrations } \\
(\% \text { LB })\end{array}$} & \multicolumn{6}{|c|}{ Cell numbers (CFU/mL) } \\
\hline & \multicolumn{2}{|c|}{$10^{3}$} & \multicolumn{2}{|l|}{$10^{5}$} & \multicolumn{2}{|l|}{$10^{7}$} \\
\hline & $\begin{array}{l}\text { Growth/no } \\
\text { growth }\end{array}$ & $\mathrm{pH}$ & $\begin{array}{l}\text { Growth/no } \\
\text { growth }\end{array}$ & $\mathrm{pH}$ & $\begin{array}{l}\text { Growth/no } \\
\text { growth }\end{array}$ & $\mathrm{pH}$ \\
\hline 100 & - & 6.8 & - & 6.9 & - & 6.9 \\
\hline 50 & - & 6.9 & - & 6.9 & - & 6.9 \\
\hline 10 & - & 6.9 & - & 7.0 & - & 6.9 \\
\hline
\end{tabular}

*growth (+), no growth (-)

Table 4.6. $\mathrm{pH}$ at $0.5 \times$ or near $0.5 \times$ minimum inhibitory concentrations of gentamicin for $P$. putida $\mathrm{BBC} 443$ with different cell numbers.

\begin{tabular}{|c|c|c|c|c|c|c|}
\hline \multirow{3}{*}{$\begin{array}{l}\text { Nutrient } \\
\text { concentrations } \\
(\% \text { LB })\end{array}$} & \multicolumn{6}{|c|}{ Cell numbers (CFU/mL) } \\
\hline & \multicolumn{2}{|c|}{$10^{3}$} & \multicolumn{2}{|l|}{$10^{5}$} & \multicolumn{2}{|l|}{$10^{7}$} \\
\hline & $\begin{array}{l}\text { Growth/no } \\
\text { growth }\end{array}$ & $\mathrm{pH}$ & $\begin{array}{l}\text { Growth/no } \\
\text { growth }\end{array}$ & $\mathrm{pH}$ & $\begin{array}{l}\text { Growth/no } \\
\text { growth }\end{array}$ & $\mathrm{pH}$ \\
\hline 100 & + & 7.2 & + & 7.5 & + & 7.4 \\
\hline 50 & + & 7.4 & + & 7.5 & + & 7.7 \\
\hline 10 & + & 7.1 & + & 7.1 & + & 7.5 \\
\hline
\end{tabular}

*growth (+), no growth (-)

In order to investigate whether DNA presence increases the MIC of gentamicin, we tested the effect of extracellular DNA using $P$. putida BBC443. To determine the effect of extracellular DNA, $10^{3}$ or $10^{5} \mathrm{CFU} / \mathrm{mL}$ was used as inoculum and $10 \% \mathrm{LB}$ was used as medium. When $10^{5}$ $\mathrm{CFU} / \mathrm{mL}$ was added as inoculum, the MIC of gentamicin for $10 \% \mathrm{LB}$ was higher than when $10^{3}$ $\mathrm{CFU} / \mathrm{mL}$ was added as inoculum (Table 4.4). Our results showed that when $5 \mu \mathrm{g} / \mathrm{mL}$ or 10 $\mu \mathrm{g} / \mathrm{mL}$ extracellular DNA was added, no visible growth was observed at MIC or higher gentamicin concentrations than MIC (e.g. $0.2,0.4,0.8$ and $1.5 \mu \mathrm{g} / \mathrm{mL}$ ) when $10^{3} \mathrm{CFU} / \mathrm{mL}$ was added as inoculum. When $10^{5} \mathrm{CFU} / \mathrm{mL}$ was added as inoculum visible growth was observed for 
higher MIC of gentamicin (e.g. 0.4, $0.6 \mu \mathrm{g} / \mathrm{mL}$ ) (Table 4.7). We also tested if biomass (biomass was heat inactivated cells and obtained by boiling the $P$. putida $\mathrm{BBC} 443$ cells) has a protective effect from gentamicin. When biomass was added, no growth was observed for higher concentrations than MIC for $10^{3} \mathrm{CFU} / \mathrm{mL}$ inoculum with $10 \% \mathrm{LB}$. Visible growth was observed at MIC and higher concentrations than MIC gentamicin when $10^{5} \mathrm{CFU} / \mathrm{mL}$ was added as inoculum (Table 4.8).

Table 4.7. Effect of extracellular DNA at either the MIC or above MIC of gentamicin for $P$. putida BBC443. $10^{3}$ or $10^{5} \mathrm{CFU} / \mathrm{mL}$ were used as inocula and $10 \% \mathrm{LB}$ was used as growth medium.

\begin{tabular}{|l|l|l|}
\hline \multirow{2}{*}{$\begin{array}{l}\text { Added DNA concentration } \\
(\mu \mathrm{g} / \mathrm{mL})\end{array}$} & Cell numbers \\
\cline { 2 - 3 } & $10^{3} \mathrm{CFU} / \mathrm{mL}$ & $10^{5} \mathrm{CFU} / \mathrm{mL}$ \\
\hline 5 & - & + \\
\hline 10 & - & + \\
\hline No DNA (control) & - & - \\
\hline
\end{tabular}

*growth (+), no growth (-)

Table 4.8. Effect of biomass at either the MIC or above MIC of gentamicin for P. putida BBC $443.10^{3}$ or $10^{5} \mathrm{CFU} / \mathrm{mL}$ were used as inocula and $10 \% \mathrm{LB}$ was used as medium.

\begin{tabular}{|l|l|l|}
\hline \multirow{2}{*}{ Biomass } & Cell numbers & $10^{5} \mathrm{CFU} / \mathrm{mL}$ \\
\cline { 2 - 3 } & $10^{3} \mathrm{CFU} / \mathrm{mL}$ & + \\
\hline $\begin{array}{l}10^{7} \mathrm{CFU} / \mathrm{mL} \text { (heat- } \\
\text { inactivated cells) was added }\end{array}$ & - & - \\
\hline $\begin{array}{l}\text { No biomass (heat inactivated } \\
\text { cells) was added (control) }\end{array}$ & - & - \\
\hline
\end{tabular}

*growth (+), no growth (-)

We also measured the MBC for kanamycin, gentamicin, rifampicin and tetracycline for $P$. putida BBC443 and P. putida ATCC12633 and MBEC for P. putida ATCC12633 with 100\% LB (Tables A2 and A3). The values of MBC and MBEC were higher than MIC values for all four antibiotics. 


\subsection{The effects of subinhibitory and minimum inhibitory concentrations of gentamicin on transconjugant formation in biofilms and plate matings}

In plate mating experiments, a higher abundance of transconjugants expressed as a percentage of total cells $(4.3 \pm 0.62 \%)$ was detected when the donor cells were exposed to $0.5 \times$ minimum inhibitory concentration of gentamicin for $48 \mathrm{~h}$ and then additionally challenged with gentamicin at MIC for $1 \mathrm{~h}$ and no gentamicin was added to the plate on which plate matings were carried out (Table 4.9). This result was significantly different from the negative control (donor cells were not exposed to gentamicin and no gentamicin was added to the LB plate), where transconjugants comprised $2.5 \pm 1.20 \%$ of total cells (Figure 4.24).

Table 4.9. Effect of gentamicin on transconjugant formation in plate mating experiment.

\begin{tabular}{|l|l|l|l|}
\hline Conditions & Donor exposure to gentamicin & $\begin{array}{l}\text { Mating on LB } \\
\text { plates-gentamicin } \\
\text { presence/absence }\end{array}$ & $\begin{array}{l}\text { Transconjugants } \\
(\% \text { of total } \\
\text { cells })\end{array}$ \\
\hline A (control) & None & None & $2.5 \pm 1.20$ \\
\hline B & $0.5 \times$ MIC $(48 \mathrm{~h})$ & None & $2.9 \pm 1.33$ \\
\hline C & $0.5 \times$ MIC $(48 \mathrm{~h})$ & $0.5 \times$ MIC & $3.5 \pm 0.99$ \\
\hline D & $0.5 \times$ MIC $(48 \mathrm{~h}), 1$ h challenge with MIC & MIC & $3.7 \pm 1.57$ \\
\hline E & None & $0.5 \times$ MIC & $3.8 \pm 1.61$ \\
\hline F & $0.5 \times$ MIC $(48 \mathrm{~h}), 1$ h challenge with MIC & None & $4.3 \pm 0.62$ \\
\hline
\end{tabular}

*To grow plasmid donor cells $50 \mu \mathrm{g} / \mathrm{mL}$ kanamycin was added in all conditions.

Statistical analysis revealed that all other conditions did not yield significantly different results (Figure 4.24). 

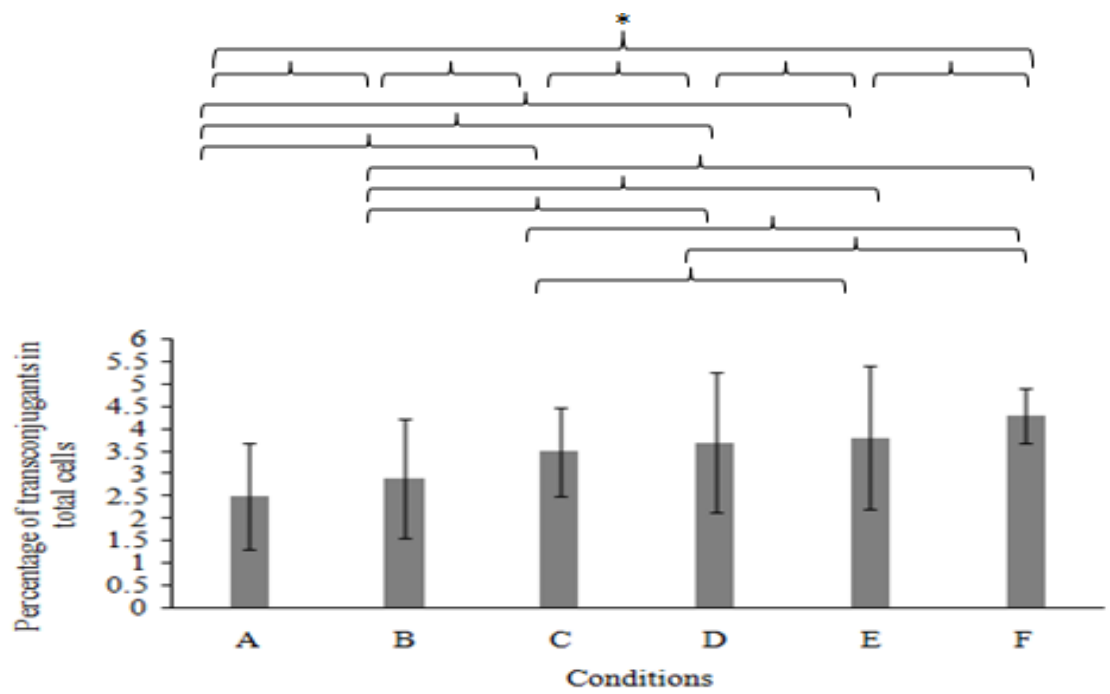

Figure 4.24. Data represent transconjugants expressed as percentage in total cells for batch culture experiments. Condition A: donor cells were not exposed to gentamicin and gentamicin was not added to the plate on which matings were carried out, condition B: donor cells were grown with $0.5 \times$ MIC gentamicin for $48 \mathrm{~h}$ and gentamicin was not added to the plate on which matings were carried out, condition C: donor cells were grown with $0.5 \times$ MIC gentamicin for $48 \mathrm{~h}$ and $0.5 \times$ MIC gentamicin was added to the plate on which matings were carried out, condition D: donor cells were grown with $0.5 \times$ MIC gentamicin for $48 \mathrm{~h}$, additionally challenged with MIC gentamicin for $1 \mathrm{~h}$ and MIC gentamicin was added to the plate on which matings were carried out, condition E: donor cells were not exposed to gentamicin and $0.5 \times \mathrm{MIC}$ gentamicin was added to plate on which matings were carried out, condition F: donor cells were grown with $0.5 \times$ MIC gentamicin for $48 \mathrm{~h}$, additionally challenged with MIC gentamicin for $1 \mathrm{~h}$ and gentamicin was not added to the plate on which matings were carried out. Statistically significant group is marked as *.

In biofilms, transconjugant formation was not enhanced in the presence of $0.5 \times$ gentamicin

(Table 4.10). The result was significantly different when the donor cells were grown with $0.5 \times$

MIC and 0.5× MIC gentamicin was added in the biofilms (percentage of transconjugants in the total cells was $0.014 \pm 0.01 \%$ ) and the control (gentamicin was not added in the biofilms, percentage of transconjugants in the total cells was $0.039 \pm 0.02 \%$ ) (Table 4.10, Figure 4.25). 
Table 4.10. Effect of $0.5 \times$ MIC of gentamicin on transconjugant formation in biofilms.

\begin{tabular}{|l|l|l|l|}
\hline Conditions & $\begin{array}{l}\text { Donor exposure to } \\
\text { gentamicin }\end{array}$ & $\begin{array}{l}\text { Mating in plasmid } \\
\text { recipient biofilms- } \\
\text { gentamicin } \\
\text { presence/absence }\end{array}$ & $\begin{array}{l}\text { Transconjugants (\% of } \\
\text { total cells) }\end{array}$ \\
\hline A & None & None & $0.037 \pm 0.02$ \\
\hline B & $0.5 \times$ MIC $(48 \mathrm{~h})$ & $0.5 \times$ MIC & $0.014 \pm 0.01$ \\
\hline C & $0.5 \times$ MIC $(48 \mathrm{~h})$ & None & $0.039 \pm 0.02$ \\
\hline
\end{tabular}

*To grow plasmid donor cells $50 \mu \mathrm{g} / \mathrm{mL}$ kanamycin was added in all conditions.

In comparison to the control (condition A, Table 4.10), transconjugant formation was not enhanced when the donor was exposed to $0.5 \times$ MIC of gentamicin (condition C, Table 4.10) or when both the donor and the mating mixture were exposed to $0.5 \mathrm{MIC}$ of gentamicin (condition B, Table 4.10). However, donor and mating patch exposure to 0.5 MIC (condition B) resulted in significantly decreased abundance of transconjugants (Figure 4.25).

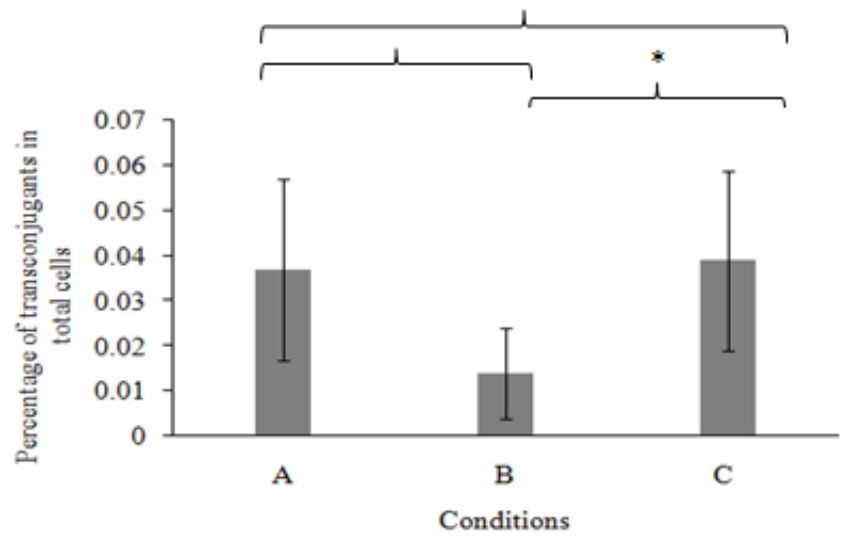

Figure 4.25. Data represent transconjugants expressed as percentage in total cells for biofilm experiments. Condition A: donor cells were not exposed to gentamicin and gentamicin was not added in the biofilms, condition B: donor cells were grown with $0.5 \times$ MIC gentamicin for $48 \mathrm{~h}$ and $0.5 \times$ MIC gentamicin was added in the biofilms, condition C: donor cells were grown with $0.5 \times$ MIC gentamicin for $48 \mathrm{~h}$ and no gentamicin was added in the biofilms. Statistically significant group is marked as *. 
Preliminary experiments indicate that transconjugant formation was enhanced when the donor cells were grown with $0.5 \times$ MIC of gentamicin and additionally challenged at MIC of gentamicin for $1 \mathrm{~h}$ and gentamicin at MIC was added to the biofilms in comparison to when donor cells were not grown with gentamicin but challenged with MIC of gentamicin prior to adding in the recipient biofilms and no gentamicin was added in the biofilms (Table 4.11).

Table 4.11. Effect of MIC of gentamicin on transconjugant formation in biofilms.

\begin{tabular}{|l|l|l|}
\hline $\begin{array}{l}\text { Plasmid donor exposure to } \\
\text { gentamicin }\end{array}$ & $\begin{array}{l}\text { Mating in recipient biofilms - } \\
\text { gentamicin presence / absence }\end{array}$ & $\begin{array}{l}\text { Transconjugants (\% of } \\
\text { total cells) }\end{array}$ \\
\hline $\begin{array}{l}0.5 \times \text { MIC }(48 \mathrm{~h}), \\
1 \mathrm{~h} \text { challenge at MIC }\end{array}$ & MIC & $0.90 \pm 0.69$ \\
\hline 1 h challenge at MIC & None & $0.03 \pm 0.03$ \\
\hline
\end{tabular}

*To grow plasmid donor cells $50 \mu \mathrm{g} / \mathrm{mL}$ kanamycin was added in all conditions.

Figure 4.26 shows the presence of a greater amount of transconjugants in biofilms exposed to MIC of gentamicin (A) in comparison to no exposure to gentamicin (B).
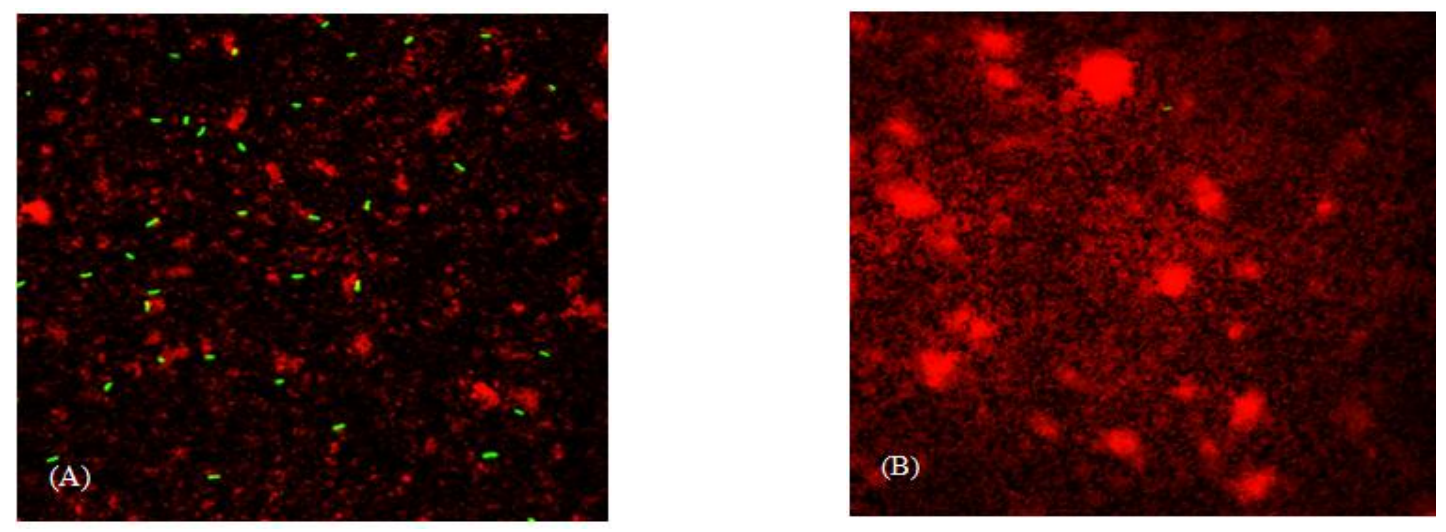

Figure 4.26. Microscopic images of biofilm cells exposed to MIC of gentamicin (A) and without exposure to gentamicin (B). Green cells represent transconjugant cells, red cells represent total cells. (63× magnification was used) 


\section{Chapter 5}

\section{Discussion}

\subsection{Effect of cell growth phases on transconjugant formation using planktonic cultures and in biofilms}

In this study, the effect of donor and recipient growth phases on transconjugant formation in plate matings using planktonically grown batch culture cells and biofilms was investigated.

\subsubsection{Effect of cell growth phases on plasmid transfer in plate matings using planktonically grown cells}

Our results showed that transconjugants expressed as a percentage of all cells was the highest when both plasmid donor and recipient cells were harvested from the late stationary phase (144 h; Table 4.1, Figure 4.6), when the cell size of both donors and recipients was smaller than that observed during the exponential growth phase (Table 4.2, Figure 4.9), whereas the lowest percentage of transconjugants was detected when the plasmid donor cells were grown to early exponential phase $(6.5-7.5 \mathrm{~h})$ and the recipient cells were harvested from the late stationary phase. The results did not support our hypothesis. Our hypothesis was the abundance of transconjugants will be higher in the exponential growth phase than in the stationary growth phase of the donor and recipient cells in plate matings.

Growth curves for the recipient and donor strains are shown in the Figures 4.1 and 4.2. In our study, the cell length of both donor and recipient cells obtained from the early exponential phase was 2.4-2.6 fold greater than that of cells harvested from the late stationary phase. When grown in batch culture, cells face nutritional limitation upon entry into the stationary phase (Gefen et al., 2014). When bacterial cells are subjected to nutrient limitation, the cell size becomes smaller, 
and cells become more resistant to environmental stress (Trevors, 2011, Kolter et al., 1993). Contrary to Seoane et al. (2011), who suggested that cell elongation may facilitate conjugation, Muela et al. (1994) observed the lowest values of plasmid transfer frequency when donor cells were obtained from the mid-exponential phase when the cell size of the plasmid donor cells was maximum. In their study, no significant differences in plasmid transfer frequency were detected along the growth phase of the recipient strains. The authors suggested that the energy available to donor cells may be involved in the processes of biosynthesis, thus hindering the plasmid transfer process. Conjugation is an energy dependent process as energy is required for DNA replication and protein synthesis in donor and recipient cells (Rittmann et al., 1995, Król et al., 2011). ATP may also be required for maintenance of sex pili on the cell surface (Yamamoto et al., 1981). In our study, the highest percentage of transconjugants was obtained when the plasmid donor and recipient cells were harvested from the late stationary phase and when the cell size of the plasmid donor and recipient was smaller. Because less energy was needed for cellular processes, we speculate that the energy available to the donor and recipient cells was used to facilitate plasmid transfer process in the stationary growth phase. In long term stationary phase, the expression of stress response genes is necessary for the survival of bacterial cells (Finkel, 2006). We speculate that in the late stationary growth phase genes (other than $t r a A$ ) involved in mating pair formation in plasmid donor and recipient cells may have been expressed, enhancing plasmid transfer and transconjugant formation.

The number of transconjugants formed may be also influenced by the physiological status of the donor cells while the physiological state of recipient cells did not seem to impact plasmid transfer (Muela et al., 1994, Arana et al., 1997, Sudarshana and Knudsen, 1995). In contrast to our results, Smets et al. (1993) showed that plasmid transfer rates were the highest with $P$. putida 
(TOL) donor cultures harvested from the exponential phase, and lower rates were obtained with stationary phase donor cultures. Frost and Manchak (1998) investigated whether the F transfer apparatus breaks down at the stationary phase in Escherichia coli strains and their results showed that the plasmid transfer frequency decreased at the mid exponential phase while proteins involved in transfer functions, such as TraA (pilin synthesis), TraD (DNA transport), TraT (surface exclusion) remained constant in the stationary phase. Under normal physiological conditions, production of $\mathrm{F}$ pili by the donor is needed for the mating pair formation and the maximum piliation is attained at the end of the exponential growth phase (Novotny and Lavin, 1971).

Seoane et al. (2011) reported that plasmid conjugation is more likely to occur through the lateral cell walls rather than through the cell pole regions, and showed that the number of plasmid transfer events increased with recipient cell elongation. The microscopic images from Babic et al. (2008) also supported conjugation occurred through the lateral walls when they visualized the conjugation mechanism in Escherichia coli by using fluorescent protein SeqA-YFP. According to Bauer et al. (2011) in gram positive Bacillus subtilis plasmid pLS20 was found at the cell pole indicating that transfer occurred at the pole. VirD2 (relaxes) and VirD4 (coupling protein) were also located at the cell pole. The authors concluded "pole is the preferred site for assembly of active conjugation apparatus".

According to Gilbert et al. (2016) among 205 R27 genes, 33\% showed growth phase-dependent expression. A total of 42 genes had higher expression in the exponential phase, whereas 26 genes were expressed more in the early stationary phase. Among the genes with altered expression, 21 belonged to the tra operon (tra genes). In their study, increased conjugation frequency detected in exponentially growing cells, 18 of the $21 \mathrm{tra}$ genes were induced in actively growing cells, 
including those encoding crucial proteins for conjugation. They also detected the expression of tra genes $\operatorname{traH}, \operatorname{trh} R, \operatorname{trh} F$ in the exponential phase but not in the early stationary phase (except for $\operatorname{trhR})$.

In our study, we monitored expression of traA, a gene which encodes the $13-\mathrm{kDa}$ precursor protein needed for pilin subunit synthesis (Maneewannakul et al., 1993). The results showed that $\operatorname{traA}$ expression was detected by RT-PCR in samples collected from early and late exponential phases, but not in samples collected from the late stationary phase (Fig. 4.12). This was surprising, as we anticipated that a higher transconjugant percentage will correspond to increased expression of traA. Since the highest percentage of transconjugants was detected in the stationary phase (when expression of $\operatorname{tra} A$ was not detected), but expression of $\operatorname{tra} A$ was pronounced during early exponential phase, we concluded that expression of traA in donor cells does not coincide with enhanced transconjugant abundance. It is possible that once pilin subunits are synthesized, they may persist into the stationary phase where they mediate conjugation. Further investigation can be performed using proteomics or western blotting to characterize proteins that may be involved in conjugation in cells grown to stationary phase.

Similarly to our results, Frost and Manchak (1998) showed that the traA transcript decreased to below detectable levels approximately 2 hours after the mid-exponential phase of an $E$. coli strain, while the levels of TraA persisted at constant levels in the stationary phase. We speculate that factors (e.g. distance between the cells, cell position) other than traA expression associated with donor and recipient cell growth phases affect plasmid transfer and transconjugant formation. 


\subsubsection{Effect of plasmid donor growth phases on plasmid transfer in biofilms}

The quantitative data obtained from microscopic images revealed that transconjugants expressed as the percentage of all cells were $0.11 \pm 0.1 \%$ and $0.20 \pm 0.2 \%$ when donor cells grown to early exponential growth phase and late stationary growth phase were added to $24 \mathrm{~h}$ old recipient biofilm, respectively. These results were not significantly different. The results did not support our hypothesis as no significant difference in transconjugant formation was obtained when donor cells grown to early exponential phase or late stationary phase were added to $24 \mathrm{~h}$ old recipient biofilms.

We chose to use $24 \mathrm{~h}$ old biofilms because $24 \mathrm{~h}$ old biofilms presented a confluent layer of cells; earlier experiments performed in our lab showed that older biofilms were thicker (> $60 \mu \mathrm{m})$, possessed a greater abundance of EPS and hindered plasmid transfer (data not shown). Presence of EPS may inhibit conjugative pilus reach between plasmid donor and potential recipient cells in biofilms (Merkey et al., 2011). Seoane et al. (2011) identified parameters (e.g. conjugation rate, donor-recipient distance and positioning) that may control bacterial conjugation in biofilms at the individual cell level while investigating the inability of the pWWO TOL plasmid to invade P. putida microcolonies and biofilms. Their results showed that pWWO transfer occurs not only between cells in direct cell to cell contact, but also between two distant cells since plasmid transfer took place when donor-recipient cells were separated by a distance of 5-10 $\mu \mathrm{m}$. Their results also revealed that conjugation occurs more frequently through the lateral wall of the donor cells than through the poles as they obtained highest number of successful mating pairs when plasmid donor and recipient cells attached with lateral wall. They suggested that plasmid transfer within biofilms is limited due to spatial constraints which exist within organized 
microbial communities such as biofilms. Similarly, cell positioning, distance between plasmid donor and recipient cells may have influenced the outcome of our experiments.

In summary, this project discussed the effect of cell growth phases on transconjugant formation in plate matings on agar plates using planktonically grown cultures and in $24 \mathrm{~h}$ old recipient biofilms grown on microscopic slides. Our results showed that in plate matings, the highest percentage of transconjugants was obtained when both plasmid donor and recipient cells were harvested from the stationary phase, when the cell size of both the donor and recipient cells was the smallest. The lowest percentage of transconjugants was obtained when donor cells were grown to exponential growth phase and recipient cells were grown to stationary growth phase. In biofilms, the percentage of transconjugants was not significantly different whether the donor was harvested from the early exponential or the late stationary phase and added to $24 \mathrm{~h}$ old recipient biofilms. These results show that the growth phase of the plasmid donor did not influence plasmid transfer frequency in biofilms, and while no clear trends exist for the plate mating experiments, the findings indicate that when either the donor or the recipient or both were harvested from the exponential phase, transconjugant formation was significantly lower than when both the donor and recipient were harvested from the stationary phase.

\subsection{Optimization of RT-PCR to detect expression of $\operatorname{traA}$ in plasmid donor cells}

To optimize the RT-PCR method, RNA was extracted from different growth phases of donor cells by using FastPrep system and cDNA was synthesized. Also gradient PCR was performed to optimize the annealing temperature. For gradient PCR colony cells or DNA was used as template. Our results showed that when donor DNA was used as template (Figure 4.23) at 55.3 $\mathrm{C}$ annealing temperature, a bright band was observed and there was no presence of primer 
dimers. Based on these gradient PCR results, $55.3^{\circ} \mathrm{C}$ was used as the annealing temperature for traA primers.

To optimize RT-PCR for the detection of $\operatorname{traA}$ expression, it was necessary to determine the optimal primer annealing temperature. To confirm that cDNA was synthesized and RNA samples were free from genomic DNA, a negative control (no reverse transcriptase enzyme added during the cDNA synthesis from RNA) was included for all samples. Replicates were included for each sample. Also, to prevent the degradation of RNA; nuclease free water, pipette tips were used for RNA extraction and cDNA synthesis. By using the annealing temperature of $55.3^{\circ} \mathrm{C}$, the presence of $t r a A$ was detected by RT-PCR in $P$. putida BBC443 cells grown to early exponential phase $(6.5 \mathrm{~h})$ and late exponential phase $48 \mathrm{~h}$ (chapter 4 , section 4.1.1).

\subsection{Effect of nutrient concentrations on the determination of minimum inhibitory concentration of antibiotics}

For kanamycin, gentamicin, rifampicin and tetracycline the minimum inhibitory concentrations decreased as nutrient concentration (\% LB) decreased (Table 4.3). The minimum bactericidal concentration of gentamicin also decreased for $P$. putida BBC443 with decreased nutrient concentration (Figure A1). Kanamycin and gentamicin are aminoglycoside antibiotics, which bind to the $30 \mathrm{~S}$ subunit of bacterial ribosome and inhibit protein synthesis (Jana and Deb, 2006, Mingeot-Leclercq et al., 1999). Tetracycline antibiotics inhibit bacterial protein synthesis by preventing the association of aminoacyl tRNA with the bacterial ribosome (Chopra and Roberts, 2001). Rifampicin inhibits RNA polymerase, this enzyme is involved in transcription of DNA to RNA (Wehrli, 1983). Greulich et al. (2015) investigated the effect of ribosome binding antibiotics (streptomycin, kanamycin, tetracycline and chloramphenicol) on Escherichia coli. 
Their results revealed that for some of the antibiotics faster growth increases susceptibility to the antibiotics. For irreversibly binding antibiotics (streptomycin and kanamycin), faster growing cells are less susceptible to antibiotics. For reversibly binding antibiotics (tetracycline and chloramphenicol), faster growing cells are more susceptible to antibiotics. The authors mentioned that in the presence of high nutrients, fast growing cells have a larger ribosome pool and higher ribosome synthesis rate, so that they are able to tolerate a higher rate of antibiotic than slow-growing cells. In our study, for all ribosome binding antibiotics (kanamycin, gentamicin and tetracycline) susceptibility increased with lower nutrient concentrations. We tested the effect of cell numbers, presence of extracellular DNA and biomass on MIC of gentamicin to determine if these have protective effect and increase the MIC. We also measured the $\mathrm{pH}$ when different cell numbers were added as inoculum, because aminoglycoside antibiotics are less effective in lower pH (Jana and Deb, 2006). We tested the effect of cell numbers as with the higher nutrients cells grow to greater cell densities than at lower nutrient environments. One of our objectives was to test if MIC increases with higher cell number.

Our results showed that with the different cell numbers e.g. $10^{3}, 10^{5}, 10^{7} \mathrm{CFU} / \mathrm{mL}$ as inoculum MIC of gentamicin decreased with the lower nutrient concentrations (Table 4.4). MICs of gentamicin for different nutrient concentrations $\left(100,50\right.$ and 10\%) were higher when $10^{7}$ $\mathrm{CFU} / \mathrm{mL}$ was added as the inoculum than when $10^{3}$ or $10^{5} \mathrm{CFU} / \mathrm{mL}$ was used as inocula. The increase in the number of bacterial cells $\left(10^{7} \mathrm{CFU} / \mathrm{mL}\right)$ led to an increase of the minimum inhibition concentration of gentamicin; more antibiotic was required to inhibit the growth of $P$. putida cells.

We tested the effect of extracellular DNA and biomass on MIC of gentamicin if these provide protective effect from gentamicin in the planktonic cells. Extracellular DNA can increase MICs 
due to the binding of anionic DNA with positively charged aminoglycosides (Chiang et al., 2013, Drew et al., 2009). Our results showed that when 5 or $10 \mu \mathrm{g} / \mathrm{mL}$ extracellular DNA and $10^{5}$ $\mathrm{CFU} / \mathrm{mL}$ were added together with cells at the beginning of the MIC assay, growth was observed at MIC and higher MIC of gentamicin (Table 4.7). However, when $10^{3} \mathrm{CFU} / \mathrm{mL}$ was added as inoculum no growth was observed in the presence of extracellular DNA at higher MIC of gentamicin, suggesting that the concentrations of DNA used in our study did not provide a protective effect with lower cell numbers as inocula. Similar results were obtained when heat inactivated biomass $\left(10^{7} \mathrm{CFU} / \mathrm{mL}\right.$ dead cells $)$ was added. Heat inactivated biomass was added to test if it provides protective effect from gentamicin, since the positively charged gentamicin molecules could bind to the negatively charged cellular components resulting in a reduction of available antibiotic. For $10^{5} \mathrm{CFU} / \mathrm{mL}$ (as inoculum) growth was observed at MIC and higher MIC of gentamicin; growth was not observed for $10^{3} \mathrm{CFU} / \mathrm{mL}$ as inoculum (Table 4.8). As the aminoglycosides are polycationic molecules, our results suggest that DNA and biomass may provide protective effect when combined with high enough cell numbers (as inocula), possible through binding of gentamicin by the negatively charged DNA and cellular components. Uptake of the gentamicin by bacteria depends on surrounding $\mathrm{pH}$ (Eisenberg et al., 1984, Henry Stanley et al., 2014, Baudoux et al., 2007). According to Baudoux et al. (2007), acidic pH reduced the activity of gentamicin in Staphylococcus aureus as the MIC was 70 times higher at $\mathrm{pH} 5.0$ than at $\mathrm{pH}$ 7.4. For our experiments, $\mathrm{pH}$ was measured before and after the incubation.

Before incubation the $\mathrm{pH}$ of the medium was 6.8. After $18 \mathrm{~h}$ of incubation, the $\mathrm{pH}$ at MIC (no visible growth was observed) of gentamicin remained at 6.8-6.9. At a gentamicin concentration lower than MIC (0.5× MIC), growth was observed and the end-of incubation $\mathrm{pH}$ was 7.1-7.7 (Table 4.5 and Table 4.6), however, we do not consider this increase in $\mathrm{pH}$ to be significant. For 
decreased nutrient concentration (100\%, 50\% and 10\% LB), MIC also decreased in our experiments and it was not dependent on $\mathrm{pH}$ as the $\mathrm{pH}$ change during incubation was insignificant.

According to Henry Stanley (2014) Staphylococcus aureus biofilms grown with $3 \times$ TSB (supplemented with glucose) had increased resistance to gentamicin and streptomycin than biofilms grown with $1 / 3 \times$ and $1 \times$ TSB (supplemented with glucose or without glucose). The authors confirmed that for $3 \times$ TSB (supplemented with glucose) $\mathrm{pH}$ was 4.85-5.10. The acidic condition helped to decrease the inhibitory effect of gentamicin at higher nutrient concentration. Hancock et al. (1981) found in both Escherichia coli and P. aeruginosa aminoglycoside uptake occurs in three steps, (1) initial electrostatic binding, (2) slow uptake phase, (3) rapid uptake phase. The initial binding is energy independent, whereas the last two steps are energy dependent and require active electron transport system. Our results showed that inhibition of $P$. putida BBC443 by gentamicin is nutrient dependent as the MICs decreased with lower nutrient concentration. $P$. putida $\mathrm{BBC} 443$ is more susceptible to gentamicin at lower nutrient concentrations. Our results also showed that as for gentamicin, the MICs for kanamycin, rifampicin and tetracycline decreased with decreased nutrient concentrations for P. putida strains. These results supported our hypothesis. Our hypothesis was the values of minimum inhibitory concentration of antibiotics will decrease with decreasing nutrient concentrations.

For $P$. putida BBC443, MICs of gentamicin at different nutrient concentration increased with the increased cell numbers. After incubation, $\mathrm{pH}$ did not change drastically at MIC or lower than MIC of gentamicin for $P$. putida $\mathrm{BBC} 443$ and thus did not have a role in the decrease of MICs of gentamicin with lower nutrient concentration. We also conclude that heat inactivated biomass and extracellular DNA might have protective effect from gentamicin as visible growth was 
observed at MIC and higher than MIC when $10^{5} \mathrm{CFU} / \mathrm{mL}$ was added as inoculum. Further investigation should be directed to study the effect of antibiotics in biofilms with varying nutrient concentration.

\subsection{The effects of subinhibitory and minimum inhibitory concentrations of gentamicin on transconjugant formation in biofilms and plate matings}

In plate mating experiments, using planktonically grown cultures, transconjugant formation was higher when the donor cells were grown with $0.5 \times$ MIC of gentamicin and additionally challenged with MIC of gentamicin for $1 \mathrm{~h}$ and no antibiotic was added in the LB plate (Table 4.9). This result was significantly different from when donor cells were not exposed to gentamicin and no gentamicin was added to the LB plate (transconjugants comprised $2.5 \pm 1.20$ $\%$ of total cells) (Table 4.9, Figure 4.24). These results supported our hypothesis. Our hypothesis was the number of transconjugants will be greater following gentamicin exposure.

The transconjugant formation was similar when the plate mating was done in the presence of $0.5 \times$ MIC of gentamicin and plasmid donor cells were additionally challenged with MIC for $1 \mathrm{~h}$, mating plate contained MIC of gentamicin (percentages of transconjugants in the total cells were $3.5 \pm 0.99$ and $3.7 \pm 1.57$, respectively) (Table 4.9).

A study done by Zhang et al. (2013) showed that the conjugative transfer of plasmids pRK2013, pSU2007 and RP4 was enhanced between Escherichia coli strains in the presence of combination of MIC of kanamycin and streptomycin (MICs were added to the plates). Their study demonstrated that in the presence of kanamycin and streptomycin 60 proteins were downregulated and 14 proteins were upregulated in the conjugation of E. coli strains after $12 \mathrm{~h}$ mating incubation. Two proteins, oligopeptide-binding protein (OppA) and ribose-binding 
protein $(\mathrm{RbsB})$ were involved in the enhanced conjugation of $E$. coli in the presence of kanamycin and streptomycin. Conjugative transfer of the plasmid was also greatly increased by the presence of low doses of both antibiotics in the mating medium (Xia et al., 2008).

It has been reported in a few studies that in the presence of subinhibitory concentration of antibiotics gene transfer can be enhanced. Sublethal concentration of a DNA binding agent, mitomycin C induced SOS response and stimulated gene transfer. SXT, a conjugative element encoding resistance to chloramphenicol, sulphamethoxazole, trimethoprim and streptomycin in Vibrio cholerae was transferred and integrated at a much higher efficiency when the donor was exposed to subinhibitory concentration of mitomycin C (Beaber et al., 2003).

According to Salcedo et al. (2015), $100 \mathrm{ppb}$ and 1,000 ppb of tetracycline exposure induced biofilm formation in Escherichia coli which contained plasmid pB10. Tetracycline resistance was encoded on the plasmid pB10. But in Pseudomonas aeruginosa which lacked plasmid pB10, biofilm formation was not induced in the presence of tetracycline. Their results also showed that in the mixed culture of E. coli and P. aeruginosa, transconjugant formation varied with different concentrations of antibiotics. The highest numbers of transconjugants were obtained in the presence of 100 and $1000 \mathrm{ppb}$ of cephradine, streptomycin, gentamicin, and tetracycline. For ciprofloxacin and amoxicillin, the highest numbers of transconjugants were obtained in the presence of 1 and 10,000 ppb concentrations of antibiotics. The authors concluded that with the exposure to different antibiotics, transcription pattern varies as antibiotics act as signaling molecules. Subinhibitory concentration of a $\beta$ lactam antibiotic, penicillin also stimulated plasmid transfer in Staphylococcus aureus (Barr et al., 1986).

Scornec et al. (2017) also found that subinhibitory concentration of some ribosome-targeting antibiotics (e.g. tetracycline) can induce the transfer of conjugative transposon Tn916 in 
Enterococcus faecalis. The authors tested the ability of different classes of antibiotics to modulate the activity of promoter $\mathrm{P}_{\text {orf12 }}$ controlling the transfer of Tn916 by developing a promoter- reporter (pSHlux:: $\mathrm{P}_{\text {orf } 12}$ ) fusion method. Their results showed that inducibility of $\mathrm{P}_{\text {orf } 12 \mathrm{~W}}$ as two to three folds higher in the presence of spectinomycin, tetracycline, doxycycline, lincomycin and clindamycin antibiotics. These five antibiotics stimulated the transfer of Tn916 with maximum transfer frequency. Maximum transfer frequency was obtained due the maximum induction of $\mathrm{P}_{\text {orf12. }}$

The subinhibitory concentration of a biocide can also enhance gene transfer. Seier-Petersen et al. (2013) reported that subinhibitory concentration of ethanol enhanced transposon Tn916 in Bacillus subtilis. The transcriptional response of tet(M) (involved in recombination and conjugation of the element) to the biocides started at $2 \mathrm{~h}$ after exposure for ethanol, $1.5 \mathrm{~h}$ for hydrogen peroxide, $0.5 \mathrm{~h}$ for chlorhexidine digluconate and $1.5 \mathrm{~h}$ for sodium hypochlorite. Subinhibitory concentrations of antibiotics (e.g. fluoroquinolones, $\beta$-lactams and aminoglycosides) have been shown to induce the SOS response and the RpoS induction. Induction of the SOS response by sublethal antibiotic concentrations was also shown to increase the rate of horizontal gene transfer by prophage induction, integrative conjugative elements and transposition (Andersson and Hughes, 2014).

In our study, in plate matings a higher abundance of transconjugants expressed as the percentage of transconjugant in total cells $(4.3 \pm 0.62 \%)$ was detected when the donor cells were exposed to $0.5 \times$ MIC of gentamicin, additionally challenged with MIC of gentamicin for $1 \mathrm{~h}$ and no gentamicin was added to the plates (Table 4.9). Our experiments with plasmid transfer in biofilms did not show an increase in transconjugant formation when either donor cells were grown with $0.5 \times$ MIC gentamicin or when additionally $0.5 \times$ MIC gentamicin was added to the 
biofilms. The presence of $0.5 \times$ gentamicin in the donor/recipient wells was associated with a lower transconjugant abundance in comparison to the control (no gentamicin addition in the biofilms). Preliminary results indicate that an additional challenge of the donor strain at MIC and addition of gentamicin at MIC to recipient biofilms (following the addition of donor cells) enhanced transconjugant formation in biofilms. Additional studies should be performed to determine if exposure to antibiotics at MIC changes expression of genes relevant for conjugation. 


\section{Chapter 6}

\subsection{Conclusions}

Subinhibitory concentrations of antibiotics are environmentally relevant due to their extensive human and veterinary applications. Antibiotic resistance is one the most serious problems for public health. The spread of antibiotic resistance in microbes by horizontal gene transfer is a serious hindrance to therapeutic effectiveness. To study the effect of subinhibitory concentrations of antibiotics on transconjugant formation in both planktonic cultures and biofilms will shed light on their effect on the spread of antibiotic resistance in environments.

One of the objectives of this research project was to study the effect of cell growth phases (exponential and stationary) of plasmid donor and recipient cells on transconjugant formation in planktonic cell batch cultures and to study the effect of growth phases of plasmid donor cells on transconjugant formation in biofilms. This may explain the importance of cell growth activity for plasmid spread. Our results showed that in plate mating experiments, the highest percentage of transconjugants was obtained when both plasmid donor and recipient cells were harvested from the late stationary phase. The lowest percentage of transconjugants was obtained when donor cells were grown to exponential growth phase and recipient cells were grown to stationary growth phase.

In biofilms, the percentage of transconjugants was not significantly different whether the donor was harvested from the early exponential or the late stationary phase and added to $24 \mathrm{~h}$ old recipient biofilms. These results showed that the growth phase of the plasmid donor did not influence plasmid transfer frequency in biofilms. 
Expression of $\operatorname{traA}$ (involved in pilus biosynthesis) was detected from the plasmid donor cells grown to early exponential and late exponential phase by performing RT-PCR, indicating that $\operatorname{traA}$ expression did not coincide with greater transconjugant abundance.

Another objective of this project was to determine the minimum inhibitory concentration (MIC) of four antibiotics (kanamycin, gentamicin, rifampicin, and tetracycline) at 100\%, 50\%, and $10 \%$ LB broth for Pseudomonas putida strains. Our results showed that with decreased amount of nutrient concentration, MIC also decreased for both strains. Heat inactivated biomass and extracellular DNA may have a protective effect from gentamicin as visible growth was observed at MIC and above MIC of gentamicin when $10^{5} \mathrm{CFU} / \mathrm{mL}$ was added as inoculum. Future studies will be performed to determine the effect of varying nutrient concentration on antibiotics in $P$. putida biofilms.

Another objective was to study the effect of subinhibitory concentration and minimum inhibitory concentration of gentamicin on transconjugant formation in planktonic cell batch cultures and in biofilms. In plate mating experiments, a higher abundance of transconjugants expressed as a percentage of total cells was detected when the donor cells were exposed to $0.5 \times$ MIC gentamicin, additionally challenged with gentamicin at MIC for $1 \mathrm{~h}$ and no gentamicin was added to the plate on which plate matings were carried out. Preliminary results indicate that an additional challenge of the donor strain at MIC and addition of gentamicin at MIC to recipient biofilms (following the addition of donor cells) enhance transconjugant formation in biofilms. More controlled studies, together with RNA sequencing, should be performed to determine how exposure to antibiotics at MIC changes gene expression in donor cells and recipient biofilms. 


\subsection{Recommendations}

For future work, transconjugant formation frequency can be studied in the presence of kanamycin, rifampicin, and tetracycline. For kanamycin, resistance is encoded on the plasmid pWWO, resistance for rifampicin is encoded on the donor chromosome. Further studies to investigate the effect of kanamycin and rifampicin on transconjugant formation will provide information if transconjugant formation frequency will be enhanced in the presence of these antibiotics due to the encoded resistance. Tetracycline is commonly found in the environment. The donor and recipient (used in this research project) strains do not carry resistance against tetracycline. Yet its mode of action is similar to that of kanamycin and gentamicin (inhibition of protein synthesis). Thus investigating the effect of tetracycline on plasmid transfer would allow us to draw conclusions about the effect of antibiotics with a similar mode of action but with different susceptibility profiles in donor and recipient cells. Also, it would be important to determine if plasmid transfer frequency differs in single species recipient as opposed to mixed recipient community exposed to antibiotics as in the environment microorganisms are found in mixed communities.

RNA sequencing can be used to perform differential gene expression analysis in the presence of subinhibitory and minimum inhibitory concentration of antibiotics. RNA sequencing will provide data about expression of other genes involved in plasmid transfer in plasmid donor and recipient cells. RNA sequencing can also provide information if genes (for example, metal resistance and antibiotic resistance genes) may be co-regulated upon exposure to antibiotics.

Microarrays can also be used to measure the expression level of known genes in the presence or absence of antibiotics. 


\section{Appendices}

Appendix A: Effect of nutrient concentrations on minimum inhibitory concentration of antibiotics.

Table A1. Minimum bactericidal concentration (MBC) of gentamicin for P putida BBC443 with varying nutrient concentrations, $10^{5} \mathrm{CFU} / \mathrm{mL}$ was added as inoculum.

\begin{tabular}{|l|l|}
\hline Nutrient concentrations (LB) & Minimum bactericidal concentrations $(\mu \mathrm{g} / \mathrm{mL})$ \\
\hline $100 \%$ & Between $30-40$ \\
\hline $50 \%$ & Between $5-10$ \\
\hline $10 \%$ & Between $5-10$ \\
\hline
\end{tabular}

Table A2. Determination of minimum bactericidal concentrations (MBC) for P. putida BBC443 and $P$. putida ATCC12633 with $100 \%$ LB.

\begin{tabular}{|c|c|c|}
\hline Antibiotics & Strains & $\begin{array}{l}\text { Minimum bactericidal } \\
\text { concentration }(\mu \mathrm{g} / \mathrm{mL})\end{array}$ \\
\hline \multirow[t]{2}{*}{ Kanamycin } & P. putida $\mathrm{BBC} 443$ & $>400$ \\
\hline & P. putida ATCC12633 & $>100$ \\
\hline \multirow[t]{2}{*}{ Gentamicin } & P. putida $\mathrm{BBC} 443$ & Between 30-40 \\
\hline & P. putida ATCC12633 & $>70$ \\
\hline \multirow[t]{2}{*}{ Rifampicin } & P. putida $\mathrm{BBC} 443$ & $>160$ \\
\hline & $P$. putida ATCC12633 & $>80$ \\
\hline \multirow[t]{2}{*}{ Tetracycline } & P. putida $\mathrm{BBC} 443$ & $>60$ \\
\hline & P. putida ATCC12633 & $>70$ \\
\hline
\end{tabular}

Table A3. Determination of minimum biofilm eradication concentration (MBEC) of P. putida ATCC12633 with $100 \%$ LB.

\begin{tabular}{|l|l|}
\hline Antibiotics & Minimum biofilm eradication concentration \\
\hline Kanamycin & Between $900-1000 \mu \mathrm{g} / \mathrm{mL}$ \\
\hline Gentamicin & $<900 \mu \mathrm{g} / \mathrm{mL}$ \\
\hline Rifampicin & $>10,000 \mu \mathrm{g} / \mathrm{mL}$ \\
\hline Tetracycline & Between $2000-2500 \mu \mathrm{g} / \mathrm{mL}$ \\
\hline
\end{tabular}




\section{References}

Achtman M., Kennedy N., and Skurray R. 1977. Cell-cell interactions in conjugating Escherichia coli: role of traT protein in surface exclusion. Proc. Natl. Acad. Sci. USA. 74, 51045108.

Andersson D. I. and Hughes D. 2014. Microbiological effects of sublethal levels of antibiotics. Nat. Rev. Microbiol. 12 (7), 465-478.

Andews J. M. 2001. Determination of minimum inhibitory concentrations. J. Antimicrob. Chemother. 48, 5-16.

Anthony K. G., Klimke W. A., Manchak J., and Frost L. S. 1999. Comparison of proteins involved in pilus synthesis and mating pair stabilization from the related plasmids F and R100-1: Insights into the mechanism of conjugation. J. Bacteriol. 181(17), 5149-5159.

Anzai Y., Kim H., Park J.Y., Wakabayashi H., and Oyaizu H. 2000. Phylogenetic affiliation of the Pseudomonads based on 16S rRNA sequence. Inter. J. of Sys and Evo. Microbiol. 50, 15631589.

Arana J. I., Justo A., Muela A., Pocino M., Iriberri J., and Barcina I. 1997. Influence of a survival process in a freshwater system upon plasmid transfer between Escherichia coli strains. Microb. Ecol. 33, 41-49.

Arutyunov D. and Frost L. S. 2013. F conjugation: Back to the beginning. Plasmid. 70, 18-32.

Ashby M. J., Neale J. E., Knott S. J., and Critchley I. A. 1994. Effect of antibiotics on nongrowing planktonic cells and biofilms of Escherichia coli. J. Antimicrob. Chemother. 33, 443152. 
Ashby M. J., Neale J. E., Knott S. J., and Critchley I. A. 1994. Effect of antibiotics on nongrowing planktonic cells and biofilms of Escherichia coli. J. Antimicrob. Chemother. 33, 443-52. Azucena E. and Mobashery S. 2001. Aminoglycoside-modifying enzymes: mechanisms of catalytic processes and inhibition, Drug resistance updates. 4, 106-17.

Auerbach E.A., Seyfried E. E., and McMahon K. D. 2006. Tetracycline resistance genes in activated sludge waste water treatment plants. Water Environment Foundation, 1478-1493.

Babić A., Lindner A. B., Vulić M., Stewart E. J., and Radman M. 2008. Direct visualization of horizontal gene transfer. Science. 319. 1533-1535.

Bagge N., Schuster M., Hentzer M., Ciofu O., Givskov M., Greenberg E.P., and Hoiby N. 2004. Pseudomonas aeruginosa biofilms exposed to imipenem exhibit changes in global gene expression and b-Lactamase and alginate production. Antimicrob. agents Chemother. 48(4), 1175-1187.

Baharoglu Z. and Mazel D. 2011. Vibrio cholerae triggers SOS and mutagenesis in response to a wide range of antibiotics: a route towards multiresistance. Antimicrob. Agents Chemother. 55 (5), 2438-2441.

Barr V., Barr K., Millar M. R., and Lacey R. W. 1986. $\beta$-lactam antibiotics increase the frequency of plasmid transfer in Staphylococcus aureus. J. Antimicrob. Chemother. 17, 409-413.

Bathe S., Mohan T.V.K., Wuertz S., and Hausner M. 2004. Bioaugmentation of a sequencing batch biofilm reactor by horizontal gene transfer. Wat. Sci. Tech. 49, 337-344.

Bathe S., Schwarzenbeck N., and Hausner M. 2005. Plasmid-mediated bioaugmentation of activated sludge bacteria in a sequencing batch moving bed reactor using pNB2. Lett. Appl. Microbiol. 41, 242-247. 
Bathe S., Schwarzenbeck N., and Hausner M. 2009. Bioaugmentation of activated sludge 3chloroaniline removal with a mixed population carrying a degradative plasmid. Bioresour. Technol. 100, 2902-2909.

Baudoux P., Bles N., Lemaire S., Mingeot-Leclercq M.P., Tulkens P. M., and Bambeke F. V. 2007. Combined effect of $\mathrm{pH}$ and concentration on the activities of gentamicin and oxacillin against Staphylococcus aureus in pharmacodynamic models of extracellular and intracellular infections. J. Antimicrob. Chemother. 59, 246-253.

Beaber J. W., Hochhut B., and Waldor M. K. 2003. SOS response promotes horizontal dissemination of antibiotic resistance genes. Nature. 427, 72-74.

Bester E., Wolfaardt G., Joubert L., Garny K., and Saftic S. 2005. Planktonic-Cell Yield of a Pseudomonad Biofilm. Appl. Environ. Microbiol. 71(12), 7792-7798.

Bruchmann J., Kirchen S., and Schwartz T. 2013. Sub-inhibitory concentrations of antibiotics and wastewater influencing biofilm formation and gene expression of multi-resistant Pseudomonas aeruginosa wastewater isolates. Environ. Sci. Pollut Re. 20, 3539-49.

Bustin S. A., Benes V., Garson J. A., Hellemans J., Huggett J., and Kubista M., et al. 2009. The MIQE Guidelines: Minimum Information for Publication of Quantitative Real-Time PCR Experiments. Clinical Chemistry. 55(4), 611-622.

Chakrabarty A. M. 1976. Plasmids in Pseudomonas. Ann. Rev. Genet. 10, 7-30.

Chiang W. N., Nilsson M., Jensen P. O., Hoiby N, Neilsen T. E., Givscov M., and TolkerNeilsen T., 2013. Extracellular DNA shields against Aminoglycosides in Pseudomonas aeruginosa biofilms. Antimicrob. Agents Chemother. 57 (5), 2352-2361. 
Christensen B. B., Sternberg C., Andersen J. B., Eberl L., Moller S., Givskov M., and Molin S. (1998). Establishment of new genetic traits in a microbial biofilm community. Appl. Environ. Microb. 64 (6), 2247-2255.

Christensen B.B., Sternberg C., Andersen J. B., Eberl L., Moller S., Givskov M., and Molin S. 1998. Establishment of new genetic traits in a microbial biofilm community. Appl. Environ. Microbiol. 64 (6), 2247-2255.

Chopra I. and Roberts M. 2001. Tetracycline antibiotics: mode of action, applications, molecular biology, and epidemiology of bacterial resistance. Microbiol. Mol. Biol. Rev. 65 (2). 232-260.

Ciofu O. and Tolker-Nielsen T. 2011. Antibiotic tolerance and resistance in biofilms. Biofilm Infections, 215-229.

Collet A., Cosette P., Beloin C., Ghigo, J.M., Rihouey C., Lerouge P., Junter G. A., and Jouenne T. 2008. Impact of rpoS deletion on the proteome of Escherichia coli grown planktonically and as biofilm. J. Proteome Res. 7, 4659-4669.

Cook L., Chatterjee A., Barnes A., Yarwood J., Hu W-S., and Dunny G. 2011. Biofilm growth alters regulation of conjugation by a bacterial pheromone. Mol. Microbiol. 81, 1499-1510.

Cram D. S., Loh S. M., Cheah K. C., and Skurray R. A. 1991. Sequence and conservation of genes at the distal end of the transfer region on plasmids F and R6-5. Gene. 104, 85-90.

D’Alvise P. W., Sjøholm O. R., Yankelevich T., Jin Y., Wuertz S., and Smets B. F. 2010. TOL plasmid carriage enhances biofilm formation and increases extracellular DNA content in Pseudomonas putida KT2440. FEMS Microbiol. Lett. 3, 1284-1292.

Davies D. 2003. Understanding biofilm resistance to antibacterial agents. Nat. Rev. Drug Discov. $2,114-22$. 
Davies J., Spiegelman G. B., and Yim G. 2006. The world of subinhibitory antibiotic concentrations. Curr. Opin. Microbiol. 9, 445-453.

Devarajan N, Kohler T., Sivalingam P., Delden C., Mulaji C. K., Mpiana P. T., Ibelings B. W., and Pot J. 2017. Antibiotic resistant Pseudomonas spp. in the aquatic environment: A prevalence study under tropical and temperate climate conditions. Water Research. 115, 256-265.

Di Laurenzio L., Frost L. S., and Paranchych W. 1992. The TraM protein of the conjugative plasmid F binds to the origin of transfer of the F and ColE1 plasmids. Mol. Microbiol. 6, 29512959.

Dowding J. E. 1976. Mechanisms of gentamicin resistance in Staphylococcus aureus. Antimicrob Agents Chemother. 11 (1), 47-50.

Drew K. R. P., Sanders L. K. Culumber Z. W. Zribi O., and Wong G. C. L. 2009. Cationic amphiphiles increase activity of aminoglycoside antibiotic tobramycin in the presence of airway polyelectrolytes. J. Am. Chem. Soc. 131, 486-493.

Eisenberg E. S., Mandel L. J., and Kaback H. R. et al. 1984. Quantitative association between electrical potential across the cytoplasmic membrane and early gentamicin uptake and killing in Staphylococcus aureus. J. Bacteriol. 15, 863-867.

Farouk F., Azzazy H. M. E., and Niessen W. M. A. 2015. Challenges in the determination of aminoglycoside antibiotics, a review. Analytica Chimica Acta. 890, 21-43.

Finkel S. E. 2006. Long-term survival during stationary phase: evolution and the GASP phenotype. Nat. Rev. Microbiol. 4, 113-120. 
Firth N., Ippen-Ihler K., and Skurray R. 1996. Structure and function of the F factor and mechanism of conjugation. In Neidhardt F. et al. (eds), Escherichia coli and Salmonella: Cellular and Molecular Biology, second edition, ASM Press, Washington, D.C, p. 2377-2401.

Fowler T., Taylor L., and Thompson R. 1983. The control region of the F plasmid transfer. operon: DNA sequence of the traJ and traY genes and characterisation of the traY-Z promoter. Gene. 26, 79-89.

Fox R. E., Zhong X., Krone S. M., and Top E. M. 2008. Spatial structure and nutrients promote invasion of IncP-1 plasmids in bacterial populations. ISME J. 2, 1024-1039.

Frost L. S. and Koraimann G. 2010. Regulation of bacterial conjugation: balancing opportunity with adversity. Future Microbiol. 5, 1057.

Frost L. S., Leplae R., Summers A. O., and Toussaint A. 2005. Mobile genetic elements: The agents of open source evolution, Nature Rev. 3, 722-732.

Frost L. S. and Manchak J. 1998. F-phenocopies: characterization of expression of the F transfer region in stationary phase. Microbiology.144, 2579-2587.

Frost L.S., Ippen-Ihler K., and Skurray R. A. 1994. Analysis of the sequence and gene products of the transfer region of the F sex factor. Microbiol. Rev. 58, 162-210.

Frost L. S., Paranchych W., and Willetts N. S. 1984. DNA sequence of the F traALE region that includes the gene for F pilin. J. Bacteriol. 160, 395-401.

Gefen O., Fridman O., Ronin I., and Balaban N. Q. 2014. Direct observation of single stationaryphase bacteria reveals a surprisingly long period of constant protein production activity. PNAS. 111, 556-561. 
Ghigo J. M. 2001. Natural conjugative plasmids induce bacterial biofilm development. Nature. 412, 442-445.

Gibert M., Juárez A., Zechner E. L., Madrid C., and Balsalobre C. 2014. TrhR, TrhY and HtdA, a novel regulatory circuit that modulates conjugation of the IncHI plasmids. Mol. Microbiol. 94(5). 1146-1161.

Giwercman B., Jensen E. T., Hoiby N., Kharazmi A., and Costerton J. W. 1991. Induction of $\beta$ Lactamase production in Pseudomonas aeruginosa biofilm. Antimicrob. Agents Chemother. 35(5), 1008-1010.

Goessweiner-Mohr N., Arends K., Keller W., and Grohmann E. 2014. Conjugation in gram negative bacteria. Microbiol Spectrum. 1-19

Greated A., Lambertsen L., Williams P. A., and Thomas C.M. 2002. Complete sequence of the IncP-9 TOL plasmid pWW0 from Pseudomonas putida. Environ. Microbiol. 4(12), 856-871.

Greendyke R. and Byrd T. F. 2008. Differential antibiotic susceptibility of Mycobacterium abscessus variants in biofilms and macrophages compared to that of planktonic bacteria. Antimicrob. Agents Chemother. 52 (6), 2019-26.

Greulich P., Scott M., Evans M. R., and Allen R. J. 2015. Growth-dependent bacterial susceptibility to ribosome-targeting antibiotics. Mol. Syst. Biol. 11, 796.

Hahn F. E. and Sarre S. G. 1969. Mechanism of action of gentamicin. J. Infect. Dis. 119 (5), 364369.

Hanberger H., Edlund C., Furebring M. et al. and Swedish reference group for antibiotics (SRGA). 2013. Rational use of aminoglycosides - Review and recommendations by the Swedish Reference Group for Antibiotics (SRGA). Scand. J. Infect. Dis. 45, 161-175. 
Hancock R. W., Raffle V. J., and Nicas T. I. 1981. Involvement of the outer membrane in gentamicin and streptomycin uptake and killing in Pseudomonas aeruginosa. Antimicrob. Agents Chemother. 19 (5), 777-785.

Hancock R.E.W. 1981. Aminoglycoside uptake and mode of action-with special reference to streptomycin and gentamicin . Effects of aminoglycosides on cells. J. of Antimicrob. Chemother. 8, 429-45.

Hathorn E., Dhasmana D., Duley L., and Ross J. D. C. 2014. The effectiveness of gentamicin in the treatment of Neisseria gonorrhoeae. Syst. Rev. 3, 104-113.

Henry-Stanley M. J., Hess D. J., and Wells C. L. 2014. Aminoglycoside inhibition of Staphylococcus aureus biofilm formation is nutrient dependent. J. Med. Microbiol. 63, 861-869.

Hirsch R., Ternes T., Haberer K., and Kratz K. L. 1999. Occurrence of antibiotics in the aquatic environment. The Science of the Total Environment. 225, 109-118.

Hirt H., Manias D.A., Bryan E.M., Klein J.R., Marklund J.K., Staddon J.H., Paustian M.L., Kapur V., and Dunny G.M. 2005. Characterization of the pheromone response of the Enterococcus faecalis conjugative plasmid pCF10: complete sequence and comparative analysis of the transcriptional and phenotypic responses of pCF10-containing cells to pheromone induction. J. Bacteriol. 187, 1044-1054.

Hoffman L. R., D’Argenio D. A., MacCoss M. J., Zhang Z., Jones R. A., and Miller S. I. 2005. Aminoglycoside antibiotics induce bacterial biofilm formation. Nature. 436, 1171-1175.

Hoiby N., Bjarnsholt T., Givskov M., Molin S., and Ciofu O. 2010. Antibiotic resistance of bacterial biofilms. Int. J. Antimicrob Agents. 35, 322-332

http://medical-dictionary.thefreedictionary.com/Beta+lactamase, retrieved Jan 08, 2017. 
https://www.ec.gc.ca/eblt-tlws/default.asp?lang=En\&n=5F043BD2-1\&offset=6\&toc=show.

https://www.gov.mb.ca/agriculture/environment/soil-management/soil-managementguide/nutrient-management.html (retrieved April 11, 2017)

https://www.ncbi.nlm.nih.gov/genome, retrieved on Sep 27, 2017.

Huang C. Y., Hsieh S. P., Kuo P.A., Jane W. N., Tu J., Wang Y. N., and Ko C.H. 2013. Impact of disinfectant and nutrient concentration on growth and biofilms formation for a Pseudomonas strain and the mixed cultures from a fine paper machine system. Int. Biodeterioration Biodegrad. 63, 998-1007.

Ikuma K. and Gunsch C. K. 2012. Functionality of the TOL plasmid under varying environmental conditions following conjugal transfer. Appl. Microbiol. Biotechnol. 97(1), 395408.

Jalajakumari M. B. and Manning P. A. 1989. Nucleotide sequence of the traD region in the Escherichia coli F sex factor. Gene. 81, 195-202.

Jana S. and Deb J. K. 2006. Molecular understanding of aminoglycoside action and resistance. Appl. Microbiol. Biotechnol. 70 (2), 140-150.

Johnsen A., Hausner M., Schnell A., and Wuertz S. 2000. Evaluation of fluorescently labelled lectins for noninvasive localization of extracellular polymeric substances in Sphingomonas biofilms. Appl. Environ. Microbiol. 66 (8), 3487-3491.

Jorgensen J. H. and Ferraro M. J. 2009. Antimicrobial susceptibility testing: a review of general principles and contemporary practices. Clin. Infect. Dis. 49, 1749-1755. 
Jussila M. M., Zhao J., Suominen L., and Lindstróm, K. 2007. TOL plasmid transfer during bacterial conjugation in vitro and rhizoremediation of oil compounds in vivo. Environ. Pollut. $146,510-524$.

Kadurugamuwa J.L., Clarke A.J., and Beveridge T.J. 1993. Surface action of gentamicin on Pseudomonas aeruginosa. J. Bacteriol. 175(18), 5798-5805.

Karthikeyan K.G. and Meyer M. T. 2005. Occurrence of antibiotics in wastewater treatment facilities in Wisconsin, USA. Sci. Total Environ. 361, 196- 207

Kelman Z. and O’Donnell M. 1995. DNA polymerase III holoenzyme: structure and function of a chromosomal replicating machine. Annu. Rev. Biochem. 64, 171-200.

Kolleff M. H., Shorr A., Tabak Y.P., Gupta V., Liu L. Z., and Johannes R. S. 2005.

Epidemiology and outcomes of health-care-associated pneumonia: results from a large US database of culture-positive pneumonia. Chest, 128, 3854-3862.

Kolter R., SiegeIe D. A., and Torma A. 1993. The stationary phase of the bacterial life cycle. Annu. Rev. Microbiol. 47, 855-874.

Król J. E., Nguyen H. D., Rogers L. M., Beyenal H., Krone S. M., and Top E. M. 2011. Increased transfer of a multidrug resistance plasmid in Escherichia coli biofilms at the air-liquid interface. Appl. Environ. Microbiol. 77(15), 5079-5088.

Laureti L., Matic I., and Gutierrez A. 2013. Bacterial responses and genome instability induced by subinhibitory concentrations of antibiotics. Antibiotics. 2, 100-114.

Lawley T.D., Gordon G.S., Scott A., Wright D., and Taylor D.E. (2002). Bacterial conjugative transfer: visualization of successful mating pairs and plasmid establishment in live Escherichia coli. Mol Microbiol. 44, 947-956. 
Licht T. R., Christensen B. B. Krogfelt K. A., and Molin S. 1999. Plasmid transfer in the animal intestine and other dynamic bacterial populations: the role of community structure and environment. Microbiology.145, 2615-2622.

Lilly J. and Camps M. 2015. Mechanisms of theta plasmid replication. Microbiol. Spectr. 3(1), $1-18$.

Lister P.D., Wolter D. J., and Hanson N. D. 2009. Antibacterial-resistant Pseudomonas aeruginosa: clinical impact and complex regulation of chromosomally encoded resistance mechanisms. Clin. Microbiol. Rev. 22(4), 582-610.

Ma H. and Bryers J. D. 2012. Non-invasive determination of conjugate transfer of plasmids bearing antibiotic-resistance genes in biofilm-bound bacteria: effects of substrate loading and antibiotic selection. Appl. Microbial. Biotechnol. 97, 317-328.

Madsen J. S. Burmolle M., Hansen L. H., and Sorensen J. 2012. The interconnection between biofilm formation and horizontal gene transfer. FEMS Immunol. Med. Microbiol. 65, 183-195.

Magnet S. and Blanchard J. S. 2005. Molecular insights into aminoglycoside action and resistance. Chem. Rev. 105, 477-497.

Maneewannakul K., Kathir P., and Ippen-Ihler K.1992. Characterization of the F plasmid mating aggregation gene traN and of a new F transfer region locus trbE. J. Mol. Biol. 225, 299-311.

Maneewannakul K., Maneewannakul S., and Ippen-Ihler K. 1993. Synthesis of F pilin. J. Bacteriol. 175, 1384-1391.

Merkey B. V., Lardon L. A., Seoane J. M., Kreft J. U., and Smets B. F. 2011. Growth dependence of conjugation explains limited plasmid invasion in biofilms: an individual-based modelling study. Environ. Microbiol. 13(9), 2435-2452. 
Mingeot-Leclercq M.P. and Tulkens P. M. 1999. Aminoglycosides: Nephrotoxicity. Antimicrob Agents Chemother. 43(5), 1003-12.

Mingeot-Leclercq M.P., Glupczynski Y., and Tulkens P.M. 1999. Aminoglycosides: Activity and Resistance. Antimicrob Agents Chemother. 43 (4), 727-37.

Molin S. and Tolker-Nielsen T. 2003. Gene transfer occurs with enhanced efficiency in biofilms and induces enhanced stabilisation of the biofilm structure. Curr. Opin. Biotechnol. 14, 255-261.

Molina L., Udaondo Z., Duque E., Fernandez M., Bernal P., Roca A., Torre J. de la, and Ramos J. L. 2016. Specific gene loci of clinical Pseudomonas putida isolates. PLOS one. 11(1), 1-24.

Molina L., Udaondo Z., Duque E., Fernandez M., Molina-Santiago C., Roca A., Porcel M., Torre J., Segura A., Plesiat P., Jeannot K., and Ramos J. L. 2014. Antibiotic resistance determinants in a Pseudomonas putida strain isolated from a hospital. PLOS one. 9 (1), 81604.

Monem A. M., Taucher-Scholz G., and Klinkert M. Q. 1983. Identification of Escherichiacoli DNA helicase I as the traI gene product of the F sex factor. Proc Natl. Acad Sci. 80, 4659-4663.

Moore, D., Wu J. H., Kathir P., Hamilton C. M., and Ippen-Ihler K. 1987. Analysis of transfer genes and gene products within the traB-traC region of the Escherichia coli fertility factor, F. J. Bacteriol. 169, 3994-4002.

Moritz V., Julian B., and Miriam H. 2017. Validation of reference genes for RT-qPCR in marine bivalve ecotoxicology: Systematic review and case study using copper treated primary Ruditapes philippinarum hemocytes. Aquatic Toxicology. 185, 86-94.

Muela A., Pocino M., Arana I., Justo J. I., Irreberi J., and Barcina I. 1994. Effect of growth phase and parental cell survival in River water on plasmid transfer between Escherichia coli Strains. Appl. Environ. Microbiol. 60, 4273-4278. 
Neda M., Hamid A., Mohammad J. G, Masoude K., and Ehsanollah G. 2015. Application of Reverse Transcriptase -PCR (RT-PCR) for rapid detection of viable Escherichia coli in drinking water samples. Journal of Environmental Health Science \& Engineering. 13 (24), 1-6.

Normander B., Christensen B. B., Molin S., and Kroer N. 1998. Effect of bacterial distribution and activity on conjugal gene transfer on the phylloplane of the bush bean (Phaseolus vulgaris). Appl. Environ. Microbiol. 64, 1902-1909.

Novotny C. P. and Fives-Taylor P. 1974. Retraction of F pili. J. Bacteriol. 117, 1306-1311.

Novotny C. P. and Lavin K. 1971. Some effects of temperature on the growth of F pili. J. Bacteriol. 107, 671-682.

Panicker M. M. and Minkley E. 1992. Purification and properties of the F sex factor TraD protein, an inner membrane conjugal transfer protein. The Journal of Biological Chemistry. 267(18), 12761-12766.

Park W., Jeon C. O., Hohnstock-Ashe A. M., Winans S. C., Zylstra G. J., and Madsen E. L. 2003. Identification and characterization of the conjugal transfer region of the $\mathrm{pCg} 1$ plasmid from naphthalene-degrading Pseudomonas putida Cg1. Appl. Environ. Microb. 69(6), 32633271.

Paul M. Tulkens and Francoise Van Bambeke. 2007. Combined effect of pH and concentration on the activities of gentamicin and oxacillin against Staphylococcus aureus in pharmacodynamic models of extracellular and intracellular infections. J. Antimicrob. Chemother. 59, 246-253.

Pei R. and Gunsch C.K. 2009. Plasmid conjugation in an activated sludge microbial community. Environ. Eng. Sci. 26, 825-831. 
Pfaffl M. A. 2001. A new mathematical model for relative quantification in real time RT PCR. Nucleic acids research. 29 (9), 2003-2007.

Postelnik F. 2012. Examining plasmid transfer of pJP4 in a mixed community biofilm formed in a microcosm simulating a porous aquifer, Ryerson university, 1-109.

Popa O., Covo E. Z., Landan G., Martin W., and Dagan T. 2011. Directed networks reveal genomic barriers and DNA repair bypasses to lateral gene transfer among prokaryotes. Genome Res. 21, 599-609.

Ramsay J. P., Kwong S. M., Murphy R. J.T., Eto K. Y., Price K.J., Nguyen Q.T., O’Brien F.G., Grubb W.B., Coombs G.W., and Firth N. 2016. An updated view of plasmid conjugation and mobilization in Staphylococcus. Mob. Genet. Elements. 6(4), 1208317(1-11).

Rasamiravaka T. and Jaziri M. El. 2016. Quorum sensing mechanisms and bacterial response to antibiotics in P. aeruginosa. Curr. Microbiol. 73, 747-753.

Reisner A., Holler B. M., Molin S., and Zechner E. L. 2006. Synergistic effects in mixed Escherichia coli biofilms: conjugative plasmid transfer drives biofilm expansion. J. Bacteriol. 188, 3582-3588.

Rittmann B. E., Smets B. F., MacDonald J. A., and Stahl D. A. 1995. Plasmid transfer for enhancing degradation capabilities. Environ. Health Perspect. 103, 113-115.

Romero D., Traxler M. F., Lopez1 D., and Kolter R. 2011. Antibiotics as signal molecules. Chem. Rev. 111(9), 5492-5505.

Ruiz-Masó J. A., Machón C., Bordanaba-Ruiseco L., Espinosa M., Coll M., and del Solar G. 2015. Plasmid rolling circle mechanism. Microbiol. Spectrum. 3(1), 1-24. 
Salcedo D. E., Lee J. H., Hab U. H., and Kim S. P. 2015. The effects of antibiotics on the biofilm formation and antibiotic resistance gene transfer. Desalination and Water Treatment. 54, 35823588.

Sauer K., Camper A.K., Ehrlich G.D., Costerton J. W., and Davies D.G. 2002. Pseudomonas aeruginosa displays multiple phenotypes during development as a biofilm. J. Bacteriol. 184(4), 1140-1154.

Schandel K. A., Maneewannakul S., Vonder-Haar R. A., Ippen-Ihler K., and Webster R. E. 1990. Nucleotide sequence of the F plasmid gene, traC and identification of its product. Gene.96,137140.

Scornec H., Bellanger X., Guilloteau H., Groshenry G., and Merlin C. 2017. Inducibility of Tn916 conjugative transfer in Enterococcus faecalis by subinhibitory concentrations of ribosome-targeting antibiotics. J. Antimicrob. Chemother. 72, 2722-2728.

Seier-Petersen M. A., Jasni A., Aarestrup F. M., Vigre H., Mullany P., Roberts A. P., and Agerso Y. 2014. Effect of subinhibitory concentrations of four commonly used biocides on the conjugative transfer of Tn916 in Bacillus subtilis. J. Antimicrob. Chemother. 69, 343-348.

Selimoglu E. 2007. Aminoglycoside-Induced Ototoxicity. Curr. Pharm. Des. 13, 119-126.

Sepulveda E., Vogelmann J., and Muth G. 2011. A septal chromosome segregator protein evolved into a conjugative DNA-translocator protein. Mob. Genet. Elements. 1, 225-229.

Seoane J., Yankelevich T., Dechesne A., Merkey B., Sternberg C., and Smets B.F. 2011. An individual-based approach to explain plasmid invasion in bacterial populations. FEMS Microbiol. Ecol. 75, 17-27. 
Shamsad F. 2012. Transfer of catabolic plasmid pJP4 in biofilms in a flow through chamber. Ryerson university. 1-121.

Shamsad F. and Hausner M. 2018. Effect of cell growth phases on transconjugant formation in plate matings and biofilms. Microbiologyopen-submitted.

Silverman P. M., 1997. Towards a structural biology of bacterial conjugation. Mol. Microbiol. 23(3), 423-429.

Smets B. F, Rittmann B. E., and Stahl D. A. 1993. The specific growth rate of Pseudomonas putida PAW1influences the conjugal transfer rate of the TOL plasmid. Appl. Environ. Microbiol. 59 (10), 3430-3437.

Smith E. K. and Prairie Y. T. 2004. Bacterial metabolism and growth efficiency in lakes: The importance of phosphorus availability. Limnol. Oceanogr. 49(1), 137-147.

Solar G. D., Giraldo R., Ruiz-Echevarria M. J., Espinosa M., and Diaz-Orejas. 1998. Replication and control of circular bacterial plasmids. Microboil. Mol. Biol. Rev. 62(2), 434-464.

Sorek R., Zhu Y. W., Creevey C. J., Francino M. P., Bork P., and Rubin, E. M. 2007. S. Science. 318, 1449.

Spoering A. L. and Lewis K. 2001. Biofilms and planktonic cells of Pseudomonas aeruginosa have similar resistance to killing by antimicrobials. J. of Bacteriol. 183 (23), 6746-6751.

Stewart F. J. 2013. Where the genes flow. Nat. Geosci. 6, 688-690.

Stewart P. S. 2002. Mechanisms of antibiotic resistance in bacterial biofilms. Int. J. Med. Microbiol. 292, 107-13. 
Sudarshana P. and Knudsen G. R. 1995. Effect of parental growth on dynamics of conjugative plasmid transfer in the pea spermosphere. Appl. Environ. Microbiol. 61(8), 3136-3141.

Sun F., Qu F., Ling Y., Mao P., Xia P., Chen H., and Zhou D. 2013. Biofilm-associated infections: antibiotic resistance and novel therapeutic strategies, Future Microbiol. 8 (7), 877-86.

Takei S., Hotomi M. and Yamanaka N. 2013. Minimal biofilm eradication concentration of antimicrobial agents against nontypeable Haemophilus influenzae isolated from middle ear fluids of intractable acute otitis media. J. Infect. Chemother. 19, 504-509.

Thoma L. and Muth G. 2016. Conjugative DNA transfer in Streptomyces, a mycelial organism. Plasmid. 87 (88), 1-9.

Thomas C. M. and Nielsen K. M. 2005. Mechanisms of, and barriers to, horizontal gene transfer between bacteria. Nature Rev. 3, 711-721.

Thomas C. M. and Smith C. A. 1987. Incompatibility group P plasmids: Genetics, evolution, and use in genetic manipulation. Ann. Rev. Microbiol. 41, 77-101.

Top E. M. and Springael D. 2003. The role of mobile genetic elements in bacterial adaptation to xenobiotic organic compounds. Curr. Opin. Biotechnol. 14, 262-269.

Trevors J. T. 2011. Viable but non-culturable (VBNC) bacteria: Gene expression in planktonic and biofilm cells. J. Microbiol. Meth. 86, 266-273.

Uddin M.B. 2014. Conjugative transfer of plasmid pJP4 in biofilms and catabolic activity of transconjugant, Ryerson University. 1-106.

Velappan N., Sblattero D., Chasteen L., Pavlik P., and Bradbury A. R. M. 2007. Plasmid incompatibility: more compatible than previously thought?. Protein Eng. Des. Sel. 20, 309-313. 
Wallden K., Rivera-Calzada A., and Waksman G. 2010. Type IV secretion systems: versatility and diversity in function, Cell. Microbiol. 12(9), 1203-1212.

Walters M. C. III, Roe F., Bugnicourt A., Franklin M. J., and Stewart P. S. 2003. Contributions of antibiotic penetration, oxygen limitation, and low metabolic activity to tolerance of Pseudomonas aeruginosa biofilms to ciprofloxacin and tobramycin. Antimicrob. Agents Chemother. 47, 317-323.

Werhli W. 1983. Rifampin: mechanisms of action and resistance. Rev. Infect. Dis. 5, S407-S410.

Willey J. M., Sherwood L. M., and Woolverton C. J. 2011. Prescott's microbiology ( $8^{\text {th }}$ edition), McGraw Hill, New York. 382-384.

Wirth R. 1994. The sex pheromone system of Enterococcus faecalis more than just a plasmidcollection mechanism. Eur. J. Biochem. 222, 235-246.

Wong J. J. W, Lu J., and Glover J. N. M. 2012. Relaxosome function and conjugation regulation in F-like plasmids - a structural biology perspective. Mol. Microbiol. 85(4), 602-617.

Xia Z. J., Wang J., Hu W., Liu H., Gao X. Z., Wu Z. H., Zhang P. Y., and Li Y. Z. 2008. Improving conjugation efficacy of Sorangium cellulosum by the addition of dual selection antibiotics. J. Ind. Microbiol. Biotechnol. 10, 11157-11163.

Yamamoto M., Kanegasaki S., and Yoshikawa M. 1981. Role of membrane potential and ATP in complex formation between Escherichia coli male cells and filamentous phage fd. J. Gen. Microbiol. 123, 343-349.

Yin X. and Stotzky G. 1997. Gene transfer among bacteria in natural environments. Adv. Appl. Microbiol. 45, 153-212. 
Zhang P. Y., Xu P. P., Xia Z. J., Wang J., Xiong J., and Li Y. Z. 2013. Combined treatment with the antibiotics kanamycin and streptomycin promotes the conjugation of Escherichia coli. FEMS Microbiol Lett. 348, 149-156. 